OAK RIDGE NATIONAL LABORATORY

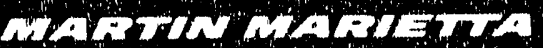

\section{Status Report \\ A Hydrologic Framework for the Oak Ridge Reservation}

\author{
D. K. Solomon \\ G. K. Moore \\ L. E. Toran \\ ค. B. Dreier \\ W. M. McMaster
}

Environmental Sciences Division

Publication No. 3815 
This report has been reproduced directly from the best available copy.

Available to DOE and DOE contractors from the Office of Scientific and Technical Information, P.O. Box 62, Oak Ridge, TN 37831; prices available from (615) 576-8401, FTS 626-8401.

Availabte to the public from the National Tochnical Information Service, U.S. Department of Commerce, 5285 Port Royal Rd., Springfield, VA 22161.

This report was prepered as an account of work sponsored by an agency of the United States Government. Neither the United States Government nor any agency thereot, nor any of their employees, makes any warranty, express or implied, or assumes any legal liability or responsibility for the accuracy, cont. phateness, or usefuiness of any information, apparatus, product, or process disclosed, or represents that its use would not infringe privately owned righits. Reference herein to any specific commercial product, process, or service by trade neme, trademark, manufacturer, or othenwise, does not necessarily constitute or imply its endorsement, recommendetion, or fevoring by the United States Government or any apency thereof. The views and opinions of authors expressed herein do not necessarly state or reflect those of the United States Government or any agency thereot. 


\section{STATUS REPORT}

\section{A HYDROLOGIC FRAMEWORK FOR THE}

\section{OAK RIDGE RESERVATION}

D. K. Solomon, G. K. Moore, ${ }^{1}$ L. E. Toran, R. B. Dreier, and W. M. McMaster'

Environmental Sciences Division

Publication No. 3815

1Department of Civil Engineering, The University of Tennessee, Knoxville.

ENERGY SYSTEMS OAK RIDGE HYDROLOGY SUPPORT PRDGRAM

(Activity No. 264502000 )

May 1992

Prepared for the

Energy Systems Groundwater Program Office

Prepared by the

OAK RIDGE NATIONAL LABORATORY

Oak Ridge, Tennessee 37831

managed by

MARTIN MARIETTA ENERGY SYSTEMS, INC.

for the

U.S. Department of Energy

under contract DE-AC05-84OR21400

NOTICE: This document contains information of a preliminary nature. It is subject to revision or correction and therefore does not represent a final report. 


\section{Author Affiliations}

D. K. Solomon, Leader, Groundwater Hydrology Group, Laura Toran, research associate, and RaNaye Dreier, Leader, Geology and Geophysics Group, are with Martin Marietta Energy Systems, Earth and Atmospheric Sciences Section, Environmental Sciences Division, Oak Ridge National Laboratory. G. K. Moore and W. M. McMaster are research associates with the Civil Engineering Department at The University of Tennessee, Knoxville. 


\section{CONTENTS}

Page

LIST OF FIGURES . . . . . . . . . . . . . . . . . . . . vii

LIST OF TABLES . . . . . . . . . . . . . . . . . ix

FOREWORD ........................ . . . . . . .

ACKNOWLEDGMENTS ................... xiii

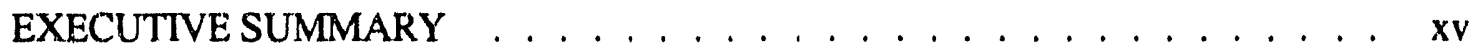

1. INTRODUCTION . . . . . . . . . . . . . . . . . 1-1

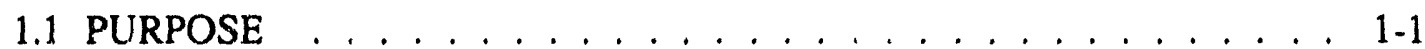

1.2 PROGRAMMATIC BACKGROUND ............... . . . . . .

1.3 OVERVIEW OF DOCUMENT . . . . . . . . . . . . . . . . 1-2

1.4 IMPLICATIONS OF SCALE . . . . . . . . . . . . . . . . . . . 1-3

1.5 HYDROLOGIC AND GEOLOGIC SETTING . . . . . . . . . . . . . . 1.5

1.5.1 General Hydrology . . . . . . . . . . . . . . . . . . . . 1-5

1.5.2 Physiography ... . . . . . . . . . . . . . . . . 1-5

1.5 .3 Geology . . . . . . . . . . . . . . . . . . . 1-6

2. OVER VIEW OF THE CONCEPTUAL MODEL . . . . . . . . . . . . . . . 2-1

2.1 STORMFLOW ZONE . . . . . . . . . . . . . . . . . . 2-3

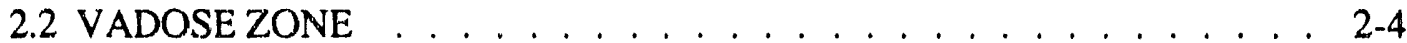

2.3 GROUNDWATER ZONE . . . . . . . . . . . . . . . . . . . . . . . . 2-4

2.4 AQUICLUDE . . . . . . . . . . . . . . . . . . . . 2-7

3. SYSTEM PROPERTIES . . . . . . . . . . . . . . . . . 3-1

3.1 CHARACTERISTICS OF HYDROLOGIC ZONES. . . . . . . . . $3-4$

3.1.1 Characteristics of the Stormflow Zone . . . . . . . . . . . . . . 3-5

3.1.2 Characteristics of the Vadose Zone . . . . . . . . . . . . . . . . 3-13

3.1.3 Characteristics of the Groundwater Zone . . . . . . . . . . . . . . 3-17

3.1.4 Characteristics of the Aquiclude . . . . . . . . . . . . . . . . . . . . . 3-29

3.2 CHEMICAL CHARACTERISTICS . . . . . . . . . . . . 3-29

3.2.1 Chemical Characteristics of Water in the Stormflow Zone . . . . . . 3-30

3.2.2 Chemical Characteristics of Water in the Groundwater Zone . . . . . 3-31

3.2.3 Sorption Properties of Soil and Rock . . . . . . . . . . . . . . . 3-37

4. SUMMARY, CONCEPTS OF FLOW . . . . . . . . . . . . . . . . . . . . 4-1 


\section{CONTENTS (continued)}

5. IMPLICATIONS TO ENVIRONMENTAL RESTORATION AND

MONITORING AND TO WASTE MANAGEMENT . . . . . . . . . . . 5-1

5.1 SURFACE WATER . . . . . . . . . . . . . . . . . . 5-1

5.2 STORMFLOW ZONE . . . . . . . . . . . . . . . . . . 5-3

5.3 VADOSE ZONE ................... . . . . . . . . .

5.4 GROUNDWATER ZONE . . . . . . . . . . . . . . . . . . 5-3

5.5 TRANSPORT PROCESSES . . . . . . . . . . . . . . . . . 5-5

5.6 GENERAL IMPLICATIONS . . . . . . . . . . . . . . . . 5 .7

6. RECOMMENDATIONS FOR FURTHER

INVESTIGATIONS . . . . . . . . . . . . . . . . . 6-1

6.1 GENERAL RECOMMENDATIONS. . . . . . . . . . . . . . . . 6-1

6.2 STORMFLOW ZONE . . . . . . . . . . . . . . . . . . . 6-2

6.3 GROUNDWATER ZONE .................. . . . . . . . .

6.4 RECOMMENDED APPROACHES . . . . . . . . . . . . . . . . 6-3

GLOSSARY OF TERMS . . . . . . . . . . . . . . . . G-1

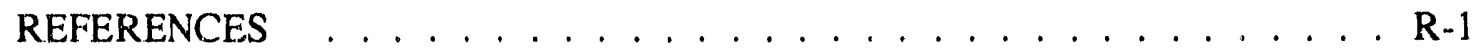




\section{LIST OF FIGURES}

Figure Page

2.1 Schematic vertical relationships of flow zones of the ORR . . . . . . . . . . 2-2

3.1 Definitions of several parameters important in the context of flow and transport in fractured porous media . . . . . . . . . . 3-1

3.2 Relationship among $\mathrm{b}, \mathrm{B}, \mathrm{K}_{\text {bulk, } \text { and } \theta_{\mathrm{e}} \ldots \ldots \ldots \ldots} \ldots \ldots \ldots$

3.3 Locations of stormflow monitoring tubes in the study area in headwaters of Melton Branch . . . . . . . . . . . . . . . . . 3-6

3.4 During the nongrowing season in the Melton Branch watershed, graphs of log water-level stage in the stormflow zone vs time plot as straight lines soon after the hydrograph peaks.

3.5 During the growing season, graphs of water-level recession in the stormflow zone plot as a steepening curve because of water consumption by evapotranspiration . . . . . . . . . . . . . 3-9

3.6 A cumulative probability graph of hydraulic conductivity of the stormflow zone, measured by infiltration tests under saturated conditions, shows a lognormal distribution . . . . . . . . . . . . . 3-10

3.7 $\mathrm{Br}$ concentration observed at a depth of $85 \mathrm{~cm}$ as a function of time . . . . . 3-12

3.8 Storativity determined from aquifer tests is lognormally distributed . . . . . . . 3-18

3.9 A cumulative probability graph of transmissivity data shows two log-normal populations . . . . . . . . . . . . . . . . . 3-20

3.10 Straddle packer test results from boreholes collared in the Chickamauga aquitard

3.11 Schematic cross-section showing very generalized flow paths, related geochemical evolution, and relative flow rates .

3.12 Deurerium vs 180 for groundwater and rainwater samples collected on the ORR and their relationship to the meteoric water line . . . . 3-36

3.13 Approximate order of magnitude of laboratory-measured sorption coefficients $(\mathrm{Kd})$ and calculated retardation factors $(\mathrm{R})$ for selected radionuclides and calcium and soil and rock materials of the ORR 


\section{LIST OF TABLES}

Table

Page

1.1 Geologic units of the Oak Ridge Reservation . . . . . . . . . . . . . 1-7

3.1 Summary of measured hydraulic conductivity values for the intermediate and deep interval, Bear Creek, Bethel, and Melton valleys . . . . . . . . 3-25

3.2 Chemical constituents and physical properties of groundwater from wells $<165 \mathrm{~m}$ deep near ORNL and the $\mathrm{Y}-12$ Plant . . . . . . . . 3-32

3.3 Approximate relationship among depth, flow interval, and water type for ORR aquitards ................ . . . . . . . . . .

4.1 Concepts of groundwater flow and contaminant transport on the Oak Ridge Reservation . . . . . . . . . . . . . . . . . . . . . 


\section{FOREWORD}

The conceptual hydrologic framework for the Oak Ridge Reservation is still evolving. The description of the framework in this status report represents the best current thinking on the properties and processes affecting contaminant migration in an extremely complicated setting. Confidence in the general framework is high, but a number of as yet unproved, and thus conjectural, assertions are made. These are not made to mislead the reader but to catalyze the further identification and investigation of properties and processes believed to be keys to quantifying contaminant transport. 


\section{ACKNOWLEDGMENTS}

The authors are especially grateful to Dr. Stanley N. Davis, Department of Hydrology and Water Resources, University of Arizona, for his constructive and supportive review of the concepts presented here and of plans for future work.

The authors appreciate Dick Ketelle's additions to the description of flow in the vadose zone of the Knox aquifer, Sect. 3, and Steve Haase's contribution to the description of the aquiclude, Sect. 3.

The authors thank the reviewers for their thoughtful and useful recommendations for improvement: Dale Huff and Ellen Smith, ORNL Environmental Sciences Division, primary reviewers; Roger Clapp, Steve Haase, Bob Luxmoore, Jon Nyquist, and John Trabalka, ORNL Environmental Sciences Division; and Paul Baxter and Mark Tardiff, ORNL Office of Environmental Compliance. 


\section{EXECUTIVE SUMMARY}

This first status report on the Hydrologic Studies Task of the Oak Ridge Reservation Hydrology and Geology Study (ORRHAGS) revises earlier concepts of subsurface hydrology and hydrogeochemistry of the ORR. A new classification of hydrogeologic units is given, as well as new interpretations of the hydrogeologic properties and processes that influence contaminant migration. The conceptual hydrologic framework introduced in this report is based primarily on reinterpretations of data acquired during earlier hydrologic investigations of waste areas at and near the three U.S. Department of Energy Oak Ridge (DOE-OR) plant facilities. In addition to describing and interpreting the properties and processes of the groundwater systems as they are presently understood, this report describes surface water-subsurface water relations, influences on contaminant migration, and implications to environmental restoration, environmental monitoring, and waste management.

\section{Some Implications to Environmental Restoration, Environmental Monitoring, and Waste Management}

The understanding of hydrogeologic properties and processes, as briefly summarized later, is important because of implications to environmental management on the ORR. Some practical conclusions are evident:

With few exceptions, groundwater discharges within the ORR presently meet drinking water standards.

The restoration of contaminated groundwater of the ORR to pristine quality is not a technologically realistic goal. One major reason for this is that transport processes in the subsurface-diffusion from fractures to the rock matrix, sorption, and exchange-have resulted in an accumulation of contaminants downgradient of the sources. The flushing of these contaminants and eventual retum of water to the original quality could require time periods on the order of centuries; the time frame and end result will not be much different, whether by natural processes or if remedial technology is applied.

The use of wells for the monitoring of contaminant migration from waste areas on the ORR is unreliable and may produce misleading results, although such monitoring has limited value for assessing general water quality at specific locations. Most groundwater travels to 
nearby streams through the uppermost part of the groundwater zone. Contaminants in the subsurface at waste areas are discharged to local surface streams; it is more valid to monitor surface-water quality and contaminant load than wells in order to characterize contaminant mass flow.

Effective surface-water-contaminant monitoring systems must be established. One basis for system design would be the identification of the discrete points at which contaminants are discharged to surface drainageways.

Waste area groupings on the ORR occupy relatively large areas, but contaminant discharge to streams occurs only at a few distinct and identifiable points, such as seeps. The characteristics of flow pains must be understood well enough to enable tracking along pathways from known points of surface discharge to locations of discrete contaminant sources in waste burial areas. This information would then be used in designing remedial measures for hydrologic isolation of the source. In the case of buried wastes, a relatively sinall number of concentrated sources are very likely the origin of most contaminant flux. Thus, remedial actions in waste burial areas should focus on the area containing the concentrated source rather than on waste-area-wide remedial actions.

Transport processes effectively buffer migration of contaminants in the subsurface. An instantaneous release of contaminants from a primary source, such as from the failure of a container, does not result in an immediate loading to streams. Transport processes must be quantified to allow prediction of lag time between peak contaminant release at the source to peak contaminant release to the stream. This also is essential for accurate estimation of time required before effects of corrective actions will be observed. Sorption and exchange are weak processes in the case of some contaminants, but matrix diffusion significantuy alters the rate of flux of all contaminants.

Although transport processes have significantly attenuated and buffered past contaminant releases from waste areas, thiy have resulted in secondary contaminant sources along flow pathways. These secondary sources could, in the case of older waste areas, contain more contaminants (at lower concentrations) than the original site now contains. Contaminants are transported off the ORR by surface water rather than by groundwater. Significant contaminant movement and discharge take place during periods of high runoff. 
Deep flow of groundwater off the ORR, such as under the Clinch River, if it occurs, does not endanger groundwater supplies outside the ORR because or long paths, slow travel times, and relative isolation from contaminant sources.

Given that (1) virtually all contartinated groundwater from waste areas underlain by aquitards (see below) is discharged to local surface streams within the ORR and (2) groundwater restoration is not a practical altemative, engineering feasibility studies should be undertaken for treatment of surface water at points where contaminant-bearing streams leave the ORR. On the other hand, some flow paths from waste areas underlain by the Knox aquifer, as described below, may discharge to the surface at points beyond the ORR boundary.

\section{Basic Conceptual Framework}

Geologic units of the ORR are assigned to two broad hydrologic groups: (1) the Knox aquifer-formed by the Knox Group and the Maynardville Limestone--in which flow is dominated by solution conduits and which stores and transmits relatively large volumes of water and (2) the ORR aquitar.s-made up of all other geologic units of the ORR--in which flow is controlled by fractures, and which may store fairly large volumes, but transmit only limited anounts of water.

In the vertical, both the Knox aquifer and the ORR aquitards are divided into the following:

- The stormfiow zone, a thin region at the surface in which transient, precipitationgenerated flow accounts for an estmated $90 \%$ or more of the water moving through the subsurface. This zone is a major pathway for transporting cortaminants from the subsurface to the surface.

- The vadose zone is a mostly unsaturated zone above the water table.

- The groundwater zone, which is continuously saturated, is the region in which most of the remaining $10 \%$ of subsurface flow occurs.

- The aquiclude is a zone in which witer movement, if if occurs, probably is on a geologic time scale.

Flow in the aquitards is shallow; $-98 \%$ is to depths of $<30 \mathrm{~m}$. Water in the aquitards travels along flow paths having lengths of tens to a few hundred meters before being discharged to local surface drainageways. Water in the aquitards is at best a marginal 
resource. A typical well 'yrelds $<0.02 \mathrm{~L} / \mathrm{s}\left(0.25 \mathrm{gal} / \mathrm{mir}^{\prime}\right.$; in many places, wells are incapable of producing domestic quantities of water. Groundwater flow volume decreases and solute residence times increase sharply with depth. Mean solute transport rate in the stormflow zone is on the order of meters per hour, but in the intermediate and deep intervals of the groundwater zone, representative transport rates are as low as a few centimeters per year. In the vertical, most groundwater flow in the aquitards occurs through a few widely spaced $(7-50 \mathrm{~m})$ permeable regicns.

The Knox aquifer is the only true aquifer of the ORR and is the primary source of sustained natural flow in perennial streams such as upper Whiteoak Creek, Walker Branch, Scarboro Creek, East Fork Poplar Creek, and Bear Creek. In some places the Knox aquifer can supply large quantities of water to wells. Flow volumes are significantly larger than in the aquitards, and flow paths are deeper. The potential groundwater flow path length in the Knox aquifer is substantially greater than in the aquitards-on the order of kilometers rather than tens of meters or a few hundred meters. The one strongly suspected instance of groundwater flow across the ORR boundary occurs along Chestnut Ridge, where water from the Knox aquifer travels $>2.5 \mathrm{~km}$ and discharges to Scarboro Creek.

There is no evidence of contaminant migration along deep, long subsurface flow paths. Virtually all mobile water in the aquitards is discharged to local streams within the ORR. However, it is likely that some flowpaths in the Knox aquifer lead to discharge points outside the ORR boundary.

Residence times of solutes near the water table in the aquitards range from a few days to a few years. In the inter nediate and deep intervals, estimates of residence times derived from ${ }^{14} \mathrm{C}$ measurerrents and modeling are hundreds to tens of thousands of years.

Geochemical processes (adsorption and ion exchange) and the matrix diffusion process significantly alter chemical concentrations of solutes in the ORR groundwater. One result is retardation and storage of any contaminant in the rock matrix.

The conceptual framework is believed to be fundamentally complete and correct. The basic premises are unlikely to change with further findings. Some details remain uncertain, and additional data are necessary to prove and refine some parts of the framework. 


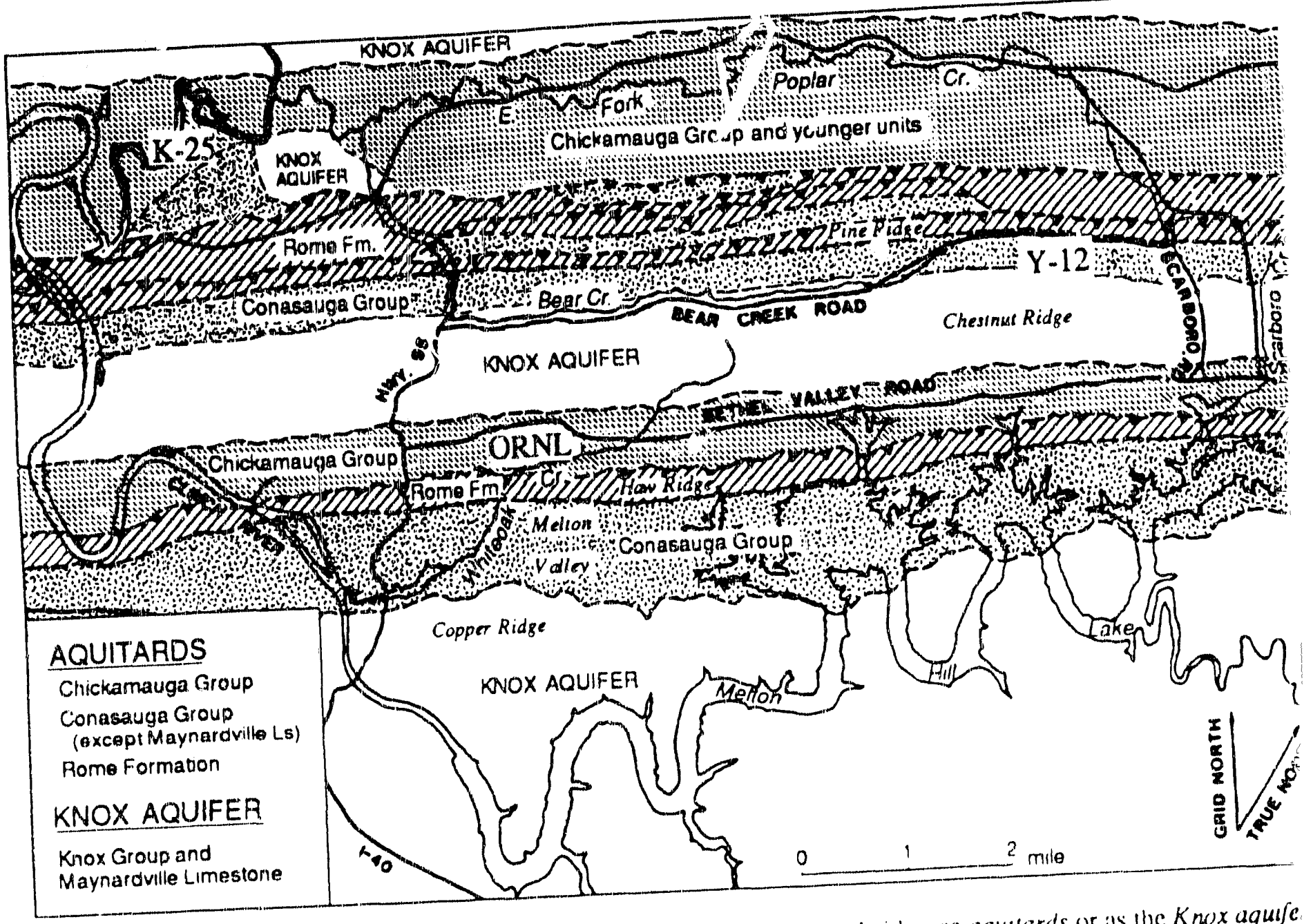

To emphasize the hydrologic contrasts. geologic units of the ORR are grouped either as aquitards or as the Knox aquite shown above,

The aquitards are mosuly fractured shale, siltstone, sandstone, and thinly bedded limestone units that underlie Mclton V are located, and a part of the K-25 area, as well as Haw Rit puitards are formed by fractures in the nearly impermeable rock matrix. The aquitards : Pine Ridge. Flowpaths in the aqu permeability that decteases rapidly with depth and by shallow, short tlowpaths.

fer is mosty massive, siliceous dolomite and limestone that underlies Copper Ridge. Chestnut Ridge, Re $\mathrm{K}-25$ area. In the Knox aquifer, solution cavities form flow conduit systems in the Some flowpaths in the Knox aquifer are as long as $3 \mathrm{~km}$.and are substantially deeper than aquitards. 

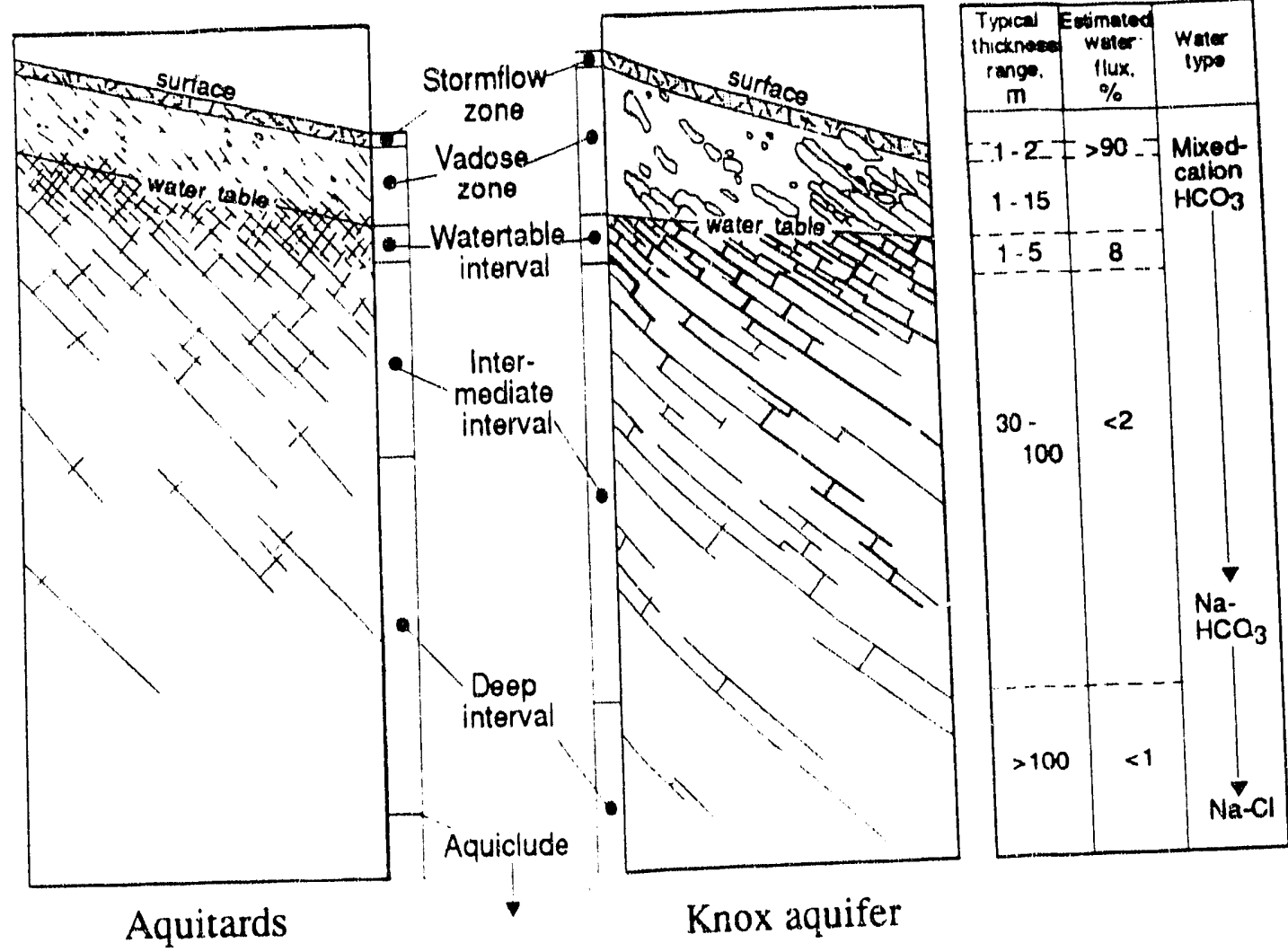

Not to scale

Schematic profile showing subsurface flow zones and intervals, general thickness ranges, estimated relative annual water tlux, and change in water type with depth.

fer, as

'allcy

dge ani

are

snearly

in the

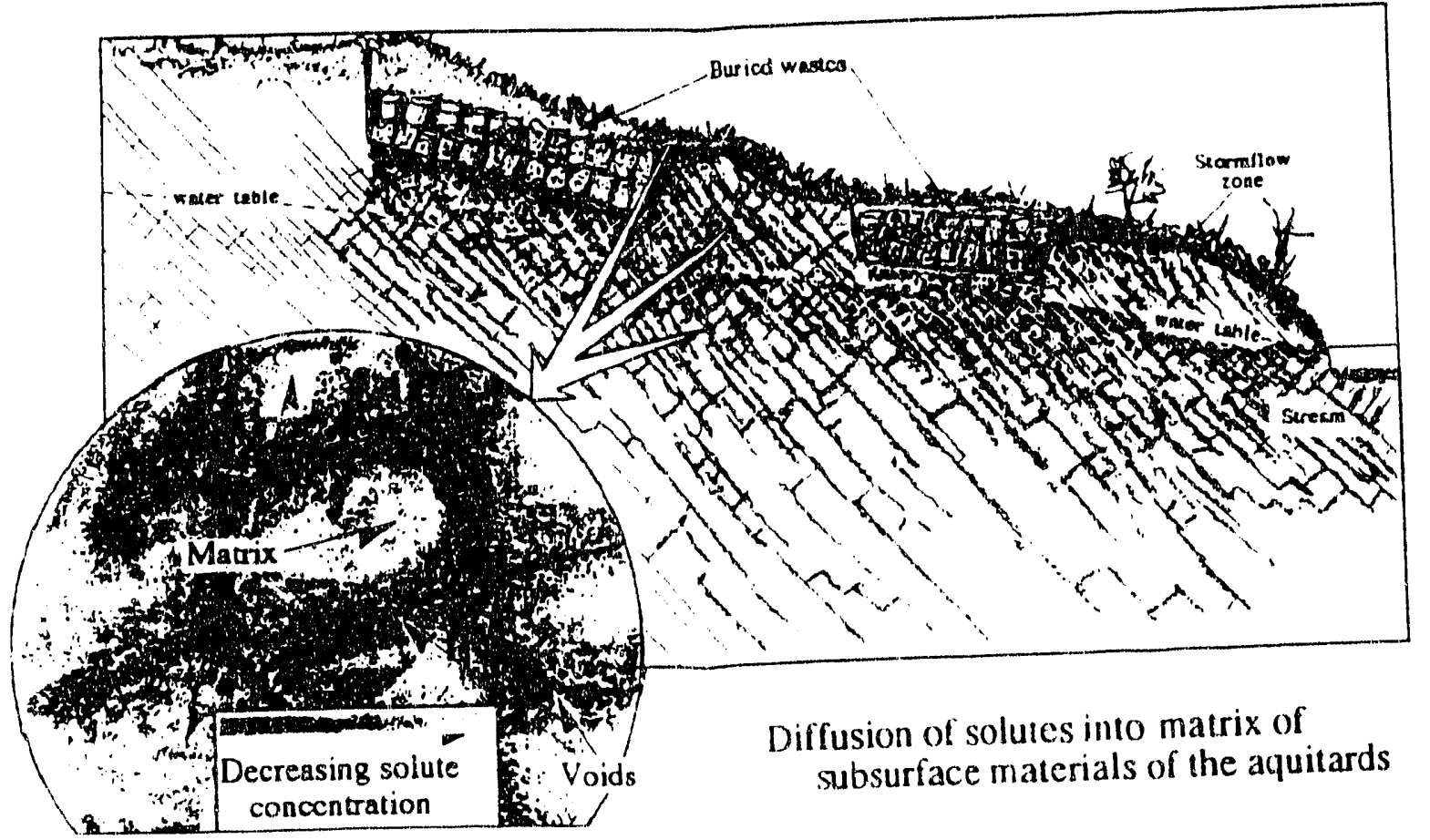




\section{STATUS REPORT}

\section{A HYDROLOGIC FRAMEWORK FOR THE OAK RIDGE RESERVATION}

\section{INTRODUCTION}

\subsection{PURPOSE}

The Oak Ridge Reservation Hydrology and Geology Study (ORRHAGS) was established in 1989 as an integrated study of the hydrology, geology, and soils of the reservation in support of the extensive activities in environmental monitoring, environmental restoration, waste management, and regulatory compliance on the Oak Ridge Reservation (ORR) of the U.S. Department of Energy (DOE).

The Hydrologic Studies Task of ORRHAGS is designed to provide essential information about the hydrologic environment of the ORR to those responsible for dealing with environmental issues, including restoration, environmental monitoring, and waste management, compliance, and enforcement.

In order to ensure optimum environmental protection, these systems and their elements must be better understood and quantified. Additionally, in light of the enormous costs attached to environmental protection, restoration, monitoring, and waste management, these activities must be planned and implemented as efficiently as possible. A practical understanding of the hydrologic systems is reciuired for all the objectives associated with contaminants in the hydrologic environment of the ORR.

This report describes the current status of the development of a workable framework for the hydrology of the ORR. The framework is based mostly on data and information available from previous investigations.

\subsection{PROGRAMMATIC BACKGROUND}

The 35-mile ${ }^{2}$ ORR contains three DOE research and production facilities: The Oak Ridge Y-12 Plant, Oak Ridge National Laboratory, and the Oak Ridge K-25 Site. Groundwater monitoring, site investigations, site characterization, and remedial actions are under way at 
all three facilities to address groundwater contamination that has been identified at multiple sites within each facility. These investigations are site-specific and deal only with the individual contaminated site, or with relatively small groups of sites within each facility.

Prior to the establishment of ORRHAGS, there was no integrated effort to determine largescale hydrologic attributes or the overall groundwater characteristics of the ORR. During 1989 the entire ORR was placed on the U.S. Environmental Protection Agency's (EPA) National Priorities List. In response, a Federal Facilities Agreement has been developed among DOE, EPA Region IV, and the Tennessee Division of Environment and Conservation. Implementation of the terms of the agreement and of DOE Order 5400.1 requires as complete an understanding as possible of the hydrogeologic regimes of the ORR. It was recognized as essential to assemble, develop, and interpret relevant data in order to meet regulatory and related demands in the most efficient and effective manner.

\subsection{OVERVIEW OF DOCUMENT}

This report summarizes progress toward the construction of a practical framework for understanding the hydrogeology of the ORR and it provides evidence and summarizes available data confirming the model. Where evidence is not in accordance with an element of the model, it is identified. The report identifies remaining issues for which there is insufficient evidence or data. The concepts are highlighted in general terms in Sect. 2 and more fully elaborated in Sects. 3 and 4. Information in Sect. 4 is presented in tabular form insofar as it is practical, with a minimum of text, for ease of reference and in an effort to facilitate the reader's assessment of the concept and its elements. Section 5 summarizes and emphasizes aspects of particular significance to environmental issues. Section 6 reviews the major points of the report, identifies remaining uncertainties that require further investigation, and presents recommendations for future efforts.

Parts of the model have major implications for environmental issues on the ORR. Over large parts of the ORR, and especially those where most wastes have been disposed, the marked decrease in permeability with depth imposes severe limitations on water flux through the subsurface. On the average, $\sim 56 \mathrm{~cm} /$ year of precipitation infiltrates the ORR surface. Because of the vertical contrast in permeability, as much as $95 \%$ of this water is quickly discharged through a zone at and near the surface via short, transiently saturated flow paths to adjacent surface drainageways. Less than $4 \mathrm{~cm} /$ year reaches the groundwater zone in valleys underlain by aquitards (mainly Bear Creek Valley, the head of East Fork 
Poplar Creek valley, Bethel Valley, and Melton Valley). Flow in the groundwater zone is also vertically inhibited by decreasing permeability, so that the shallowest flow interval of the groundwater zone carries the bulk of the flow in the saturated zone to discharge to local surface waterways. A second important model element is transport processes. While water moves rapidly through fractures, the diffusion, sorption, and exchange of solutes into the adjacent earth materials result in extensive retardation and storage of waterborne contaminants as they are transported away from the contaminant source.

As indicated above, the hydrologic framework is not completely developed and definitive; undoubtedly, some aspects will remain less well developed than would be desired. For instance, confidence decreases with depth below the surface partly, but not entirely, because the availability of data decreases with depth. On the other hand, the model in its present state of development represents an important advance because it accounts for most of the phenomena observed and provides a basically complete and reliable description of the distribution of water, water flux, and related contaminant transport. Regulatory agencies increasingly emphasize the urgency of accelerating effective corrective actions. The model described here is suitable to use for those purposes now, because the basic premises are not likely to change.

Although the hydrologic framework described in this report is believed to adequately represent hydrologic properties and processes throughout the ORR (with the identified exceptions), the supporting data are necessarily generalized, thus are applicable only in a general sense to a specific site. Data acquisition for detailed characterization of a specific site is, of course, required. The general concepts in this report are useful in the planning stages of site investigation. An important connotation of the model, for example, is the close relationship between subsurface and surface flows. The most authentic and unambiguous information about contaminant movement and discharge from a waste site is available from nearby surface water records, where the local irregularities of the subsurface material properties and contaminant transport phenomena within the basin are integrated.

\subsection{IMPLICATIONS OF SCALE}

Meaningful description of groundwater flow must be made at scales larger than those tested by individual boreholes on the ORR. The standard methods for hydrogeologic data acquisition, analysis, interpretation, and modeling were developed for the characterization of reasonably homogeneous aquifers, including some uniformly fractured rocks. In such 
settings, hydrogeologic properties are spatially correlated, and interpolations can be made to predict aquifer properties where there are few or no data. In the Oak Ridge area, however, the rocks exhibit abrupt, localized discontinuities in fracture porosity, fracture permeability, and aqueous concentrations of chemical constituents. Under these conditions, spatial interpolation is difficult; the utility of a measurement is determined by the applicable distance, area, or volume of subsurface materials measured.

Rocks in the ORR have little intergranular porosity and permeability, but fractures are present throughout. As indicated by the cubic law, doubling a fracture aperture increases hydraulic conductivity by a factor of 4 and increases groundwater flow rate by a factor of 8 (see Sect. 3). Because of this relationship, a measurement of permeability in any volume of rock is almost entirely determined by the few fractures or cavities having the largest apertures. Also, a few fractures or cavities dominate the groundwater flow system in any area. Virtually all groundwater flow occurs through networks of connected fractures or cavities formed along fractures, but variations in the number and aperture of openings within these networks occur along the flow paths. These differences determine flow direction (lateral and vertical) and whether flow path splits or joins occur at fracture intersections. Values for transmissivity and hydraulic conductivity span $\sim 7$ to 8 orders of magnitude, and values of storativity span $\sim 3$ orders of magnitude.

The movement of a water molecule is indeterminate through a fracture network of the ORR, and a characterization of the water-bearing materials requires determinations of average hydraulic properties within some representative volume. In granular porous media (sand and gravel aquifers) the averaging of measurement values for volumes of $<1 \mathrm{~m}^{3}$ typically results in an adequate description of groundwater flow. Average hydraulic properties determined over such volumes approximate uniformity over a region of interest. In contrast, hydraulic properties averaged over small volumes on the ORR, as in the case of a borehole and its immediate environment, are extremely variable.

Although hydraulic properties are widely variable at the borehole scale, an important hypothesis in this report is that hydraulic properties of the aquitards averaged over volumes of 1 to perhaps $100 \mathrm{~m}^{3}$ may vary $<1$ order of magnitude. Thus, while characterization of groundwater movement at the borehole scale is intractable on the ORR, a meaningful description is possible at slightly larger scales. For the Knox aquifer, the scale at which spatial variations in properties are adequately integrated is not known but may be on the order of thousands of cubic meters. 
Another important premise in this report is that nearly all groundwater passing through waste disposal areas eventually discharges into streams on the ORR. Because the primary pathway for off-site release of contamination is by surface water, the catchment-wide scale is most relevant for characterizing contaminant flux. Thus, the intractability of characterizing groundwater flow and contaminant transport at the borehole scale does not compromise characterization objectives. Furthermore, characterization activities, such as detailed seep, spring, and stream monitoring that effectively integrate over larger volumes, will yield more useful results than small-scale (i.e., borehole) monitoring.

\section{5 HYDROLOGIC AND GEOLOGIC SETTING}

\subsubsection{General Hydrology}

Mean annual precipitation in the period 1954-83 was $133 \mathrm{~cm}$ for stations near Oak Ridge National Laboratory (ORNL); the minimum and maximum amounts in the same period were 90 and $190 \mathrm{~cm}$ of water (Webster and Bradley 1987). The wettest period is January through March and the driest is August through October. During those periods, mean monthly precipitation at Oak Ridge is $13-16 \mathrm{~cm}$ and $7-10 \mathrm{~cm}$ of water, respectively. Droughts lasting $7 \mathrm{~d}$ occur $\sim 17 \%$ of the time, but droughts lasting $15 \mathrm{~d}$ occur, on the average, only $1.8 \%$ of the time (McMaster 1967, Fig. 5). An average $76 \mathrm{~cm}$ of water $(57 \%)$ is consumed by evapotranspiration, and $57 \mathrm{~cm}$ of water (43\%) leaves the area as streamflow (Tennessee Division of Water Resources 1961).

\subsubsection{Physiography}

The ORR is located on the westem side of the Valley and Ridge physiographic province, $\sim 32 \mathrm{~km}$ west of Knoxville, Tennessee. The general features that distinguish this province are (1) parallel ridges and valleys typically oriented from northeast to southwest, (2) topography influenced by alternating weak and strong strata exposed to erosion through a relatively great amount of folding and faulting, (3) a few major transverse streams with subsequent streams forming a trellislike drainage pattern, (4) many ridges with accordant summit levels suggesting former erosion surfaces (peneplanation), and (5) many water and wind gaps through resistant ridges. The scarp (northwest-facing) slopes of these ridges are relatively shon, steep, and smooth. The dip (southeast-facing) slopes are longer, shallower, and hummocky to dissected. 
Elevations range from $225-410 \mathrm{~m}$ above sea level. Surface slopes average $\sim 0.075$ and generally have a range of $0.03-0.3$. However, the steepest part of a scarp slope may be $>0.5$, whereas slopes on the floodplain of the Clinch River are $\sim 0.015$. Drainage patterns have a dendritic shape in headwater areas and a trellis shape farther downstream.

\subsubsection{Geology}

The Geologic Studies Task of ORRHAGS is preparing a modern de tailed geologic map of the ORR subdividing all rock units and displaying mesoscopic structural data. A goal is to establish correlations between fracture systems and associated subsurface fluid flow, and formulation of a structural-hydrologic model that enables interpretation of the behavior of groundwater and other subsurface fluids on the ORR. Understanding of the structural setting and its controls on fluid flow at depth is an element in developing a model for groundwater movement in tils area. Progress toward completion of this subtask is described in Hatcher et al. (1992).

\subsubsection{Stratigraphy}

Rock units of the stratigraphic section in the ORR range in age from Early Cambrian to Silurian (Table 1.1). The stratigraphic units comprise a complex assemblage of lithologies, with representatives from the entire Cambrian and Ordovician section. The total thickness of section in the ORR is $\sim 2.5 \mathrm{~km}$. In general, the Cambro-Ordovician Knox Group and part of the overlying Chickamauga Group form the competent units within the major thrust sheets in this area. Each major stratigraphic unit (and formations within those units), becausc of compositional and textural properties, possesses unique mechanical characteristics that respond differently to the strain fields affecting these rocks through time. Therefore, each may have experienced a slightly different scheme of brittle deformation that subsequently may affect the transmission of fluids through them.

The Rome Formation, 9()- to 125-m thick, of Late Lower Cambrian and Early Middle Cambrian age, is the oldest formation exposed in the ORR, where it underlies Haw Ridge and Pine Ridge, both of which cross the entire length of the reservation, and a shorter, unnamed ridge between Pine Ridge and East Fork Ridge. A belt of deeply weathered shale and calcareous beds of variegated coloration similar to that of the shale and siltstone of the Rome Formation underlies the valley northwest of Pine Ridge. 
Table 1.1. Geologic units of the Oak Ridge Reservation. Names in italic are units that make up the Knox aquifer. Other units forn the ORR aquitards.

\begin{tabular}{|c|c|c|c|}
\hline Unit & Age & $\begin{array}{l}\text { Thick- } \\
\text { ness, } m\end{array}$ & Lithology \\
\hline Rockwood Formation & Silurian & 120 & Sandstone, shale \\
\hline Sequatchic Formation & U. Ordovician & 60 & Argillaceous limestone \\
\hline Reedsville Shale & U. Ordovician & 60 & Calcareous shale \\
\hline Chickamauge Group & M. Ordovician & $\begin{array}{l}400- \\
700\end{array}$ & $\begin{array}{l}\text { Limestone, argillaceous } \\
\text { limestone, shale, siltstone }\end{array}$ \\
\hline $\begin{array}{l}\text { Knox Group } \\
\text { Mascot } \\
\text { Dolomite } \\
\text { Kingsport } \\
\text { Formation } \\
\text { Longview } \\
\text { Dolomile } \\
\text { Chepultepec } \\
\text { Dolomite } \\
\text { Copper Ridge } \\
\text { Dolomite }\end{array}$ & $\begin{array}{c}\text { Lower } \\
\text { Ordovician, } \\
\text { Upper Cambrian }\end{array}$ & $\begin{array}{c}75-120 \\
90-150 \\
40-60 \\
150-215 \\
245-335\end{array}$ & $\begin{array}{l}\text { Massive dolomite, siliceous } \\
\text { dolomite, bedded chert, } \\
\text { limestone, some clastics }\end{array}$ \\
\hline $\begin{array}{l}\text { Conasauga Group } \\
\text { Maynardville } \\
\text { Limestone } \\
\text { Nolichucky Shale } \\
\text { Dismal Gap Fimtn } \\
\text { (formerly Mary- } \\
\text { ville Limestone) } \\
\text { Rogersville Shale } \\
\text { Rutlodge } \\
\text { Limestone } \\
\text { Pumpkin Valley } \\
\text { Shale }\end{array}$ & $\begin{array}{l}\text { Middle, Upper } \\
\text { Cambrian }\end{array}$ & $\begin{array}{l}125-145 \\
100-150 \\
95-120 \\
20-35 \\
30-40 \\
90-100\end{array}$ & $\begin{array}{l}\text { Dolomitic limestone, } \\
\text { limestone } \\
\text { Shale, siltstone, calcar- } \\
\text { cous siltstone and shale, } \\
\text { shaly limestone, limestone }\end{array}$ \\
\hline Rome Formation & Lower Cambrian & $90-125$ & $\begin{array}{l}\text { Shale, silistonc, sandstone, } \\
\text { local dolomite lenses }\end{array}$ \\
\hline
\end{tabular}

The roughly 520-m-thick Conasauga Group underlies Meiton Valley and Bear Creek Valley as well as smaller areas in the . icinity of K-25 and northwest of Pine Ridge. The group traditionally is subdivided in central East Tennessee into the Middle Cambrian Pumpkin Valley Shale, Rutledge Limestone, Rogersville Shale, and Maryville Limestone (the Dismal Gap Formation in Hatcher et al. 1992), and the Upper Cambrian Nolichucky Shale and Maynardville Limestone. With the exception of the Maynardville Limestone, the Conasauga is a monotonous sequence of shale, siltstone, and thin-bedded limestone. The Maynardville, $\sim 100 \mathrm{~m}$ thick, is in general massively bedded limestone and dolomite. Because of the many years of extensive waste disposal activities in Melton and Bear Creek valleys, the Conasauga Group is the most thoroughly studied rock unit in the ORR. 
The Knox Group is an Upper Cambrian-Lower Ordovician dolomite and limestone sequence divisible into five formations: the Cambrian Copper Ridge Dolomite, Ordovician Chepultepec Dolomite, Longview Dolomite, Kingsport Formation, and Mascot Dolomite. It underlies Copper Ridge, Chestnut Ridge, Blackoak Ridge, and McKinney Ridge at the $\mathrm{K}-25$ Site. Total thickness of the unit ranges between 600 and $900 \mathrm{~m}$, with the Copper Ridge Dolomite making up roughly one-third of the total. It forms the principal strong unit to support the folding and low-angle thrust faulting that occurs throughout the Valley and Ridge.

The Chickamauga Group represents deposition on a regionally extensive disconformity on the top of the Knox Group. Relief on this surface accounts for variable stratigraphic thicknesses in the lower Chickamauga unit. In Bethel Valley, where the section is incomplete, the Chickamauga Group consists of more than $400 \mathrm{~m}$ of variably thick maroon shale-dominated units separated by gray limestones. In East Fork Valley, the more than $700 \mathrm{~m}$ thick section is complete; the lower $625 \mathrm{~m}$ or so is dominantly gray limestone, shaly limestone, and minor shale beds. The upper $75 \mathrm{~m}$ or so is shale.

The Lower Silurian Rockwood Formation and the Upper Devonian-Lower Mi 3sissippian Chattanooga Shale are associated with the synclinal structure along the Whiteoak Mountain Thrust Fault, and occupy only a small surface area within the ORR.

\subsubsection{Structure}

The ORR is in the Tennessee portion of the Appalachian Valley and Ridge fold and thrust belt, characterized by the presence of a number of southeast-dipping overlapping thrust sheets. Two major thrusts, the Copper Creek and Whiteoak Mountain faults, are exposed in the ORR, attended by a variety of geologic structures on several scales. Although the two major thrust faults in the area are generally single surfaces, locally small overlapping faults have developed along them. Small- and intermediate-scale folds and tear faults $(10-100 \mathrm{~m})$ may locally influence the hydrologic system.

The ORR contains a variety of geologic structures on several scales. The map-scale structure is dominated by southeast-dipping beds interrupted by two major thrust faults and the locally overtumed East Fork Ridge and Pilot Knob synclines (McMaster 1962).

Overall, the faults and stratigraphy strike northeast and dip to the southeast, except in the synclines where dips swing to the northwest. Outcrop-scale structures include minor 
folds, faults, and tractures. The formation of most of these structures is closely related to map-scale structures. Most minor folds and faults observed occur in either the Rome Formation or Conasauga Group, a function of lithology, stratigraphy, and proximity to map-scale faults and folds.

The most pervasive structural feature is extensional, hybrid, and shear fractures, which are an important factor in groundwater flow in this region. An understanding of joint orientation, mechanics of formation, and timing of development is needed. Although nonsystematic fractures are always present, fractures tend to develop systematic orientations over a particular area, which allow general patterns to be interpreted.

Fractures are present throughout all rocks on the ORR, and a large majority constitute a single cubic system (three orthogonal sets) of extension fractures (Dreier et al. 1987; Sledz and Huff 1981). One fracture set is formed by bedding planes, which have an average strike of $\sim \mathrm{N} 55^{\circ} \mathrm{E}$; the dip is variable but commonly is $\sim 30-40^{\circ} \mathrm{SE}$ (Stockdale 1951). Two other joint sets are approximately strike parallel and dip parallel; at shallow depths, these sets are commonly angled $\sim 50-60^{\circ}$ below the horizon. These three fracture sets may occur in any locality, and other exiension and shear fractures may also be present. Fractures are abundant on rock outcrops, in saprolite, and at shallow depths in fresh bedrock. Dreier et al. (1987) measured an average fracture density of $\sim 200 / \mathrm{m}$ in saprolite of the Maryville Limestone and Nolichucky Shale at Waste Area Grouping (WAG) 6 near ORNL. At the other extreme, Sledz and Huff (1981) measured a minimum fracture density of $5 / \mathrm{m}$ in fresh rock. Fewer open fractures occur at deeper levels. As described by Haase et al. (1985), fracture frequency is variable, but most fractures observed in cores occur within limestone or sandstone layers $>0.5 \mathrm{~m}$ thick, and many fractures are filled or partly filled with secondary minerals.

Most fractures are short, a few centimeters to $\sim 1 \mathrm{~m}$ in length (longest dimension). Sledz and Huff (1981) found a relatively uniform fracture length of $\sim 12 \mathrm{~cm}$ in shale but a fracture length that increases with bed thickness in siltstone. Haase et al. (1985) observed numerous fractures $\sim 0.1-1.5 \mathrm{~m}$ long within limestone and sandstone units of the Conasauga Group and the Rome Formation. Groundwater flows occur only through networks of pervious, connected fractures. Long fractures are more likely to be widely spaced than are short fractures, but long fractures are also more likely to have a relatively large aperture (gap width) and to be connected. In limestone, typical fracture spacings range from $<5 \mathrm{~cm}$ for very thin beds to $>3 \mathrm{~m}$ for very thick to massive beds. The areal 
extent of fractures may be only a few square meters for thin to very thin beds, but pervious bedding-plane fractures may be $10^{3}$ to $10^{6} \mathrm{~m}^{2}$ for medium to massive beds (Ford and Williams 1989). Also, many pervious fractures cross one to several rock layers but terminate at the connections with other fractures (Ford and Williams 1989).

In the Knox Group, and to a much more limited extent in other carbonate rocks of the ORR, sorne fractures are enlarged by solution. As solution progressed in the upgradient direction of the water table, some conduits, as they intercepted smaller cavities, became dominant flow channels, in a way somewhat analogous to the development of a surface drainage system. It is only in the Knox Group and the adjacent Maynardville Limestone (together in this report called the Knox aquifer) that cavity systems are highly developed and areally extensive. 


\section{OVERVIEW OF THE CONCEPTUAL MODEL}

In this section a conceptual model of subsurface flow and contaminant transport on the ORR is introduced and summarized. This model represents an integration of data, information, and concepts from many technical studies and is intended to describe, generically for the ORR, water flux and water chemistry as they vary in three dimensions and in time. The model is consistent with most but not all obscrvations and measurements. Some parts of the model are limited by data availability. Because uncertainty exists in some parts, the model described here is a framework upon which to build as new data are obtained. The purpose of this report is not only to convey current understanding but also to establish a baseline to aid in the interpretation of future studies and to highlight areas of uncertainty. Evidence supponing this conceptual model, along with descriptions of remaining uncertanties, is discussed in Sect. 4, and implications for contaminart transport are in Sect. 5.

Two broad hydrologic units are identified in the ORR, each having fundamentally different hydrologic characteristics. The Knox Group and the Maynardville Limestone of the Conasauga Group constitute the Knox aquifer, in which flow is dominated by solution conduits. The remaining geologic units (see Sect. 1.5) constitute the ORR aquitards, in which flow is dominated by fracules. The generalized map below shows surface distribution of the Knox aquifer and the ORR aquitards.

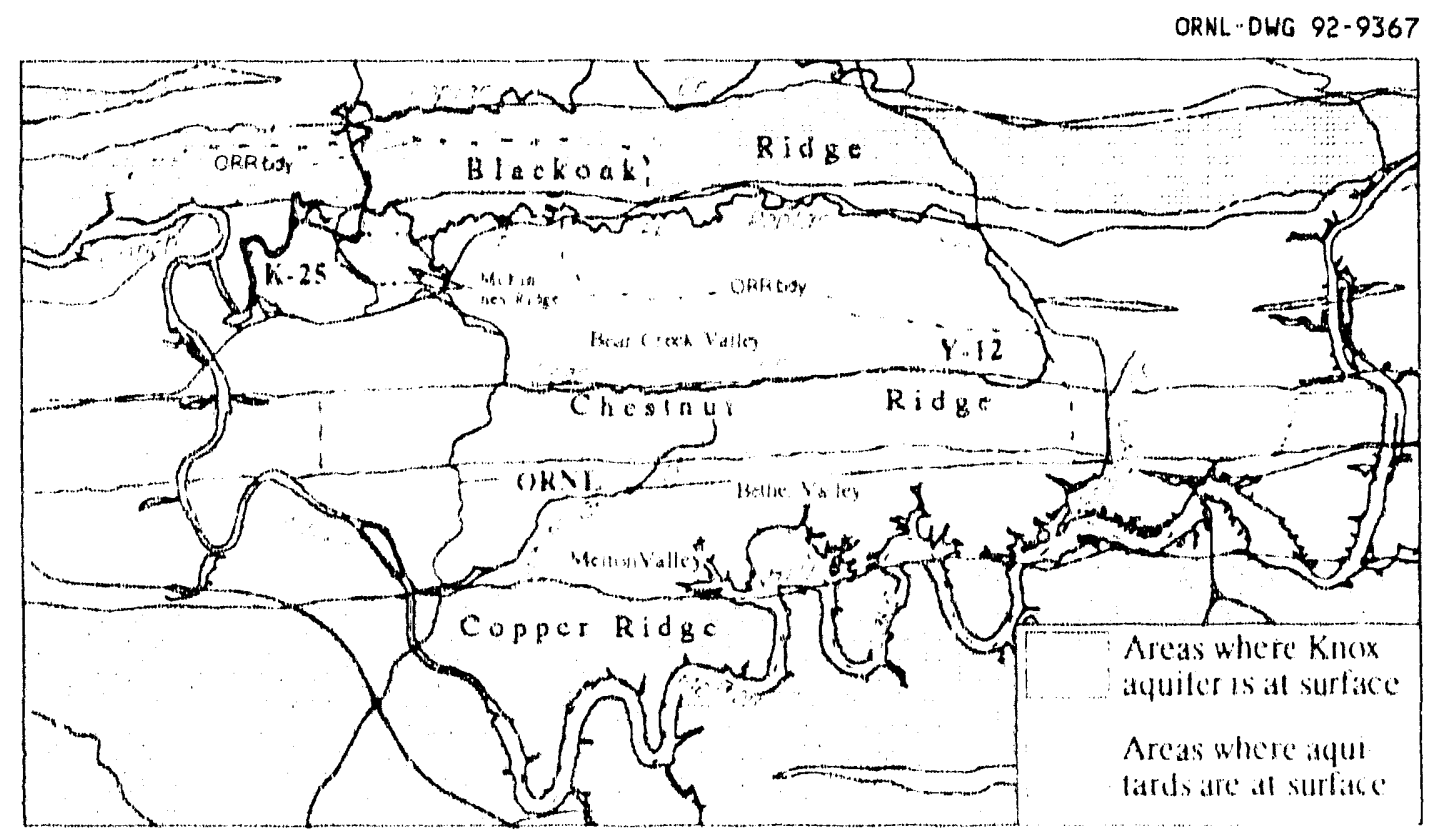


The subsurface flow system in both the Knox aquifer and in the ORR aquitards can be divided as follows (Fig. 2.1): the stormflow zone; the vadose zone; the gro'undwater zone, which is subdivided into the water table interval, the intermediate interval, and the deep interval; and the aquiclude. These hydrologic subsystems are defined on the basis of water flux, which decreases with depth; the largest flux is associated with the stormflow zone and the smallest with the aquiclude. Note that these subsystems are vertically gradational and are not separated by discrete boundaries. Because a subsystem does not operate independently of the system as a whole, it is not possible to understand a given subsystem out of context of its interactions with the entire system. Although it is useful to simplify a system by subdividing it for the purpose of analysis, it is important to understand that major processes within a subsystem, as well as the interactions that occur between subsystems, are functions of the system as a whole.

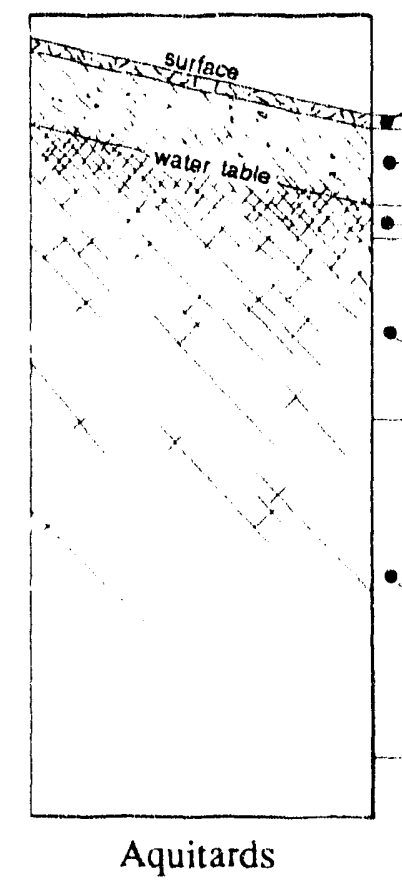

Not to scalis

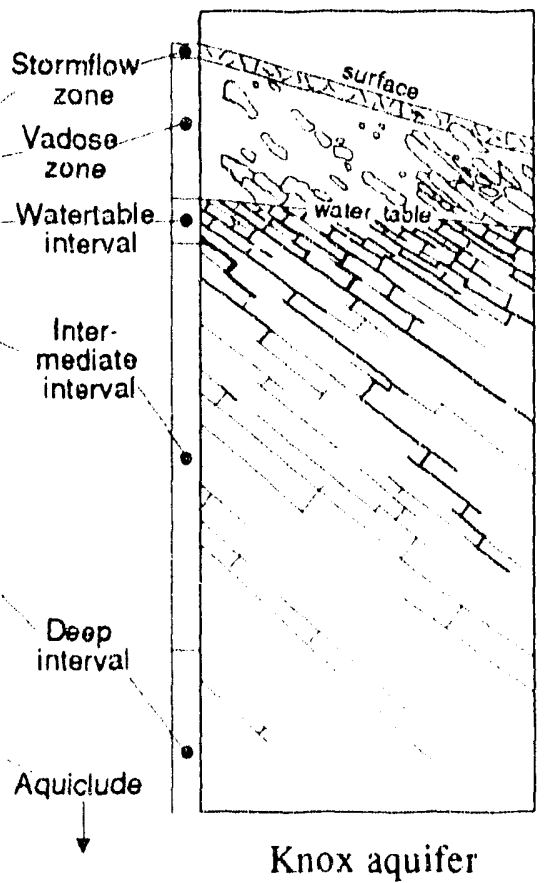

Knox aquifer
ORNL-DWG $92-9368$

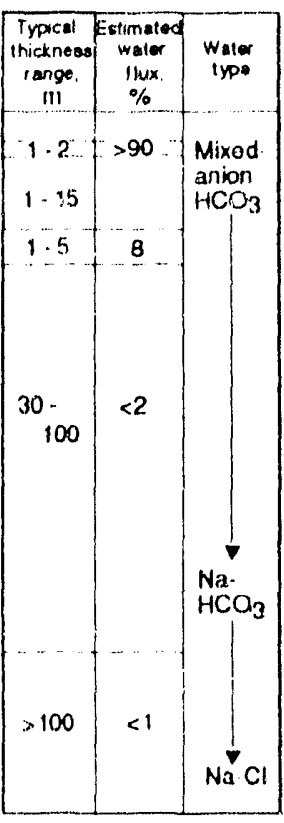

Fig. 2.1. Schematic vertical relationships of flow zones of the ORR, estimated thicknesses, water flux, and water types.

The hydrologic subsystems description differs from the stratigraphic units described in Hatcher et al. (1992) in that hydrologic boundaries do not coincide with stratigraphic boundaries in many cases. Hydrologic subsystems are defined in the vertical, superimprsed on stratigraphic units. In other words, the hydrologic subsystems are continuous across the entire reservation, but the subsystem properties and boundaries are 
locally influenced by hydrostratigraphic units. Although many factors influence groundwater flow on the ORR, topography, surface cover, geologic structure, and lithology exhibit strong influence on the hydrogeology. Variations in these features result in water flux variations.

Because of substantial topographic relief and a marked vertical decrease in permeability, subsurface flow is predominantly shallow on the ORR. In addition to groundwater flow, contaminant migration rates are strongly influenced by geochemical processes, including ion exchange, sorption, and precipitation/dissolution of mineral phases. The retardation of contarninants on the ORR resulting from geochemical processes is specific to each contaminant. The rate of tritium migration, for example, is virtually bie same as groundwater, whereas the migracion of cesium through the ORR aquitards may be too small to detect. Although chemical processes constitute the dominant retardation mechanism for many contaminants, the process of matrix diffusion is emphasized in this report because it is generic to all contaminants and provides the basis for a "worst case" scenario for contaminant migration.

\subsection{STORMFLOW ZONE}

Detailed water budgets indicate that $\sim 90 \%$ of active subsurface flow occurs through the 1- to 2-m-deep stormflow zone. Natural areas of the ORR are heavily vegetated, and the stormflow zone approximately corresponds to the root zone. Infiltration tests indicate that this zone is as much as 1000 times more permeable than the underlying vadose zone. During rain events, the stormflow zone partially or completely saturates and then transmits water laterally to the surface-water system. When the stormflow zone becomes completely saturated, overland flow occurs.

Where such excavations as wast trenches penetrate the stormflow zone, a commonly otserved condition known as bathtubbing can occur in which the excavation fills with water. Between rain events, as the stormflow zone drains, flow rates decrease dramatically and flow becomes nearly vertical toward the underlying vadose zone. The transmissive capability of the stormflow zone is created primarily by root channels, worm holes, clay aggregation, fractures, etc., collectively referred to as large pores. Although highly transmissive, large pores comprise only $-0.2 \%$ of the total void volume of the stormflow zone. Because most of the water mass resides within less transmissive small pores, 
advective-diffusive exchange between large and smail pores substantially reduces contaminant migration rates relative to fluid velocities in large pores.

\subsection{VADOSE. ZONE}

A vadose zone exists throughout the ORR except where the water table is at land surface, such as along perennial stream channels. The thickness of the vadose zone is greatest beneath ridges, and thins towards valley floors. Beneath ridges underlain by the Knox aquifer (Copper Ridge, Chestnut Ridge, McKinney Ridge, and Blackoak Ridge), the vadose zone commonly' is as much as $50 \mathrm{~m}$ thick, whereas beneath ridges underlain by the Rome Formation (Haw Ridge and Pine Ridge) the vadose zone is typically $<20 \mathrm{~m}$ thick. In lowland areas near streams, a permanent vadose zone does not exist because the stormflow zone intersects the water table. The vadose zone consists of regolith composed mostly of clay and silt, most of which is derived from the weathering of bedrock materials, and which has significant water storage capacity. Most recharge through the vadose zone is episodic and occurs along discrete permeable features that may become saturated during rain events, even though surrounding micropores remain unsaturated and contain trapped air. During recharge events, flow paths in the vadose zone are complex, controlled by the orientation of structures of the materials, such as relict fractures. Between recharge events, flow rates decrease dramatically, and flow paths are toward the groundwater zone.

\subsection{GROUNDWATER ZONE}

A convergence of evidence indicates that most water in the groundwater zone of the aquitards is transm:tted through a layer, $\sim 1-5 \mathrm{~m}$ thick, of closely spaced, connected fractures near the water table, as shown below.

ORNL-DWG $92-9369$

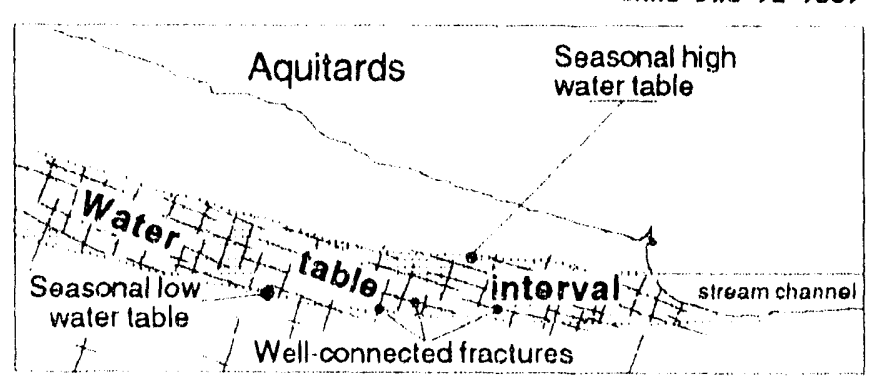

Many open fractures, which extend only a short distance into the rock, can be seen on outcrops, and the near correspondence of the water table with the top of weathered bedrock 
in the ORR is probably not coincidental. Regolith above this level has been formed by a large water flux, and the presence of unweathered bedrock at deeper levels apparently indicates a smaller water flux. Cyclic variations in water table elevation change the saturated thickness of the permeable layer. The resulting changes in transmissivity explain an order-of-magnitude fluctuation in groundwater discharge rates even though (1) contours of annual high and low water table elevations show little change in hydraulic gradient and (2) seasonal changes of water level in most wells are small compared with height of the water level above stream level. Opposite changes in hydraulic gradient and saturated thickness occur from one topographic location to another. The product of transmissivity and hydraulic gradient is constant (or increases with recharge) along each flow path.

The range of seasonal fluctuations in depth to the water table and in rates of groundwater flow vary significantly across the reservation. In the areas of the Knox aquifer, seasonal fluctuations in water levels average $5 \mathrm{~m}$ and the specific discharge through the active groundwater zone is typically $9 \mathrm{~m} /$ year. In the aquitards of Bear Creek Valley, Melton Valley, East Fork Valley, and Bethel Valley, seasonal fluctuations in water levels average $1.5 \mathrm{~m}$, and typical specific discharge is $5 \mathrm{~m} /$ year.

As in the stormflow zone, the bulk of water mass in the water table interval resides within porous matrix blocks between fractures, and diffusive exchange between matrix and fractures reduces contaminant migration rates relative to fracture fluid velocities. For example, the leading edge of a geochemically nonreactive contaminant plume migrates along fractures at a typical rate of $1 \mathrm{~m} / \mathrm{d}$; however, the center of mass of a contaminant plume typically migrates at only $0.05 \mathrm{~m} / \mathrm{d}$.

Below the water table interval, fracture control becomes dominant in flow path direction. The base of the water table interval corresponds to the zone of transition from regolith to bedrock. In the intermediate interval of the groundwater zone, groundwater movement occurs primarily in permeable fractures that are poorly connected in three dimensions. In the Knox aquifer a few hydrologically dominant cavity systems control groundwater movement in this zone, but in the aquitards the bulk of flow is through fractures, along which permeability may be increased by weathering. 
Fracture orientations measured in outcrop fall into three sets, as illustrated below.

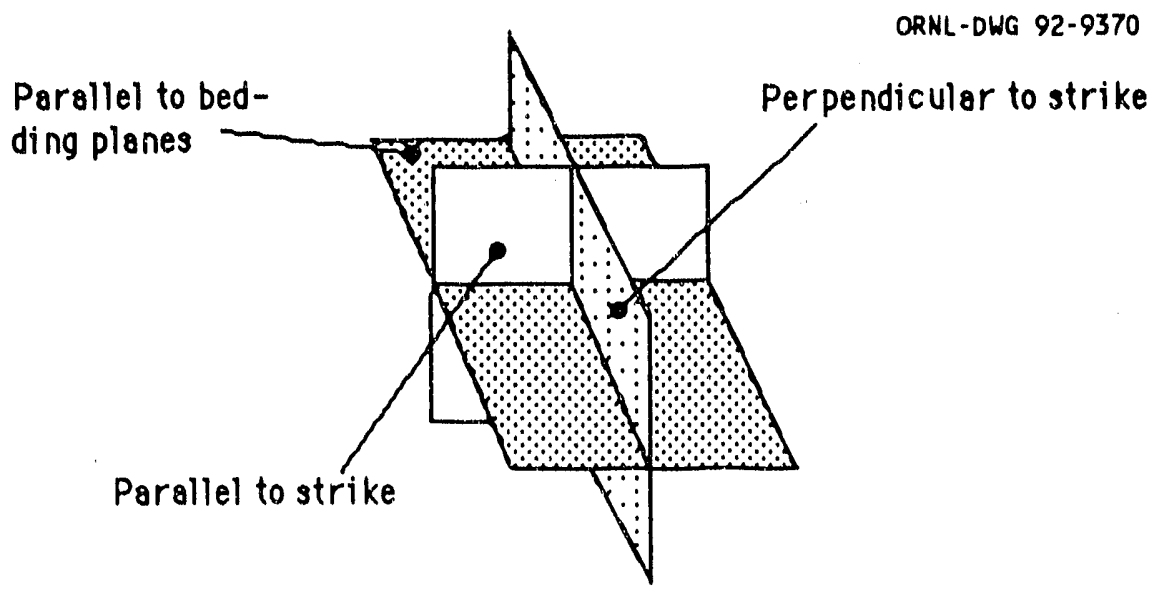

One fracture set is parallel to and along bedding planes and thus parallel to strike. The dip of this fracture set varies with bedding plane dip, generally ranging between 10 and $50^{\circ}$. A second set is also parallel to strike but perpendicular to bedding planes. The dip of this set also varies with bedding plane dip and thus is a function of depth, inclined near the surface where bedding planes dip more steeply, then vertical at depth where bedding plane dip flattens. A third set is perpendicular to strike.

Fracture orientations and converging groundwater flow paths in and near valley floors give rise to preferential groundwater movement along strike, toward cross-cutting tributary drainageways. Bedding-plane and strike-parallel fractures and their intersections are more permeable than the dip-parallel fractures, and flow paths are along-valley toward crosscutting tributary streams.

The chemical characteristics of groundwater change from a mixed-cation- $\mathrm{HCO}_{3}$ water type to an $\mathrm{Na}-\mathrm{HCO}_{3}$ type in the ORR aquitards at depths ranging from 30 to $50 \mathrm{~m}$. Although the geochemical mechanism responsible for this change in water types is not entirely quantified, it probably is related to water residence time. The transition from $\mathrm{Ca}-\mathrm{HCO}_{3}$ to $\mathrm{Na}-\mathrm{HCO}_{3}$ serves as a useful marker and is used in this report to distinguish the intermediate groundwater interval from the deep interval, a transition which is not marked by a distinct change in rock properties.

Below the intermediate interval, small quantities of water are transmitted through discrete fractures in the deep interval. The hydrologically active fractures in the deep interval are 
significantly fewer in number and shorter in length than in the other intervals, and the spacing is greater, partly because of less dissolution of fracture fillings. Fracture orientations are similar to those described earlier for the water table interval.

Wells finished in the deep interval of the ORR aquitards typically yield $<0.1 \mathrm{~L} / \mathrm{min}$ and thus have no potential for water supply. The specific storage of the bedrock aquitard is small, and as a result some hydraulic heads in the deep interval respond to precipitation events, even though the associated water flux is small. The chemical characteristics of groundwater in the deep interval are different from those of the water table interval and probably reflect longer water residence times. Although diffusive transfer between fractures and metrix blocks is an important process in the deep interval, the total matrix porosity is less than that of the water table interval, the vadose zone, or the stormflow zone, thereby reducing the retarding effect on contaminant migration rates relative to more shallow zones.

\subsection{AQUICLUDE}

Saline water, having total dissolved solids ranging irom 2,000 to $275,000 \mathrm{mg} / \mathrm{L}$, lies beneath the deep interval of the groundwater zone, delineating an aquiclude. Chemically, this water resembles brines associated with major sedimentary basins, but its origin and rate of movement are not known. The depth to the aquiclude is $\sim 180-240 \mathrm{~m}$ in Melton and Bethel valleys and is believed to be $>300 \mathrm{~m}$ in portions of Bear Creek Valley. Depth to the aquiclude in areas of the Knox aljuifer is not known but is believed to be $>350 \mathrm{~m}$. 


\section{SYSTEM PROPERTIES}

Subsurface flow and contaminant transport on the ORR are influenced by properties and processes that are distinctive to fractured-rock, topographically controlled hydrogeology. For example, the low hydraulic conductivity $\left(10^{-4}\right.$ to $\left.10^{-8} \mathrm{~cm} / \mathrm{s}\right)$ of much of the ORR subsurface materials creates difficulties in measuring hydraulic parameters and sampling for water quality (Dreier and Toran 1989; Moore 1988). Water levels in some deeper wells on the ORR may require more than 5 years to recover from drawdown caused by drilling. All rocks of the ORR are fractured. The permeable features formed along some fractures produce complexity both in monitoring and in predicting fluid flow and solute transport. Permeable features create zones of fast flow in which solutes may move in directions that deviate from the direction of maximum hydraulic gradient.

Figure 3.1 illustrates the definitions of several parameters that are important in the context of flow and transport in fractured porous media. Most of the fluid flow occurs through

ORNL-DWG $92-9.371$

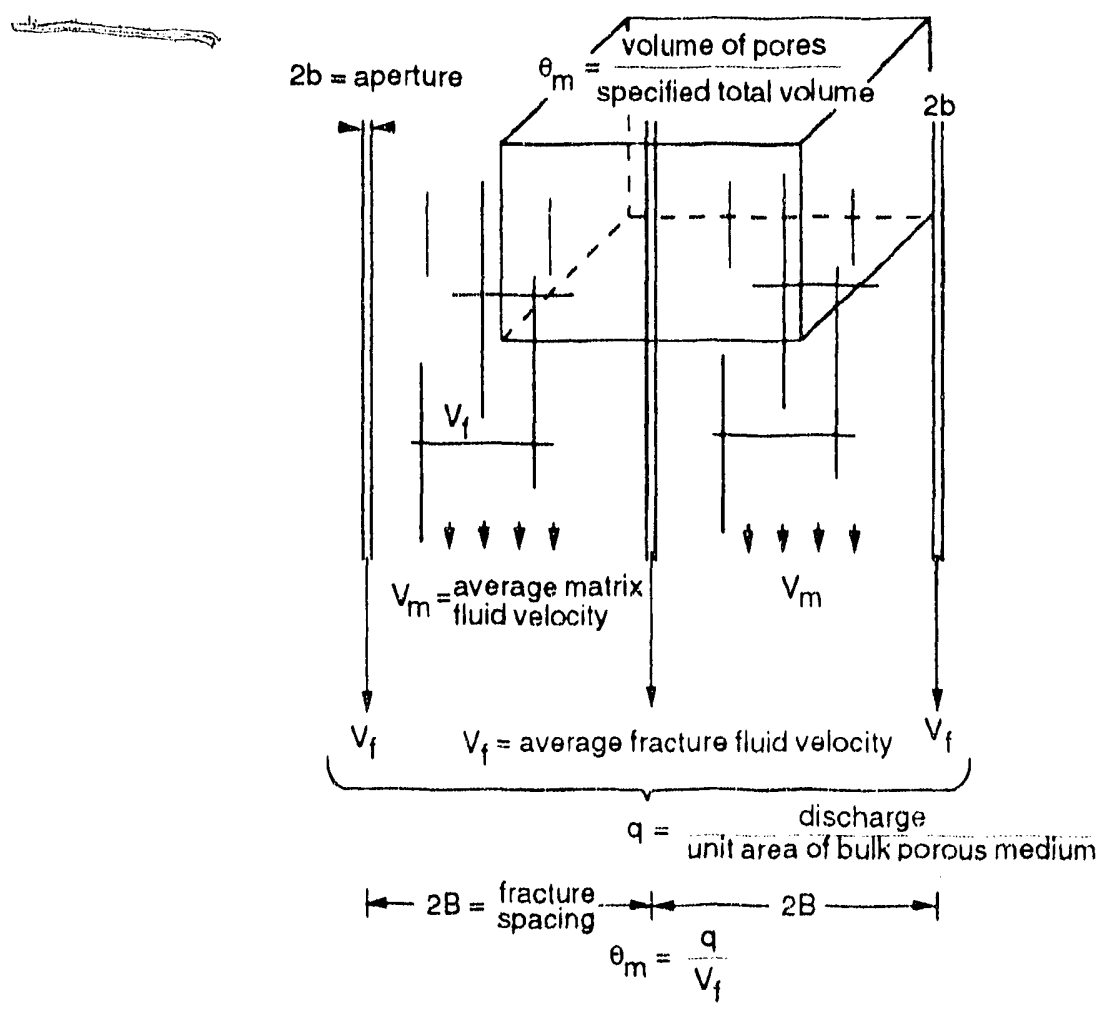

Fig. 3.1. Definitions of several parameters important in the context of flow and transport in fractured porous media. 
discrete permeable features (typically fractures); however, most of the fluid mass resides within the porous matrix of the rock materials between permeable features.

Hydrograph analysis, pumping tests, and tracer tests on shallow wells indicate that the effective porosity for the groundwater zone is in the range of $10^{-3}$ to $10^{-5}$. Such low values give rise to large fluid velocities within permeable features, even though the specific discharge is low. For example, a typical specific discharge for the groundwater zone of the ORR aquitards is $5 \mathrm{~m} /$ year; however, a typical fluid velocity in a permeable fracture may be $2000 \mathrm{~m} /$ year. Although such velocities imply extremely rapid contaminant migration rates, the associated mass flux is small, and molecular diffusion transfers dissolved contaminants from fractures into the porous marrix. The net effect of this process, known as matrix diffusion, is to reduce contaminant mobility as a result of movement into immobile water within the matrix.

The rate at which contaminants transfer from the face of a fracture into the matrix depends on the concentration gradient, the diffusive cross-sectional area, and the molecular diffusion coefficient. When a contaminant is first introduced into fractured porods media, very large concentration gradients exist between fractures and the porous matrix. The rate of diffusive transfer is greatest when a contaminant is first introduced and continually declines as concentrations in matrix water increase. Molecular diffusion coefficients for most ionic species in aqueous solution are remarkably similar and range from $\sim 1 \times 10^{-5}$ to $3 \times 10^{-5}$ $\mathrm{cm}^{2} / \mathrm{s}$ (Cassler 1984). Thus the effects of matrix diffusion are generic to a large variety of contaminants. However, organic and inorganic colloids transported through the subsurface may be excluded from the matrix because of size. Such contaminants as ${ }^{137} \mathrm{Cs}$ that have sorbed onto colloids may be transported at large velocities with little diffusive attenuation into the matrix because of size exclusion; however, such transport has not been documented on the ORR.

Although such permeable features as fractures control the flow of groundwater on the ORR, only those that are hydraulically active and connected in three dimensions are significant in groundwater movement. A major difficulty in characterizing groundwater flow paths in the ORR aquitards is the identification of hydraulically active fractures. For example, extensive fracture mapping in outcrops shows that fracture spacings vary from $2 \mathrm{~cm}$ to $\sim 1.5 \mathrm{~m}$ with a geometric mean of $5.1 \mathrm{~cm}$ and a standard deviation of $30.5 \mathrm{~cm}$ $(\mathrm{n}=1100$; Lemiszki, in preparation). However, as described later in this report, an analysis of transmissivity as a function of the length of screened interval, along with an 
analysis of the vertical spacing between screens in paired monitoring wells (in which an attempt was made to finish wells in permeable intervals), suggests that hydraulically active fractures occur at spacings ranging from $7 \mathrm{~m}$ near the water table to $>35 \mathrm{~m}$ at depths $>60 \mathrm{~m}$. Unlike the occurrence of fractures in outcrop, the occurrence of hydraulically active fractures (or permeable regions) presently cannot be correlated with lithology nor are they predicted by geomechanical models of fracture genesis.

In addition to the spacing of fracture nctworks, the effective fracture aperture is an important parameter for describing groundwater flow and contaminant transport. Although some recent estimates of fracture spacings are available, virtually no direct tests of effective fracture apertures have been conducted, and such estimates are critical for modeling processes such as matrix diffusion. One way to estimate apertures from existing data is to conceptualize groundwater flow as occurring through parallel fractures. The bulk effective hydraulic conductivity of a set of parallel fractures is then given by the cubic law (Snow 1968) as

$$
K_{\text {bulk }}=\frac{2 \rho g b^{3}}{3 \mu B}
$$

where

$$
\begin{aligned}
& \rho=\text { fluid density; } \\
& g=\text { gravitational constant; } \\
& b=\text { one-half of the fracture aperture; } \\
& \mu=\text { fluid viscosity; and } \\
& B=\text { fracture spacing. }
\end{aligned}
$$

The effective porosity $\left(\theta_{\mathrm{e}}\right)$ for a planar set of fractures is given by

$$
\theta_{\mathrm{c}}=\frac{2 \mathrm{~b}}{\mathrm{~B}}
$$

The bulk $\mathrm{K}$ is an average value over fractured and unfractured regions and is less than the $K$ for a fractured region. Because estimates of $K_{\text {bulk }}$ and $\left(\theta_{\mathrm{e}}\right)$ are available, eq. (3.1) and (3.2) can be used to place bounds on the range of effective fracture apertures and spacings. For flow perpendicular to three intersecting fracture sets, eq. (3.1) is multiplied by a factor of 2 and eq. (3.2) is multiplied by a factor of 3 (Snow 1968). 
Figure 3.2 shows the relationship among $\mathrm{b}, \mathrm{B}, \mathrm{K}$ bulk, and $\theta_{\mathrm{c}}$ (assuming that apertures fall in the range of 1 to $500 \mu \mathrm{m}$ and spacings fall in the range of $0.1 \mathrm{~m}$ to $100 \mathrm{~m}$ ). Estimates of $\mathrm{K}_{\text {bulk }}$ from various hydrologic zones can be compared with estimates of $\theta_{\mathrm{c}}$ to give rough estimates of effective fracture spacings and apertures. For example, mean hydraulic conductivity in the groundwater zone is $\sim 10^{-5} \mathrm{~cm} / \mathrm{s}$ (Moore 1989). A porosity of $\sim 10^{-4}$ is estimated from the ORNL Engineering Test Facility tracer test (Davis et al. 1984). These values suggest that a fracture aperture of $50 \mu \mathrm{m}$ and a spacing of $1 \mathrm{~m}$ are reasonable at shallow depths in the groundwater zone. Lower permeabilities and porosities are expected in deeper intervals and thus smaller apertures and spacings. Although this analysis assumes uniform fracture spacings and apertures, the results are useful as a first approximation.

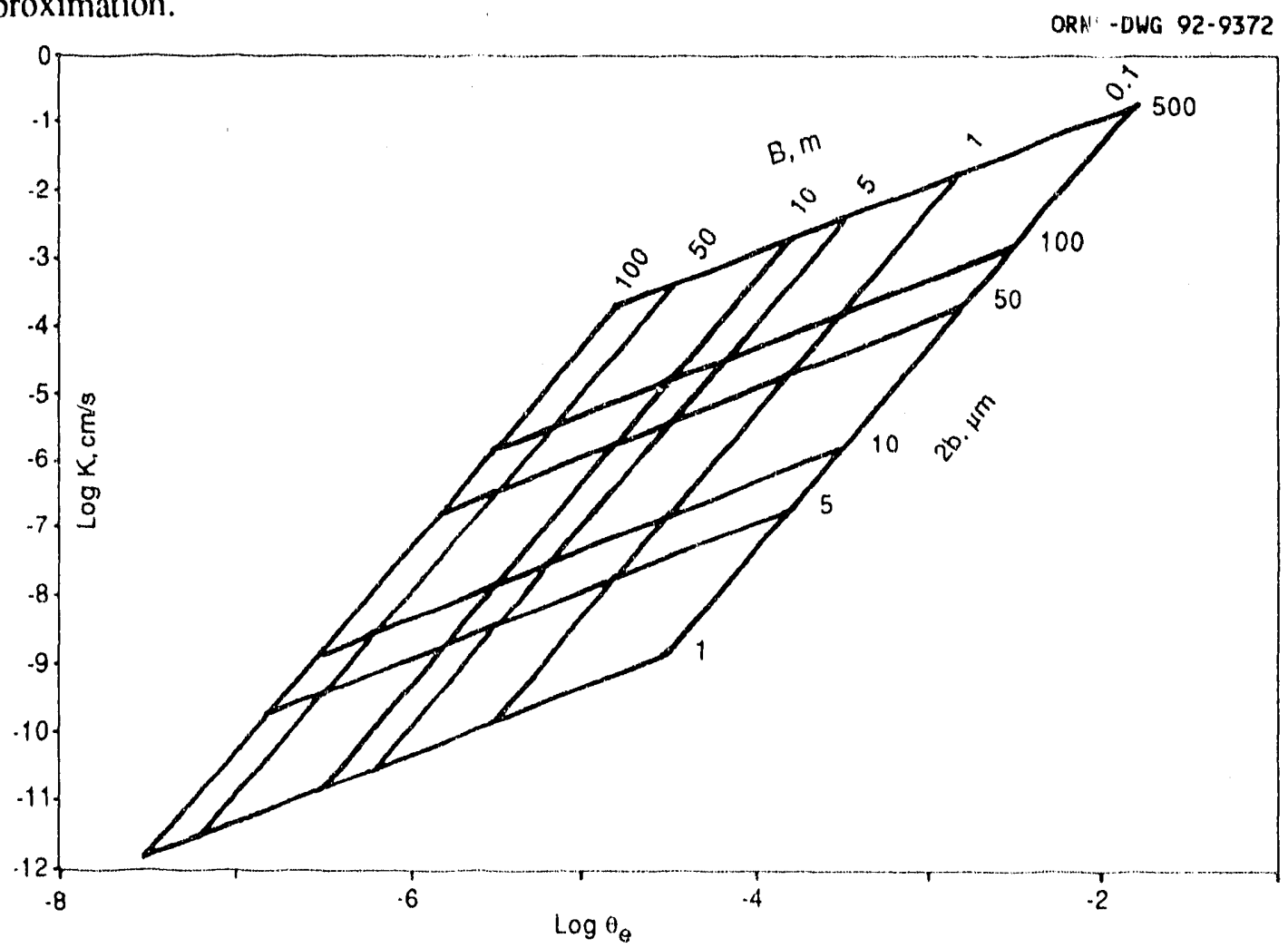

Fig. 3.2. Relationship among $b, B, K_{b u l k}$, and $\theta_{e}$.

\subsection{CHARACTERISTICS OF HYDROLOGIC ZONES}

Subsurface materials of the ORR can be hydrologically classified into a near-surface stormflow zone, a vadose (unsaturated) zone, a groundwater zone, and an aquiclude (see Fig. 2.1). Processes that control water flux and contaminant migration rates, along with 
parameter values for each hydrologic zone are described in this section. These processes give rise to hydrologic concepts that have important implications for waste management, environmental monitoring, and environmental restoration.

\subsubsection{Characteristics of the Stormflow Zone}

The stormflow zone approximately corresponds to the root zone of vegetation and is observed to be thickest in fertile, well-developed, and densely vegetated soils. Average thickness is $\sim 80-120 \mathrm{~cm}$, and the average saturated thickness after a large rainfall event may be as much as $70 \mathrm{~cm}$. Tests of regolith developed on the Dismal Gap Formation (Davis et al. 1984) showed a range in porosity of $0.3-0.63$, a mean porosity of 0.50 , and an average composition of $36 \%$ sand, $22 \%$ silt, and $42 \%$ clay. These results are similar to those of Rothschild et al. (1984) and probably are typical of most regolith of the Conasauga Group and the Chickamauga Group. The average composition of regolith on the Knox Group (Peters et al. 1970) is 58\% silt, $27 \%$ sand, and $15 \%$ clay; the average total porosity is 0.30 .

The occurrence of a perched water table in the stormflow zone was recently studied in the headwaters area of Melton Branch near ORNL. Stormflow monitoring tubes were installed at 17 locations (Fig. 3.3). All monitoring tubes had water inflows, indicating a zone of saturation during some rainfall events, but tubes on steep slopes and in gullies generally had water inflows during small events, whereas larger or more intense events were required to produce inflows to tubes near a drainage divide and on smooth and shallow slopes. There was no detectable correlation between topographic elevation and the frequency, peak level, or duration of water in the monitoring tubes. Instead, local responses of the monitoring tubes are apparently determined by the relative permeabilities of the stormflow and vadose zones, upslope drainage area, surface slope, and nearby convergent or divergent flow paths. 


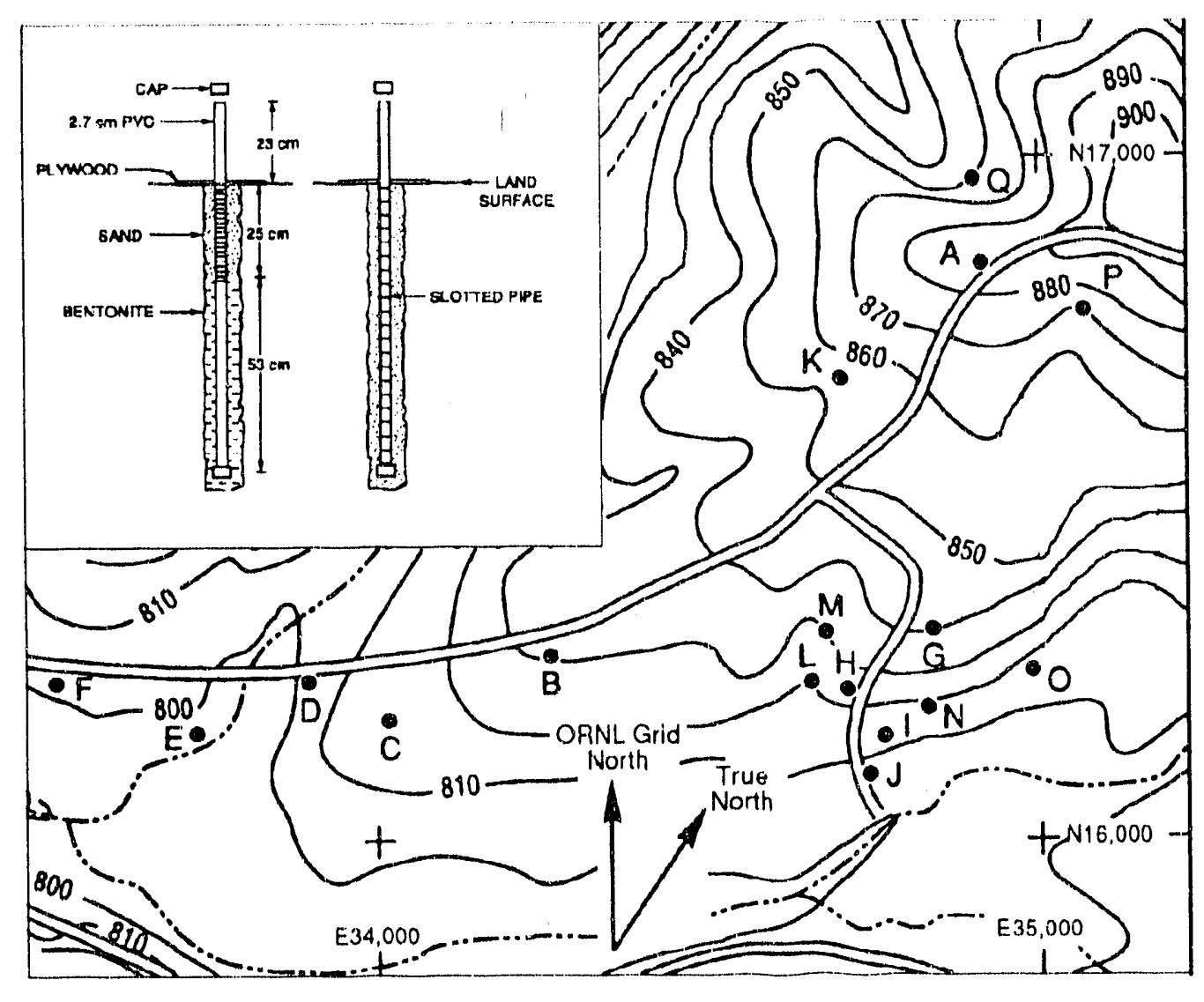

0

$500 \mathrm{H}$

Fig. 3.3. Locations of stormflow monitoring tubes in the study area in headwaters of Melion Branch. Inset shows design of monitoring tubes for collection of water samples (left) and monitoring of water levels (right).

Water levels were monitored in five of the stormflow monitoring tubes in the headwaters of Melton Branch. During all but the largest events, a perched water table and lateral flows of water occurred in only a part of the drainage area. Water levels in the stormflow monitoring tubes peak within 1--3 h of peak rainfall intensity during the nongrowing season. There are fewer responses and more delayed responses to rainfall events during the growing season, attributed to larger soil water deficits. Some monitoring tubes fill to land surface during periods of intense precipitation. At these times and locations, the stormflow zone has filled to overflowing, thereby producing overland runoff. Direct observations indicate that overland runoff is limited to gullies and ravines on hillslopes and is commonly limited to areas near streams at lower elevations in the areas of the Conasauga and Chickamauga aquitards. However, depression water storage is occasionally observed over entire bottomland fields following a large rainfall event. 
Source areas and other wet-weather springs begin to flow as a result of saturated conditions in the stormflow zone, and the lengths of flowing stream channels increase. The density of perennial streams is $\sim 1.8-2.2 \mathrm{~km} / \mathrm{km}^{2}$ in the Whiteoak Creek and Bear Creek basins. In contrast, drainage density is $\sim 8.3 \mathrm{~km} / \mathrm{km}^{2}$ near the time of a large hydrograph peak;

flowing streams extend up ravines to points near drainage divides, and average path length (distance from a drainage divide to a stream) is $\sim 60 \mathrm{~m}$. Smaller expansions (and later contractions) of the drainage network occur after smaller rainfall events. During the nongrowing season in the Melton Branch watershed, graphs of log water level stage in the stormflow zone vs time plot as straight lines soon after the hydrograph peaks

(Fig. 3.4). Similarly, a plot of log streamflow rate, in $\mathrm{m}^{3} / \mathrm{h}$, vs time forms a straight line after the end of overland runoff, and the average slope $(0.015 / \mathrm{h})$ of this line is
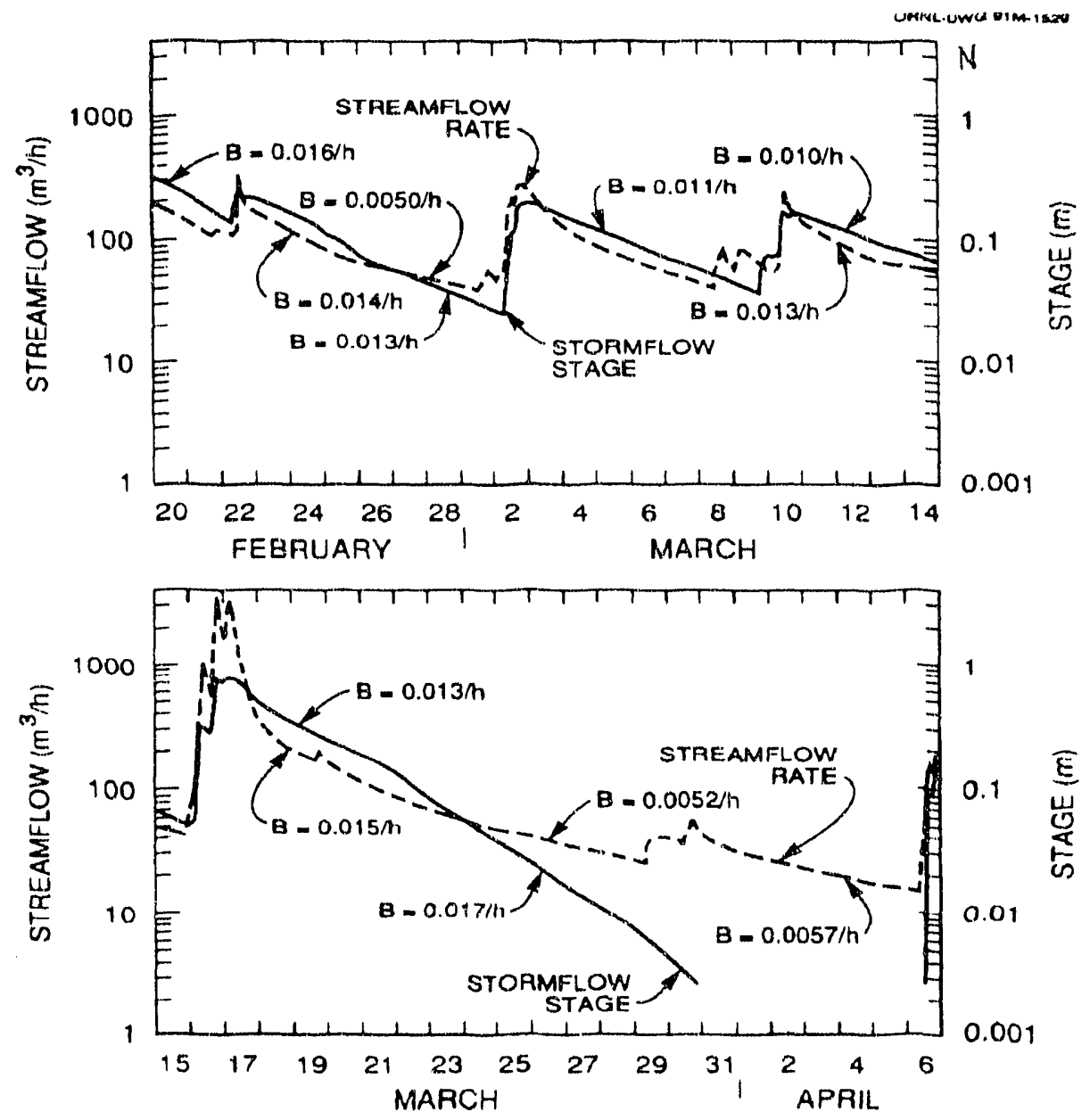

Fig. 3.4. During the nongrowing season in the Melton Branch watershed, graphs of $\log$ water level stage in the stormflow zone vs time plot as straight lines soon after the hydrograph peaks. $B$ is the slope of the recession. 
approximately the same as that of the average stage recession in the stormflow monitoring tubes. After several more days of recession, the streamflow data plot as a curve and then plot as a straight line with an average slope $(0.0050 \mathrm{~m})$ that is nearly the same as that of the average water level recession in observation wells. The close correspondence of the semilog recession rates (Fig. 3.4) suggests that nearly all streamflow at high base flows is produced by discharge from the stormflow zone, whereas discharge from the groundwater zone is dominant at lower base flows, after the stormflow zone has drained. Discharge from the stormflow zone constitutes nearly all streamflow after $15-30 \mathrm{~h}$ of recession from a hydrograph peak, but discharge from the groundwater zone is dominant after $8-10 \mathrm{~d}$ of recession.

Graphs of water level recession in the stormflow zone during the growing season plot as a steepening curve because of water consumption by evapotranspiration (Fig. 3.5). The streanflow recession slopes are also much steeper ard occur sooner than do stage recessions in the stormflow zone. These hydrographs apparently show that the water table in the headwaters of Melton Valley drops below the stream channel during the growing season, and there is little or no discharge of subsurface waters to streams. Natural streamflow during the growing season is nearly all overland runoff from wetland areas during rain events. In areas underlain by the Knox aquifer, there is less overland runoff, and the stomnflow zone rarely fills to overflowing because of larger infiltration rates. Also the water table does not fall below the stream channeis; stormflow discharge is intermittent, but groundwater discharge is continuous through the growing season, thereby sustaining base streamflows. During the nongrowing season, hydrographs show that discharge from the stomflow zone may constiute nearly all streamflow after $10-20 \mathrm{~h}$ of recession from a hydrograph peak, and groundwater discharge is dominant after $6-8 \mathrm{~d}$ of recession in areas underlain by the Knox aquifer.

The specific yield (defined as the drainable porosity) of the stornflow zone, calculated from the average recession rate of streamflow and water level stage, is $0.032-0.036$ in the Melton Branch headwaters area (Moore 1991) and 0.03-0.05 in the Ish Creek basin on westem Chestnut Ridge. These results may be typical of the ORR aquitards and the Knox aquifer, espectively, and are typicai for clay-rich materials that have high residual water contents (Johnson 1967). 

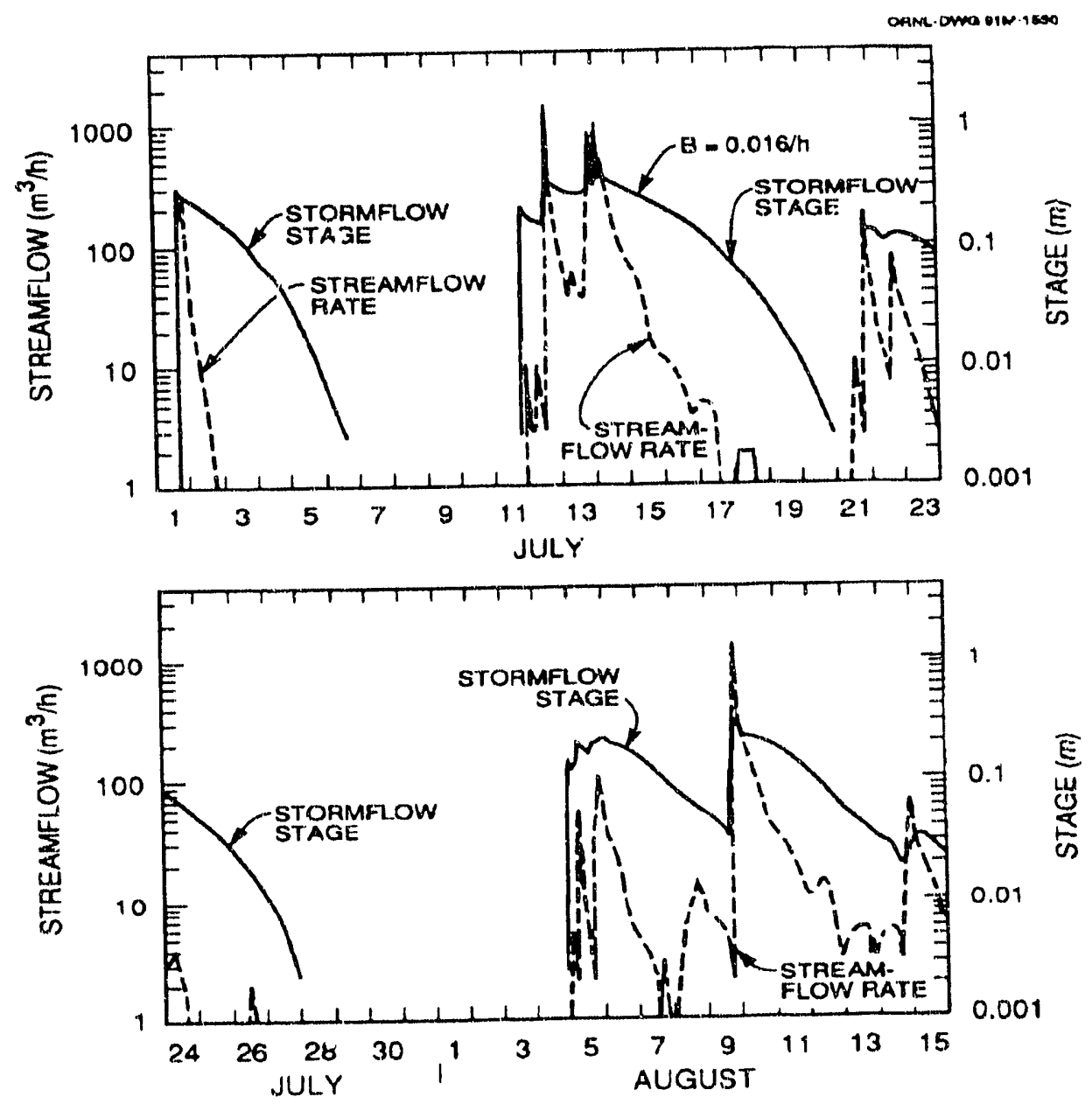

Fig. 3.5. During the growing season, graphs of water-level recession in the stormflow zone plot as a steepening curve because of water consumption by evapotranspiration. $B$ is the slope of the recession.

The majority of the bulk permeability of the stormflow zone results from discrete permeable features, collectively referred to as macropores $(>0.2 \mathrm{~mm}$ in diameter), which constitute only $\sim 0.2 \%$ of the soil volume but account for $96 \%$ of infiltration capacity in forested areas near ORNL (Watson and Luxmoore 1986). Origins of the connected voids include root channels, worm tubes, and aggregation of soil particles. Near the base of the stormflow zone in the aquitards, closely spaced fractures dominate the macroporosity. Average fracture spacings of $\sim 0.5 \mathrm{~cm}$ have been measured in areas of the aquitards (Dreier at al. 1987). The hydraulic conductivity of the stormflow zone in forested areas has been measured by infiltration tests under saturated conditions (Luxmoore et al. 1981; Watson and Luxmoore 1986; Wilson and Luxmoore 1988). A cumulative probability graph of 
these data shows a lognormal distribution (Fig. 3.6). The geometric mean infiltration rate is $0.01 \mathrm{~cm} / \mathrm{s}$, and the range from the mean minus one to the mean plus one standard deviation is $3.7 \times 10^{-3}$ to $2.7 \times 10^{-2} \mathrm{~cm} / \mathrm{s}$. For comparison, the average hydraulic conductivity of forested soils in the headwaters area of Melton Branch was calculated as $0.01 \mathrm{~cm} / \mathrm{s}$ by hydrograph analysis (Moore 1991 ).

Smaller permeabilities occur in sparsely vegetated areas of the ORR. Erosion studies by The University of Tennessee, using a large-area rainfall simulator on grassed areas of WAG 6 near ORNL, measured an average infiltration rate of $1.3 \times 10^{-3}$ (R. B. Clapp, ORNL, personal communication, 1991), for example. This result may be near the

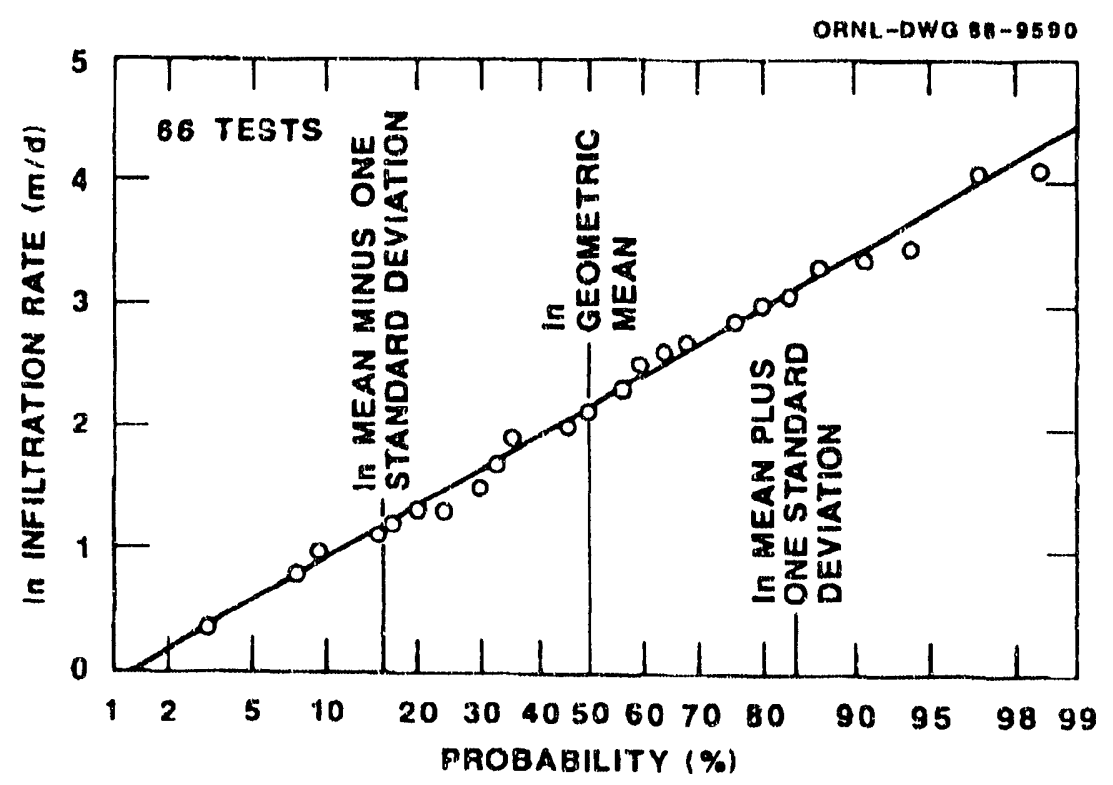

Fig. 3.6. A cumulative probability graph of hydraulic conductivity of the stormflow zone, measured by infiliration tests under saturated conditions, shows a lognormal distribution.

minimum for a large area because maximum 1 - $\mathrm{h}$ precipitation intensity on the ORR is equivalent to $1.8 \mathrm{~m} / \mathrm{d}$ (McMaster 1967), and overland runoff is generally not observed until the stormflow zone has filled to overflowing.

The hydraulic gradient for lateral flow of water in the stormflow zone is determined mostly by the slope of the base of this zone and is nearly the same as the slope of land surface. The maximum slope of the surface on the ORR is generally $<() .3$, although locally the 
steepest part of a slope may be $>0.5$. The average surface slope and thus hydraulic gradient in the stormflow zone is $\sim 0.075$. If hydraulic conductivity is $9.0 \mathrm{~m} / \mathrm{d}$, the average specific discharge for downslope flows in the stormflow zone is $\sim 0.67 \mathrm{~m} / \mathrm{d}$.

Discharge from the stormflow zone is an important component of streamflow on the ORR. Hydrograph analysis in the Melton Branch and Ish Creek basins shows that peak discharge from the stormflow zone is $\sim 80-110 \mathrm{~L} / \mathrm{s} / \mathrm{km}^{2}$ of drainage area, but the discharge decreases to $<10 \mathrm{~L} / \mathrm{s} / \mathrm{km}^{2}$ after $10 \mathrm{~d}$ of recession (Moore 1991). These results may be typical of forested areas on the ORR. Some water also percolates down from the stormflow zone to the water table.

The stormflow zone may be a major pathway for contaminant transport from waste disposal areas on the ORR. Studies of contaminant release to streams during rain events in the Melton Branch watershed indicate that contaminant mass flow, defined as the contaminant mass per unit time, increases dramatically during events. For example, the ${ }^{3} \mathrm{H}$ mass flow in Melton Branch changed from 7 to $>40 \mathrm{Ci} / \mathrm{d}$ in $<6 \mathrm{~h}$ during a January 1988 rain event (Solomon et al. 1991). Similar studies of ${ }^{3} \mathrm{H}$ release to a first-order stream in Solid Waste Storage Area (SWSA) 6 indicate that mass flow increases by a factor of 200 during rain events (Davis et al. 1987). The relative importance of contaminated stormflow discharge compared with contaminated ground water discharge on an annual basis might depend on the operational age of a waste area. For example, in SWSA 6, which has received wastes since 1969 , the stormflow zone may be responsible for $50 \%$ of the total tritium $\left({ }^{3} \mathrm{H}\right)$ release (Davis et al. 1987). However, in SWSA 5, which received wastes primarily from 1959 to 1970 , the stormflow zone may be responsible for $<20 \%$ of the ${ }^{3} \mathrm{H}$ release. Differences in the percentage of release through stormflow in SWSA 5 vs SWSA 6 might reflect the difference in operational age of the two waste areas and, thus, a difference in time available for transport through the vadose zone into the groundwater zone. Alternatively, the difference may be a result of differetices in the physical location of waste sources.

When the stormflow zone saturates during rain events, macropores and mesopores transmit nearly all lateral flow toward streams. Because the macroporosity is small, very large transport velocities occur. For example, during a recent test in the stormflow zone in the headwaters area of Melton Branch, the first arrival of a bromide tracer injected near a ridge top during a rain event was $\sim 4 \mathrm{~h}$ in subsurface soil pans $\sim 50 \mathrm{~m}$ downslope (P. M. Jardine, 
personal communication). This transport velocity of $>12 \mathrm{~m} / \mathrm{h}$ is probably typical of the stormflow zone overlying the ORR aquitards.

Although rapid transport occurs in the stormflow zone, the amount of contaminant transported is small because of advective-diffusive exchange between macropores and mesopores and less permeable micropores. The effects of exchange on contaminant transport have been studied in highly controlled experiments conducted on a soil pedon in the Walker Branch experimental watershed. The experiment and its design is described by Jardine et al. (1990) and consists of two sets of soil-solution samplers designed to collect pore waters from two distinct sizes of pores. $\mathrm{MgBr}_{2}$ was instantaneously applied at the surface, and the downward transport of $\mathrm{Br}^{-}$was then monitored for $375 \mathrm{~d}$. Because of its anionic form, $\mathrm{Br}^{-}$is thought to be nearly geochemically conservative at the Walker Branch site. Figure 3.7 shows the $\mathrm{Br}^{-}$concentration observed at a depth of $85 \mathrm{~cm}$ as a function of time. Bromide was first detected in the large pores during the first major rain event

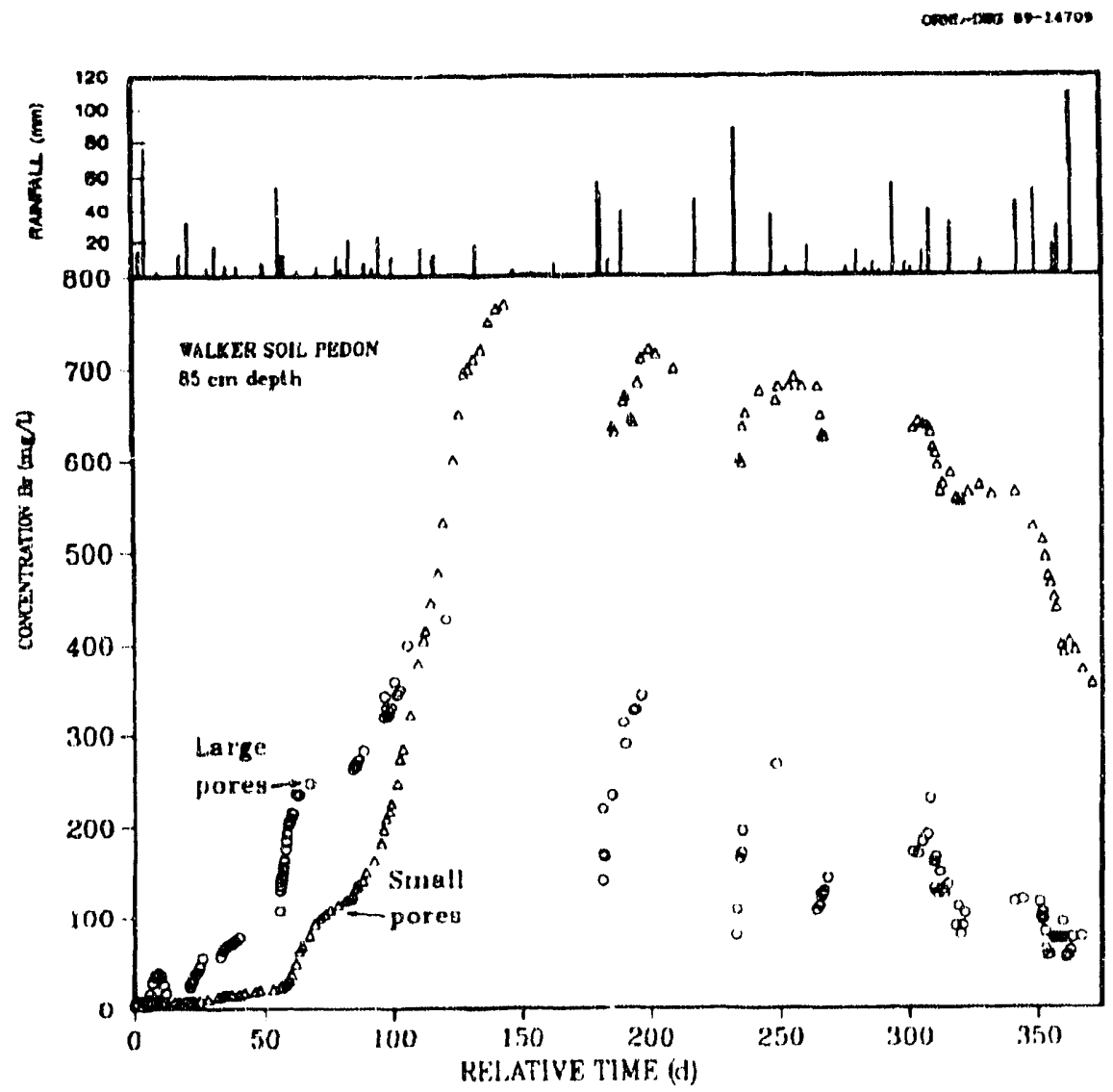

Fig. 3.7. Br- concentration observed at a depth of $85 \mathrm{~cm}$ as a function of time. 
after the application; however, $100 \mathrm{~d}$ were required to reach peak $\mathrm{Br}$ concentrations, which were $\sim 50$ times lower than the concentration applied at the surface. Bromide concentrations in the smaller pores remained low for $>50 \mathrm{~d}$, then rose steadily and reached a peak after $\sim 150 \mathrm{~d}$ with the peak concentration being $\sim 2$ times larger in the small pores than in the larger pores. After $375 \mathrm{~d}$ the $\mathrm{Br}^{-}$concentration in the small pores had declined to only $\sim 50 \%$ of the peak value. If mass were being transported only in the larger pores with little interaction with smaller pores, very large concentrations would have occurred during the first rain event. The observed attenuation of $\mathrm{Br}$ as well as the persistence of high $\mathrm{Br}^{-}$ concentrations in small pores illustrates the effectiveness of the matrix diffusion process as a dynamic mechanism for storage and release of solutes.

The concept of a large water flux occurring in the stormflow zone is supported by a variety of observations and measurements. However, most of these estimates of contaminant flux in the stormflow zone are inferred from measurements in streams during storms. Because primary contaminant sources are generally located beneath the stormflow zone (for example, waste trenches generally extend to depths of $\sim 5 \mathrm{~m}$ ), the mechanisms for delivering contaminants into the stromflow zone are not well docurnented. In cases where trenches fill to overflowing, contaminants are injected directly into stormflow; however, a relatively small number of trenches have been observed to overflow during storms. An alternative hypothesis is that contaminants may be transported from primary sources via groundwater to riparian arsas bordering streams (where groundwater and stormflow begin to converge). Vertical advectiv -diffusive transport might then deliver contaminants into the stormflow zone for rapid transport to streams.

\subsubsection{Characteristics of the Vadose Zone}

The vadose zone commonly is within the regolith, but it includes weathered and fresh rock in many areas. No differences have been recognized in the hydrologic characteristics of residuum, colluvium, and alluvium. The thickness of the vadose zone is determined by depth to the permanent water table. The October depth to water in wells has a range of $0.2-22 \mathrm{~m}$ in the Conasauga and Chickamauga aquitards; the geometric mean depth is $4.1 \mathrm{~m}$ (Moore 1988). The typical October depth to the water table in areas underlain by the Knox aquifer is $0.2-45 \mathrm{~m}$. The deepest recorded water level measured on the ORR is $88 \mathrm{~m}$ below land surface in a well in the Knox aquifer, near the top of Melton Hill (McMaster and Waller 1965). 
Recharge to the water table occurs nearly everywhere, but the amount and rate are limited by the vertical permeability of the vadose zone and by spatial and temporal differences in the saturated thickness of the stormflow zone. The total porosity of this zone is probably the same as in the stormflow zone $(0.3-0.5)$. The calculated average effective porosity of the vadose zone (4.2 $\times 10^{-3}$; Moore 1989) is nearly the same as the specific yield of the groundwater zone and is about an order of magnitude smaller than the specific yield of the stormflow zone, indicating that vertical percolation through this zone occurs in only a few permeable features such as fractures. Measurements of permeability in the vadose zone indicate a large range, as is discussed later, and local recharge characteristics should also vary over a large range. Measurements of saturated hydraulic conductivity have been made by infiltration and packer tests in the vadose zone, and these data are lognormally distributed. The geometric mean of hydraulic conductivity is $1.9 \times 10^{-3} \mathrm{~m} / \mathrm{d}$, and the range from the mean minus one to the mean plus one standard deviation is $1.74 \times 10^{-7}$ to $1 \times 10^{-4} \mathrm{~cm} / \mathrm{s}$ (Moore 1989).

Measurements and observations in the ORR demonstrate that following recharge events, saturated flow commonly occurs along discrete features within the vadose zone. The cherty clay derived from weathering of Knox bedrock is different from the saprolite and clay derived from weathering of the Conasauga Group, but saturated flow occurs in the vadose zone of both.

Residuum of the Knox aquifer contains chert fragments from sand to boulder size as well as semicontinuous relict beds of fractured chert. These materials also contain dessication fractures and slickensided settlement fractures. Lithologic inhomogeneities, including bodies of silt that are saprolitic remains of bedrock blocks, occur throughout. The inhomogeneities provide a network of weakly connected openings through which saturated flow can occur. The material has high water retention characteristics and at depths of more than several meters is continuously near saturation (Kete!!e and Huff 1984). In piezometer clusters to depths of $10 \mathrm{~m}$ in residuum thicker than $30 \mathrm{~m}$, seasonal saturation occurs above the permanent water table. The onset of saturation in these soils typically occurs when winter precipitation pattems begin. The disappearance of saturation typically occurs in the spring when evapotranspiration increases.

Saprolite derived from shale and siltstone of the Conasauga generally ranges up to $\sim 10 \mathrm{~m}$ thick and is capped by thin sandy to silty clay. The saprolite retains primary bedrock texiures and features, including fractures. Carbonate-rich beds tend to weather more 
deeply than more clastic beds. Porosity is greater than that of the unweathered bedrock. Observation of seepage entering excavation walls in shale/siltstone saprolite masses through relict bedding planes and weathered limestone beds after soaking precipitation events demonstrates the occurrence of saturated flow through fractures in the saprolite of the vadose zone.

Temporal changes in recharge rates are spatially variable and apparently depend mostly on water table depth and the local hydraulic conductivity of the vadose zone. Water levels in some wells begin to rise within $1 \mathrm{~h}$ of peak precipitation intensity. At the other extreme, delays as long as $45 \mathrm{~d}$ occur in a few wells (Moore 1989). Recharge rates may dramatically decrease after a period of $1-4 \mathrm{~d}$ in most areas but can continue at low rates for periods of as long as $30 \mathrm{~d}$. The maximum daily water level rise in response to recharge is $\sim 0.2-2 \mathrm{~m}$ for most wells in the Conasauga and Chickamauga aquitards. The lower end of this range is typical for most wells in the Conasauga Group, whereas only a few wells in the Chickamauga Group show maximum daily rises near the upper end of the range. There are few detailed hydrographs for wells in the Knox aquifer, but calculations indicate that the maximum water level rise is $\sim 2.0 \mathrm{~m} / \mathrm{d}$.

Annual recharge through the vadose zone has been calculated from an analysis of well and stream hydrographs and by calibration of numerical models of flow in the groundwater zone. Assuming that recharge to the water table occurs during discrete small periods after rain events (i.e., that rapid drainage of the vadose zone occurs) and assuming that during such events the recharge flux is much greater than groundwater discharge, a change in the position of the water table can be used to calculate recharge. Inspections of water level hydrographs for wells in the Conasauga and Chickamauga aquitards indicate that $\sim 80 \%$ of the annual recharge and $60 \%$ of the discharge occur in the 6-month period from midOctober to mid-April (Moore 1989). The net increase in water storage during this period causes a water table rise from the seasonal low to the seasonal high. Average annual recharge to the water table can be calculated from these proportions (Moore 1991):

$$
\begin{aligned}
& (0.8 Q-0.6 Q)=S_{y} s \\
& Q=5 S_{y} s,
\end{aligned}
$$

where $Q$ is annual groundwater recharge, $S_{y}$ is specific yield near the water tuble, and $s$ is the average seasonal rise in the water table. As is discussed later, the average specific yield near the water table in the Conasauga and Chickarnauga aquitards is $\sim 0.0025$. Thus, 
average annual recharge to the aquitards is $\sim 2.0 \mathrm{~cm}$ of water. Using the same specific yield for the Knox aquifer and assuming the same proportions of recharge and discharge during the period, average annual recharge is $\sim 6 . \mathrm{cm}$ of water.

Both areal and cross-sectional models of flow in the groundwater zone have been developed for Bear Creek Valley and Melton Valley (Bailey and Lee 1989; Geraghty and Miller 1989; Tucci 1986; Zehner and Tucci 1991). In all of these models, recharge is spatially variable and occurs near ridge tops. When averaged over the entire water table surface, recharge estimates for Bear Creek Valley range from $1.2 \mathrm{~cm} / \mathrm{year}$ (Bailey and Lee 1989 ) to $30 \mathrm{~cm} /$ year (Geraghty and Miller 1989). However, recharge estimates from modeis depend heavily on estimates of hydraulic conductivity and the $30 \mathrm{~cm} /$ year estimate resulted from a hydraulic conductivity that was $\sim 20$ times larger than the geometric mean value. Average model recharge values for Melton Valley range from $2-5 \mathrm{~cm} /$ year (Zehner and Tucci 1991).

Assuming an average daily water table rise of $0.15 \mathrm{~m}$ in response to major storm events and an average specific yield of $2.5 \times 10^{-3}$ (as discussed later) near the water table, the average daily recharge during storm periods is $0.04 \mathrm{~cm} / \mathrm{d}$ in areas of the ORR aquitards. Thus, if recharge occurred only along discrete saturated features during storm periods, such fearures would have to be saturated for $50-100 \mathrm{~d}$ each year to account for an annual recharge of $2-5 \mathrm{~cm}$. Because a quantitative evaluation of saturated features in the vadose zone has not been done and because some uncertainty exists in estimates of specific discharge, it is possible that a portion of recharge results from more delayed unsaturated flow. A more complete analysis of rapid vs delayed recharge is an important task and will require estimates of the relationships between hydraulic conductivity and degree of saturation for materials in the vadose zone. If rapid recharge occurs during rain events, contaminant transport in the vadose zone is along complex pathways that are controlled by the distribution of permeable features. Transport mechanisms such as matrix diffusion are probably important in the vadose zone, however such processes are not well characterized in this zone.

Nearly all waste disposal excavations on the ORR extend into the vadose zone; the bottoms of waste trenches and silos are generally near the water table. Water inflows to wastes occur from a combination of infiltration during rain events and lateral stormflow from upslope areas. Waste, fill, and cover materials are more permeable than is regolith in undisturbed areas. Tests in WAG 6 near ORNL, for example, showed that the geometric 
mean of infiltration rate for cover materials between experimental trenches was 10 times larger than that of undisturbed weathered shale (Davis et al. 1984). Furthermore, lowpermeability layers can form as a result of an accumulation of fine (silt and colloidal-size) materials on the bottom of excavations (Solomon and Switek 1986). Thus, buried waste excavations in most areas act as both infiltration basins and subsurface reservoirs for water. Water levels in trenches are consistently higher than in wells tapping the groundwater zone immediately adjacent to trenches. Although it is possible that a perched water table exists in some trenches, numerical modeling results suggest that a water table mound rather than a perched water table exists for most trenches (Solomon and Yeh 1987).

\subsubsection{Characteristics of the Groundwater Zone}

The permanent water table typically is near the transition from regolith to bedrock at depths of $<1-45 \mathrm{~m}$. As subsequently discussed, changes in hydraulic parameters and changes in major ion chemistry with depth suggest subdivision of the groundwater zone into three intervals: (1) a water table interval, (2) an intermediate interval, and (3) a deep interval. The depth and thickness of these intervals vary, especially between the ORR aquitards and the Knox aquifer.

A thin ( 1-3 m thick) permeable interval may be present near the water table, as illustrated below. Spatial and temporal differences in the saturated thickness and

ORNL - DWG $92-9374$

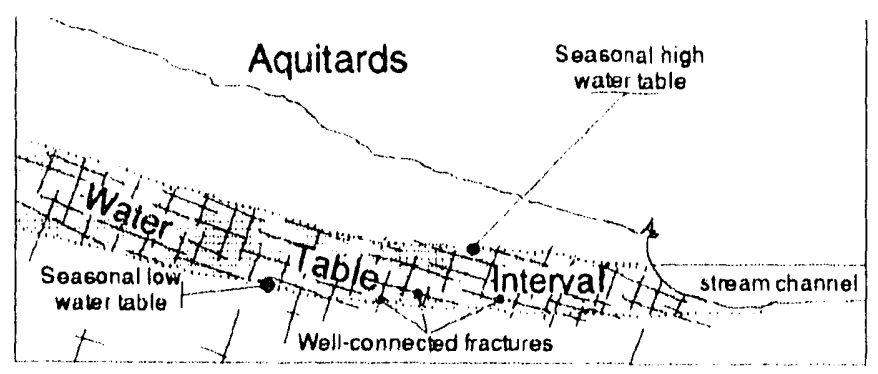

transmissivity of this interval explain both the configuration of the water table and most of the fluctuations in groundwater discharge to streams. The water table is near the contact between regolith and weathered bedrock because a large water flux has formed regolith at shallower levels by solution of the rock cement; fresh bedrock at deeper levels indicates a smaller water flux. Seasonal declines in water table elevation can nearly drain this interval. The resulting changes in transmissivity explain an order of magnitude fluctuation in 
groundwater discharge rates even though contours of water table elevation at the times of annual high and low water levels show little change in hydraulic gradients.

Changes in saturated thickness with the inverse of hydraulic gradient from one topographic location to another explain the common observation that the water table is a subdued replica of land surface, because the product of transmissivity and hydraulic gradient is nearly constant at all locations along any flow path. The concept of a thin water table interval is new, and detailed studies designed to directly define this interval have not been conducted.

Hydrograph analyses show that specific yield near the top of the groundwater zone is $\sim 2.5 \times 10^{-3}$ in the headwaters area of Melton Branch (Moore 1991) and $\sim 3.3 \times 10^{-3}$ in the Ish Creek basin. These results are nearly the same and may thus be typical for the entire ORR. Storativity determined from aquifer tests is lognormally distributed (Fig. 3.8); the geometric mean of storativity is $8.4 \times 10^{-4}$. The range in storativity from the geometric mean minus one to the mean plus one standard deviation is $4.8 \times 10^{-5}$ to $5.8 \times 10^{-3}$.

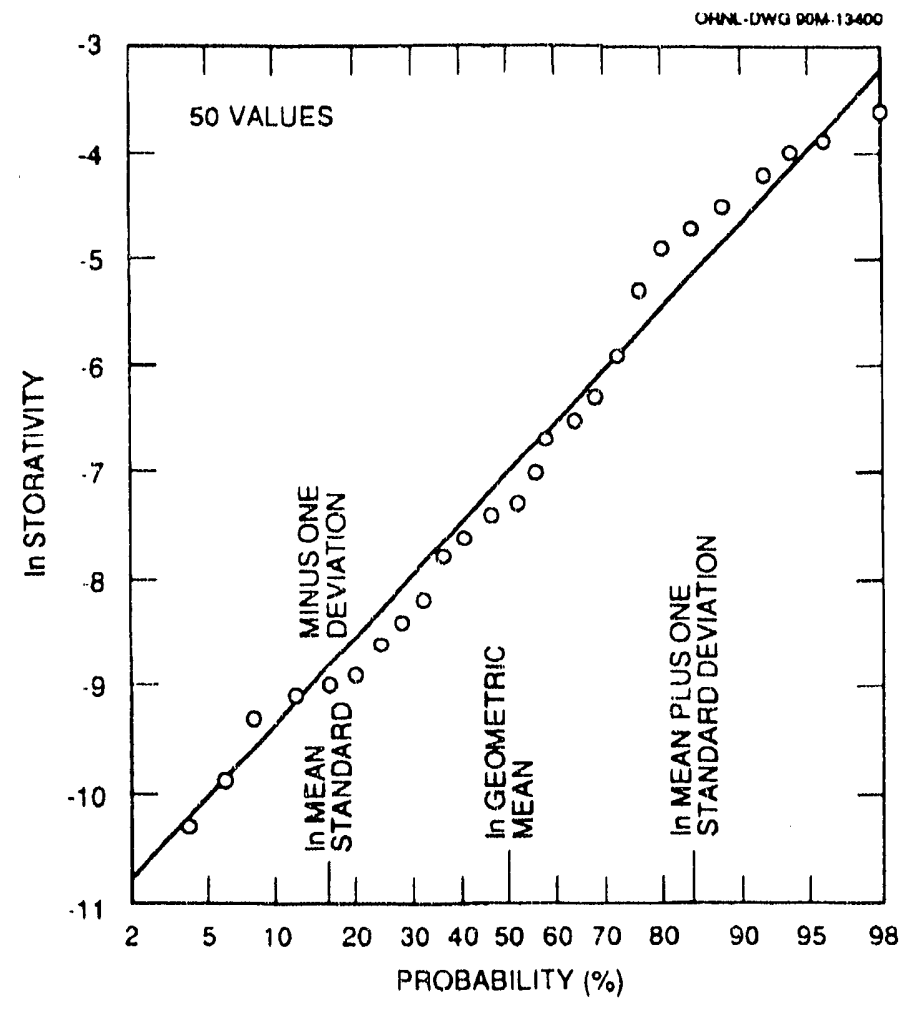

Fig. 3.8. Storativity determined from aquifer tests is lognormally distributed. 
The hydrograph analyses also indicate that the maximum rates of groundwater discharge to streams are $\sim 4.7 \mathrm{~L} / \mathrm{s} / \mathrm{km}(0.017 \mathrm{~mm} / \mathrm{h})$ in areas of the ORR aquitards and $17 \mathrm{~L} / \mathrm{s} / \mathrm{km}(0.062$ $\mathrm{mm} / \mathrm{h}$ ) in areas of the Knox aquifer. Most of this discharge may be from the permeable layer at the water table (Moore 1991). During the nongrowing season, groundwater discharge from the ORR aquitards is approximately equal to discharge from the stormflow zone after $\sim 8 \mathrm{~d}$ of recession from a large hydrograph peak and constitutes nearly all streamflow after $\sim 14 \mathrm{~d}$ of recession (Moore 1991). Dis sharge from the Knox aquifer is approximately equal to discharge from the stormflow zone after $\sim 3 \mathrm{~d}$ of recession from a large hydrograph peak and constitutes nearly all streamflow after $\sim 10 \mathrm{~d}$ of recession.

The intermediate interval of the groundwater zone consists of relatively permeable fractures (or possibly fractured regions) in a relatively impermeable matrix. Sixty tests with an electromagnetic borehole flowmeter showed that the average thickness (vertical dimension) of the permeable regions is $\sim 70 \mathrm{~cm}$. These results suggest that permeable regions are commonly developed within a single layer of rock, and the average thickness of a permeable region (assuming an average dip of $35^{\circ}$ ) is $<60 \mathrm{~cm}$. Well logs and an analysis of the depths of paired shallow and deeper wells (that are screened in permeable regions as determined by yield during construction) show that the vertical spacing between permeable regions increases from $7 \mathrm{~m}$ just below the water table interval to $>35 \mathrm{~m}$ at depths $<60 \mathrm{~m}$. A cumulative probability graph of transmissivity data (Fig. 3.9) shows two lognormal populations. The population at the upper right on the graph represents permeable intervals, and the geometric mean of transmissivity is $0.23 \mathrm{~m}^{2} / \mathrm{d}$. The population at the lower left represents matrix intervals, and the geometric mean of transmissivity is $0.0011 \mathrm{~m}^{2} / \mathrm{d}$. If the borehole flowmeter surveys are interpreted to show that permeable intervals have an average thickness of $0.60 \mathrm{~m}$ and if the matrix intervals are assumed to be uniformly relatively impermeable, then the hydraulic conductivity of the permeable intervals is $>1000$ times larger than that of the rock matrix. 


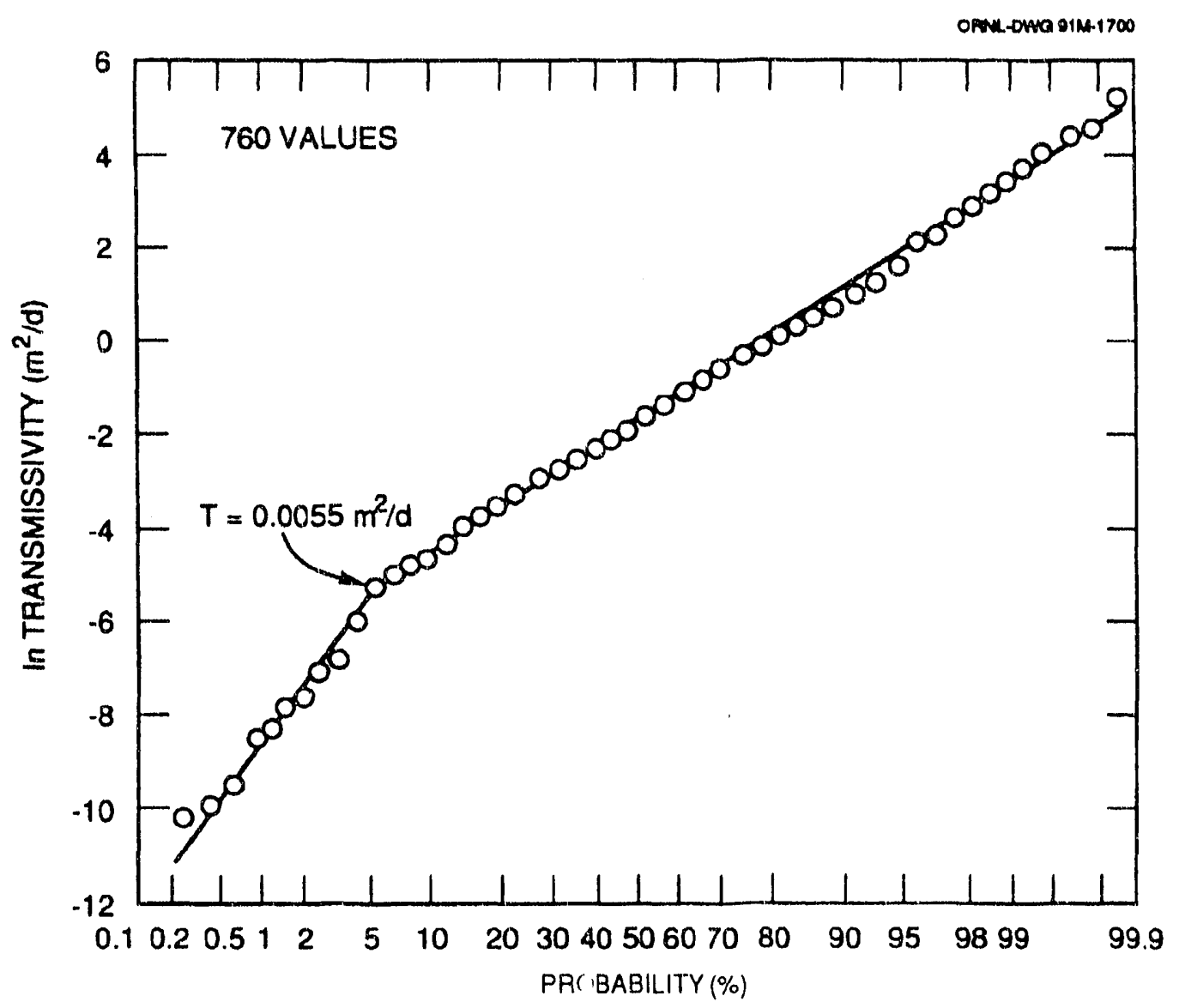

Fig. 3.9. A cumulative probability graph of transmissivity data shows two lognormal populations.

The statistical analysis of transmissivity shown in Fig. 3.9 has not been corrected for biases caused by screen length and well depth. Transmissivity values may be too small if a screen length is less than the thickness of the permeable interval and may be too large if the screen spans more than one permeable interval. A decrease in average transmissivity of the aquitards at deeper levels has been noted in several studies (Connell and Bailey 1989; Moore 1988; Webster and Bradley 1987). Data for Bear Creek Valley show that the geometric means of transmissivity are smaller than that of the population for screen lengths $<2 \mathrm{~m}$ and are larger than that of the population for screen lengths $>12 \mathrm{~m}$.

A classification of the same data by depth of the screened interval shows that the geometric means and the two-standard-deviation ranges of transmissivity are approximately the same at depths of $<100 \mathrm{~m}$, but these values decrease at deeper levels. Thus, a statistical determination of transmissivity for the purpose of calculating groundwater flow at shallow 
depths should omit values from depths $>100 \mathrm{~m}$ and from wells in which screened intervals are $<2 \mathrm{~m}$ and $>12 \mathrm{~m}$.

The geometric mean of transmissivity for depths $<100 \mathrm{~m}$ and for screened intervals $>2 \mathrm{~m}$ and $<12 \mathrm{~m}$ in Bear Creek Valley is $0.58 \mathrm{~m}^{2} / \mathrm{d}$. This value is $\sim 70 \%$ larger than that for the entire population in Bear Creek Valley. The previous analysis cannot be completed for all wells in areas of the ORR aquitards because $~ 70 \%$ of all well screens are the same $(\sim 3 \mathrm{~m})$ length. However, assuming that the transmissivity corrections in Bear Creek Valley apply to the entire ORR aquitards, the geometric mean of transmissivity for permeable intervals at shallow depths in the ORR aquitards is $0.33 \mathrm{~m}^{2} / \mathrm{d}$.

Groundwater flow in the Knox aquifer is dominated by a few cavity systems. Two wells on the southeast side of Bear Creek Valley are reported to produce $>60 \mathrm{~L} / \mathrm{s}$ of water, and about a dozen large springs discharge water near the base of ridges underlaid by the Knox aquifer. Also, a tracer test in the Knox aquifer showed a fluid velocity of $200-300 \mathrm{~m} / \mathrm{d}$ between a swallow hole and a resurgent spring farther downstream (Ketelle and Huff 1984). However, most existing wells in the Knox aquifer yield small quantities of water $(<1 \mathrm{~L} / \mathrm{min})$ and do not represent conditions in the most permeable regions. A statistical analysis of transmissivity data shows a geometric mean value of $2.3 \times 10^{-3} \mathrm{~cm}^{2} / \mathrm{s}$ with a mean minus one standard deviation of $3 \times 10^{-4} \mathrm{~cm}^{2} / \mathrm{s}$ and a mean plus one standard deviation of $2.2 \times 10^{-2} \mathrm{~cm}^{2} / \mathrm{s}$. Although the number of transmissivity estimates in the Knox $(n=42)$ is less than in the ORR aquitards $(n=145)$, the available data suggest that the bulk permeability in the Knox is ten times greater than the ORR aquitards. However, locally the Knox is very permeable and is capable of transmitting large quantities of water.

In areas of the ORR aquitards, the average hydraulic gradient on cross-valley sections is $\sim 0.05$, but hydraulic gradients $>0.1$ occur on steep hillslopes, whereas gradients $<0.01$ occur in floodplains. Along-valley hydraulic gradients average -0.005 in relatively flat areas, but gradients in the range $0.01-0.06$ occur close to cross-cutting, tributary streams. Assuming that the average thickness of permeable intervals is $0.8 \mathrm{~m}$ (as given by the borehole flowmeter results), the average hydraulic conductivity of permeable intervals, computed using average transmissivity data, is $0.4 \mathrm{~m} / \mathrm{d}$. Assuming an average hydraulic gradient of 0.05 , the average specific discharge in permeable intervals of the intermediate groundwater zone in the ORR aquitards is $\sim 11 \mathrm{~m} /$ year. The water table is deeper beneath ridges in areas of the Knox aquifer, and the average hydraulic gradient toward nearby 
streams is $\sim 0.01-0.03$. Assuming an average hydraulic conductivity that is ten times greater than the ORR aquitards, the average specific discharge in the Knox aquifer is $\sim 45 \mathrm{~m}$ /year.

Below the water tuble interval, most groundwater flows along permeable fracture networks within layers of rock. In any thin but areally extensive network of permeable fractures, groundwater may flow either downdip or nearly horizontally along strike. Under steep ridge slopes, where vertical hydraulic gradients are significant, groundwater may flow downdip as well as along strike. Beneath valley slopes, where vertical hydraulic gradients are small or oriented upward, most groundwater probably flows along strike within permeable fracture networks toward discharge locations in cross-cutting, tributary streams, as illustrated below.

\section{Aquitards}

ORNL -DWG $92-9375$

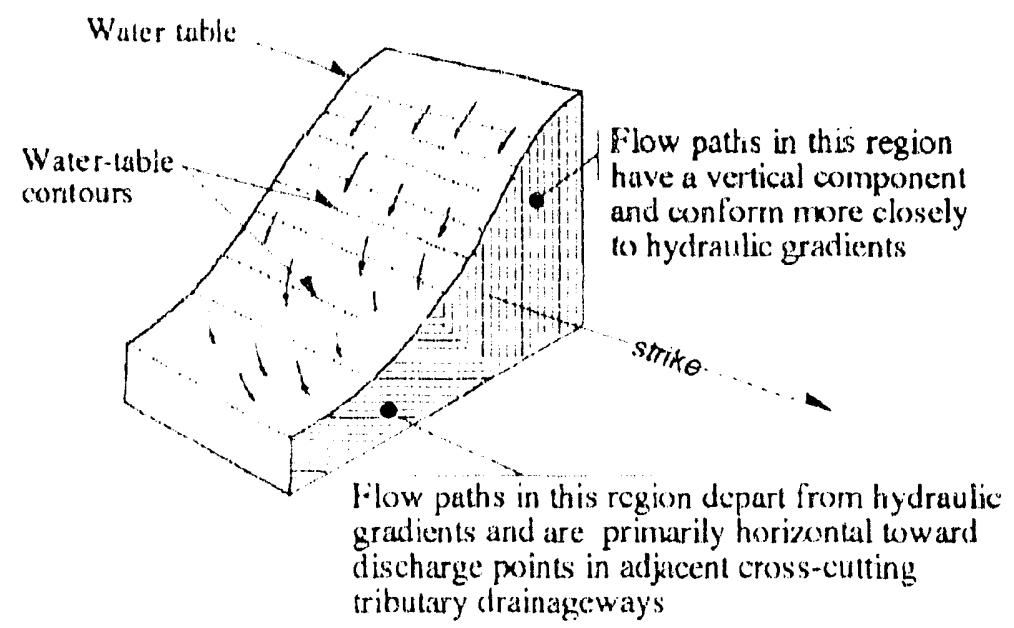

The remaining water may flow downdip to locations beneath main valley streams and then seep upward through much less permeable matrix materials to discharge locations in these streams. Elongated cones of depression during numping tests and first arrivals of tracers in wells located along geologic strike from the point of injection have been interpreted in some previous studies as indicating anisotropy and a rock mass that is more permeable in the along-valley direction than in the cross-valley direction. Instead these observations and measurements may be explained by the orientation of the beds and the fracture networks; flow paths within these networks have a much larger average permeability than do flow paths across matrix intervals from one fracture network to another. Although observed strike-preferential flow paths can be explained without evoking anisotropy within 
individual permeable zones, small-scale fold axes oriented parallel to strike conceptually can result in enhanced premeability in the along-strike direction. A more complete understanding of strike-preferential flow paths is an important task because of the need to locate primary contaminant sources by tracing back to them from contaminant seeps and stream discharge points.

The information shown earlier on Fig. 3.2 suggests effective fracture spacings in the intermediate interval that are between 0.1 and $10 \mathrm{~m}$ and fracture apertures that range from 10 to $50 \mu \mathrm{m}$. However, the recent borehole flow measurements suggest vertical fracture spacings of $\sim 7 \mathrm{~m}$ near the water table, which constrains fracture apertures to lie within the range of $\sim 30$ to $50 \mu \mathrm{m}$.

Identification of a deep $\mathrm{g}$ "oundwater interval is based on limited hydraulic and geochemical data from borehole depths ranging from 30 to $300 \mathrm{~m}$. Hydraulic conductivity data come primarily from straddle packer tests (King and Haase 1988) and are supplemented by slug tests and slow-recovery analysis (Dreier and Toran 1989). In general, the intermediate groundwater interval shows hydraulic conductivities that are $>10^{-6} \mathrm{~cm} / \mathrm{s}$. The deep groundwater interval shows conductivities that are as high as in the intermediate range; however, measured conductivities in this interval are also as low as $10^{-9} \mathrm{~cm} / \mathrm{s}$ (Fig. 3.10 ). The low conductivities may be the result of either reduced matrix permeability or increased fracture spacing. The high conductivities presumably occur when the tested interval intersects a permeable fracture. 
PACKER TEST RESULTS; BETHEL VALLEY CHICKAMAUGA AQUITARD

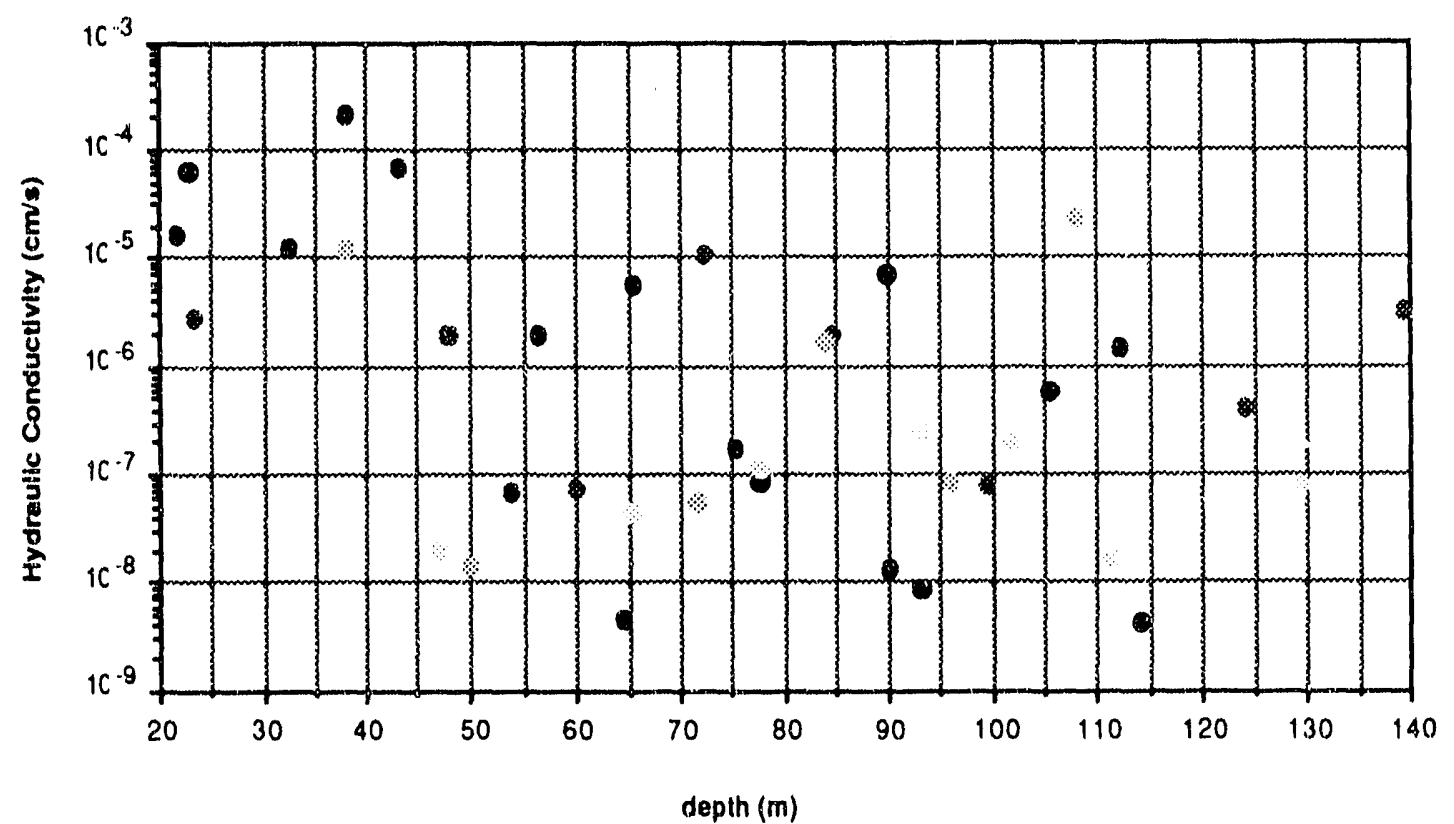

Fig. 3.10. Straddle packer test results from boreholes collared in the Chickamauga aquitard. Dot patterns correspond to individual wells.

Median hydraulic conductivity values for intermediate and deep intervals at several localities around the ORR are shown in Table 3.1. Other characteristics of the deep groundwater interval include a limited and delayed response to precipitation events, whereas available data suggest that the intermediate interval shows a marked response to precipitation (Dreier and Toran 1989). In addition, where tested, water samples from the deeper interval show higher electrical conductance (Dreier and Toran 1989) or higher total dissolved solids content (Dreier et al. in preparation), reflecting a longer residence time in the deep interval.

The boundary, or depth of the transition, between the intermediate and deep groundwater intervals varies throughout the ORR (Table 3.1). In Bear Creek Valley, the boundary interval is based in part on lower hydraulic conductivity, but where that is obscure, unusually high head estimates (apparently erroneous extrapolation from packer tests) are used to delineate the deep interval. Hydraulic conductivity is an unreliable indicator because fracture zones can create permeable intervals within an overall low-permeability interval. In contrast to Melion and Bethel valleys, the transition from the intermediate to the deep zone in Bear Creek Valley consistently occurs at greater depths, between $1(0)$ and $200 \mathrm{~m}$. 
Table 3.1 Summary of measured hydraulic conductivity values for the intermediate and deep interval, Bear Creek, Bethel, and Melton Valleys.

\section{CONASAUGA AQUTTARD, EAST BEAR CRLEK VAL.LEY (3 WEILS)} STRADDIEPACKER TESTS

\begin{tabular}{|c|c|c|}
\hline BOUNDARY $(90-215 \mathrm{~m})$ & Intermediate & Deep \\
\hline GEOMETRIC MEAN & $2.1 \times 10^{-6} \mathrm{~cm} / \mathrm{s}$ & $3.1 \times 10^{-7} \mathrm{~cm} / \mathrm{s}$ \\
\hline STAND DEV (log units) & 2.9 & 1.0 \\
\hline NUMBER & 13 & 8 \\
\hline \multicolumn{3}{|c|}{$\begin{array}{l}\text { CONASAUGA AQUTTARD, WEST BEAR CRLEK VALLEY (8 WEI LS) } \\
\text { STRADDLEPACKER TESTS }\end{array}$} \\
\hline BOUNDARY $(90-180 \mathrm{~m})$ & Intermediate & Decp \\
\hline GEOMETRIC MEAN & $5.8 \times 10^{-6} \mathrm{~cm} / \mathrm{s}$ & $4.5 \times 10^{-7} \mathrm{~cm} / \mathrm{s}$ \\
\hline STAND DEV (log units) & 1.0 & 0.8 \\
\hline NUMBER & 54 & 34 \\
\hline \multicolumn{3}{|c|}{$\begin{array}{l}\text { CONASAUGA AQUTTARD, MELTON VALLEY (11 WELLIS) } \\
\text { SLOW RESPONSE ANALYYSIS AND SLUG TESTS }\end{array}$} \\
\hline BOUNDARY $(60-90 \mathrm{~m})$ & Intermediate & Deep \\
\hline GIOMETRIC MIFAN & $3.9 \times 10^{-6} \mathrm{~cm} / \mathrm{s}$ & $4.6 \times 10^{-9} \mathrm{~cm} / \mathrm{s}$ \\
\hline STAND DEV (log units) & 1.1 & 0.3 \\
\hline NUMBER & 19 & 7 \\
\hline \multicolumn{3}{|c|}{$\begin{array}{l}\text { CONASAUGA AQUITARD, MEI.TON VALLLEY (I WIILL) } \\
\text { STRADDLEPACKER TESTS }\end{array}$} \\
\hline BOUNDARY $(150 \mathrm{~m})$ & Intermediate & Deep \\
\hline GEOMETRIC MEAN & $2.8 \times 10^{-6} \mathrm{~cm} / \mathrm{s}$ & $1.8 \times 10^{-8} \mathrm{~cm} / \mathrm{s}$ \\
\hline STAND DEV (log units) & 1.1 & 0.3 \\
\hline NUMBERR & 9 & 5 \\
\hline \multicolumn{3}{|c|}{$\begin{array}{c}\text { CHICKAMAUGA AQUITARD, BETHEL. VALLIEY' (5 WEI.LS) } \\
\text { STRADDLEPACKER TTESTS }\end{array}$} \\
\hline BOUNDARY $(50 \mathrm{~m})$ & Intermediate & Deep \\
\hline GEOMETRIC MEAN & $1.8 \times 10^{-5} \mathrm{~cm} / \mathrm{s}$ & $1.7 \times 10^{-7} \mathrm{~cm} / \mathrm{s}$ \\
\hline STAND DF:V (log units) & 0.7 & 1.0 \\
\hline NUMIBIRR & 8 & 29 \\
\hline
\end{tabular}


In Melton Valley, the transition zone occurs at depths as shallow as $45-60 \mathrm{~m}$, based on single-well tests, water level response to precipitation events, and electrical conductance data (Dreier and Toran 1989). However, the transition appears to occur at a deeper level below major streams-between 60 and $120 \mathrm{~m}$; that is, the intermediate groundwater interval is thicker below Whiteoak Creek and Whiteoak Lake (Dreier and Toran 1989). Based on limited straddle packer data from one borehole (WOL-2), the transition zone may be as deep as $150 \mathrm{~m}$ near Whiteoak Dam. In Bethel Valley the transition zone occurs at $\sim 45 \mathrm{~m}$, based on straddle packer data .

Measurements of hydraulic gradients in the deep groundwater intervals are sparse, but they have been estimated from Hydrostatic Head Monitoring Station (HHMS) wells in Melton Valley and from multiport monitoring wells in Bear Creek Valley. The 65-m-deep HHMS wells show a horizontal gradient of $\sim 0.005$, and a similar gradient is seen among a more limited number (3) of 130-m-deep wells. Vertical gradients in the HHMS clusters were on the order of 0.03 , except for the northernmost cluster, HHMS-9, which had a gradient of 0.2 between the 25 - and 80 -m-deep wells. In the Bear Creek Valley multiport monitoring wells, steep gradients were observed. Horizontal gradients were on the order of 0.1 and vertical gradients varied between 0.3 and 0.01 . Thus, the observed gradients are higher in Bear Creek Valley than in Melton Valley. Two factors may explain this observation. First, there are more data from Bear Creek Valley, which may lead to extreme values. In particular, there are only limited data from the ridges above Melton Valley. Second, the beds dip more steeply in Bear Creek Valley, so when flow occurs from the ridge top to valley bottom, it is nearly perpendicular to bedding. This direction is believed to be a low permeability direction, and steeper gradients would be required to transmit similar quantities of water. Neither of these explanations has been quantified yet.

Few data are available for the porosity of rocks in the deep interval. Ten measurements on cores from the Joy-1 borehole showed a geometric mean porosity of $8.4 \times 10^{-3}$ and a range of $3.9 \times 10^{-3}-1.9 \times 10^{-2}$ for the Conasauga Group and the Chickamauga Group at depths of 47-870 m (de Laguna et al. 1968). These results represent the total porosity of fresh rock, including any microfractures. The relationship of porosity and depth is uncertain in these data.

Several tracer tests have been conducted in the groundwater zone, and the results provide substantial insight into water movement as well as contaminant transport processes. In general, two distinct migration rates have been observed: (1) the velocity of the leading 
edge of the tracer plume (i.e., the velocity given by the first arrival of a tracer) and (2) the velocity of peak concentration. First arrival velocities of $1-2 \mathrm{~m} / \mathrm{d}$ have been observed in tests conducted in the groundwater zone of the ORR aquitards (Davis et al. 1984; Webster and Bradley 1983). However, the velocity given by the time required to reach peak concentration (when a sluglike injection of tracer has occurred) is $0.055-0.17 \mathrm{~m} / \mathrm{d}$. The large difference between first arrival and peak concentration implies that longitudinal dispersion is a strong process. Because the tracer tests have been conducted over small distances $(<10 \mathrm{~m})$, apparent longitudinal dispersion, as indicated by the difference between peak velocity and first arrival velocity, after longer travel times is likely to be even greater than suggested by the tracer tests.

The observed longitudinal spreading can be explained by sorption and matrix diffusion. As shown by Giliham and Cherry (1982), diffusive exchange between highly permeable and less permeable regions can produce solute plumes that are extremely elongated in the direction of flow. The first-arrival velocity results from rapid migration along fracture pathways; however, sorption and diffusion into the porous matrix substantially retard the majority of solute mass. Thus, bulk solute mcvement (i.e., peak concentrations) migrate at a much slower rate than fluid velocities in permeable regions.

The concept of a groundwater zone that is most active near the water table and becomes increasingly sluggish with depth is supported by geochemical dating studies. Poreda et al. (1988) utilized ${ }^{3} \mathrm{H}$ (12.4-year half-life) and its stable daughter ${ }^{3} \mathrm{He}$ to date groundwater collected from SWSA 6, which is located in the area of the ORR aquitards. The use of both parent and daughter isotopes precluded the need to accurately determine the ${ }^{3} \mathrm{H}$ activity in waste sources. Sample depth ranged from 0.78 to $2.67 \mathrm{~m}$ below the water table, and calculated ages ranged from 0.09 to 7.23 years. In August of 1988 additional samples were collected from deeper monitoring wells at depths ranging from 14 to $50 \mathrm{~m}$ below the water table. Large amounts of radiogenic ${ }^{4} \mathrm{He}$ were measured; this suggests residence times that are much greater than those near the water table; however, precise ages using the ${ }^{3} \mathrm{H} /{ }^{\beta} \mathrm{He}$ method could not be determined because the ${ }^{3} \mathrm{He} /{ }^{4} \mathrm{He}$ ratio of radiogenic $\mathrm{He}$ in the area of the aquitards has not been determined.

Carbon isotopes and ${ }^{3} \mathrm{H}$ have been measured in groundwater at depths ranging from 60 to $100 \mathrm{~m}$ below land surface in Melton Valley (Toran et al. 1991). The ${ }^{13} \mathrm{C}$-corrected ${ }^{14} \mathrm{C}$ ages range from 3,000 to 30,000 years; however, ${ }^{3} \mathrm{H}$ (which could not have infiltrated $>50$ years ago) was also detected. 'Transport through fractures may account for the 
presence of small quantities of ${ }^{3} \mathrm{H}$ with the long residence times suggested by the ${ }^{14} \mathrm{C}$ results. Results from a model of flow in parallel fractures with diffusion into the rock matrix suggest that the observed ${ }^{14} \mathrm{C}$ and ${ }^{3} \mathrm{H}$ data can be explained using values for parameters such as fracture spacings that are consistent with independent measurements (e.g., the borehole flow meter results). In addition, the modeling has placed bounds on effective fracture apertures ( 30 to $50 \mu \mathrm{m}$ ) that have not been independently measured.

However, an additional parameter needed is retardation of ${ }^{14} \mathrm{C}(\mathrm{R}=8)$ which would reduce the range of the measured age of the water to 800-4000 years. One way of viewing the very slow solute migration rates suggested by the ${ }^{14} \mathrm{C}$ results $(\sim 25-40 \mathrm{~cm} / \mathrm{year})$ with the very fast rates indicated by the presence of ${ }^{3} \mathrm{H}(\sim 150 \mathrm{~m} / \mathrm{year})$ is as follows. If an instantaneous release of a geochemically conservative contaminant occurred, the leading edge of the plume would be expected to migrate at $\sim 150 \mathrm{~m} /$ year (as given by the ${ }^{3} \mathrm{H}$ data); however, peak contaminant concentrations (i.e., the center of mass of the contaminant plume) would migrate at a rate of $25-40 \mathrm{~cm} /$ year (as given by the ${ }^{14} \mathrm{C}$ data).

The extreme difference between the first-arrival velocity and the migration rate of peak concentrations that results from matrix diffusion has important implications for waste management and environmental restoration. Because the first-arrival velocity is large, the detection of a large new contaminant source (e.g., the sudden rupture of a buried drum) can occur quickly, provided that fracture pathways are adequately monitored. However, because most of the contaminant mass will migrate at a relatively slow rate, remedial actions (if necessary) can be planned and can occur in an orderly fashion. In other words, catastrophic releases will be buffered by diffusion into less permeable regions but could be detected quickly before substantial migration occurs. The lag time between first detection (which is strongly related to the efficiency of a monitoring system) and peak concentration is not known precisely, and additional investigation is needed. 


\subsubsection{Characteristics of the Aquiclude}

Saline water underlies the deep flow interval on the ORR. Total dissolved solids content ranges from $\sim 40,000$ to $300,000 \mathrm{mg} / \mathrm{L}$ (Haase, Switek, and Stow 1987; Switek, Haase, and Stow 1987). Compositionally, it is a $\mathrm{Na}^{+}, \mathrm{Ca}^{+}$, and $\mathrm{Cl}^{-}$-rich brine that chemically resembles brines associated with major sedimentary basins, such as the Illinois Basin or the Gulf Coast of the United States. In Melton Valley the saline water is first encountered at depths ranging from 180 to $240 \mathrm{~m}$ (Haase, Switek, and Stow 1987; Switek, Haase, and Stow 1987). Water from depths between $\sim 120$ and $180 \mathrm{~m}$ typically contains brackish water having total dissolved solids of several thousand to several tens of thousand $\mathrm{mg} / \mathrm{L}$ (Switek, Haase, and Stow 1987; Dreier and Toran 1989). Such values are far greater than those characteristic of regions of active groundwater flow but significantly smaller than those of the saline water. This suggests that there may be either a mixing zone or a diffusion zone between fresh and saline water at the base of the active groundwater flow system. In the Conasauga of Bear Creek Valley, saline water has not been encountered in wells penetrating to depths of $300 \mathrm{~m}$. Wells completed in the depth range of 150 to $300 \mathrm{~m}$, however, do encounter groundwater with total dissolved solids contents in the several thousand $\mathrm{mg} / \mathrm{L}$ range. This observation suggests that saline water also is present undemeath Bear Creek Valley but at greater depths than in Melton Valley. Information on the occurrence of saline water elsewhere in the ORR is sparse, although 240-m-deep core holes in Bethel Valley appear to intersect groundwaters with elevated total dissolved solids contents at depths below $180 \mathrm{~m}$ (Haase, Gillis, and King 1987; Haase, King, and Gillis 1987). The origin of the saline water is unknown. Possibilities include chemically evolved formation waters that have undergone extensive water/rock interaction and formation waters that have dissolved evaporite deposits. Similarly, the age and flow dynamics of the saline water have not been determined.

\subsection{CHEMICAL CHARACTERISTICS}

The chemical characteristics of uncontaminated groundwater on the ORR provide insight into many subsurface flow and transport processes that are important for the migration of contaminants. Because transport rates on the ORR are generally small, the use of natural geochemical surrogates allows an interpretation of large-scale transport rates at time scales that cannot be evaluated by using short-term tracer tests or by monitoring contaminant plumes. 


\subsubsection{Chemical Characteristics of Water in the Stormflow Zone}

All water samples collected from the stormflow monitoring tubes (Sect. 3.1.1) in the headwaters area of Melton Branch were cloudy to muddy, and a large majority of the suspended sediment was colloidal in size. The concentration of suspended sediment was not measured and probably was small. Nevertheless, the discharge of colloidal material from the stormflow zone may explain some of the turbidity in high base streamflows. Also, some pollutants could be sorbed by these colloids in contaminated areas and thereby transported to the streams. Water samples from the stormflow zone in the Walker Branch watershed of the Knox aquifer contained little colloidal material, but $>55 \%$ of iron and aluminum was transported as suspended particles (Wilson et al. 1991).

Water in the stormflow zone of Melton Valley is slightly acidic. The arithmetic mean of $\mathrm{pH}$ for 150 measurements is 5.8 , and the range from the mean minus one to the mean plus one standard deviation is 5.2-6.5. The water is a calcium bicarbonate type and has smaller concentrations of magnesium, sodium, and (probably) sulfate. Data for $\sim 200$ water samples from stormflow monitoring tubes in the Melton Branch headwaters area show that the concentrations of chemical constituents are lognormally distributed. The geometric mean of total hardness, as $\mathrm{CaCO}_{3}$, is $41 \mathrm{mg} / \mathrm{L}$; the geometric mean of total alkalinity, as $\mathrm{CaCO}_{3}$, is $48 \mathrm{mg} / \mathrm{L}$; and the geometric mean of specific conductance is $109 \mu \mathrm{mhos} / \mathrm{cm}$ at $25^{\circ} \mathrm{C}$. For 80 water samples, the geometric mean of calcium concentrations is $12 \mathrm{mg} / \mathrm{L}$, the geometric mean content of magnesium is $2.4 \mathrm{mg} / \mathrm{L}$, and the geometric mean of sodium content is $1.5 \mathrm{mg} / \mathrm{L}$. Different analyses were made on water samples from the stormflow zone in the Walker Branch watershed (Wilson et al. 1991). Calcium content in 12 samples had a range of 1.3-3.9 mg/L, and generally, $\mathrm{Ca}>\mathrm{Mg}>\mathrm{K}>\mathrm{Na}>\mathrm{Al}>\mathrm{Fe}>\mathrm{Mn}$. Both sulfur and silicon contents were typically larger than the calcium content, but concentrations of all constituents were $<5 \mathrm{mg} / \mathrm{L}$ in the samples.

The concentrations of chemical constituents in waters from the stormflow zone are variable in space and time, and there is no detectable correlation with topographic elevation, landform type, or characteristics of the tube responses to rainfall events. For example, the specific conductance of water samples from tube A (locations on Fig. 3.3), near a drainage divide, had a range of $68-281 \mu \mathrm{mhos} / \mathrm{cm}$ in 8 samples, and 14 samples of water from tube $\mathrm{K}$, somewhat farther downslope, had a range of $93-443 \mu \mathrm{mhos} / \mathrm{cm}$. Near the base of a hillslope, 21 samples of water from tube $H$ had a range of $32-81 \mu \mathrm{mhos} / \mathrm{cm}$, and 17 samples of water from tube $J$, near a stream, had a range in specific conductance of 
$100-555 \mu \mathrm{mhos} / \mathrm{cm}$. Some increases in chemical concentration may occur between rainfall events because of water consumption by evapotranspiration, but changes of this type, if they occur, are not apparent in the data. The highest measurements of specific conductance are nearly the same as those from some wells in the groundwater zone, and a connection of the stormflow and groundwater zones may occur on some hillslopes. However, the spatial and temporal differences in the chemical contents of stormflow waters are presently not adequately understood.

\subsubsection{Chemical Characteristics of Water in the Groundwater Zone}

A brief summary of chemical constituents in the groundwater zone to depths of $<165 \mathrm{~m}$ is provided in Table 3.2. These data represent filtered samples, but have not been screened for errors in ion balances or extreme $\mathrm{pH}$ values. Duplicate analyses of water from the same well are included in the statistical summary. Despite these limitations, the data set is large enough that the median values are believed to be close to representative of values for uncontaminated waters, based on more selective analysis of calcium and bicarbonate data from the table.

Chemical constituents and specific conductances of groundwater on the ORR are lognormally distributed. All data for each parameter constitute a single population except in contaminated areas (Table 3.2). The ranges of the concentrations thus result from processes that occur along the groundwater flow paths-solution, clay alteration, ion exchange, mixing, sorption, colloid transport, matrix diffusion, and dispersion. The concentration of major ions ( $\mathrm{Ca}, \mathrm{Mg}, \mathrm{Na}$, alkalinity, $\mathrm{Cl}$, and $\mathrm{SO}_{4}$ ) is variable, and the range between the mean minus one to mean plus one standard deviation is generally greater than a factor of 10 . In $90 \%$ of the samples Ca contents range from 3 to $1700 \mathrm{mg} / \mathrm{L}$, alkalinity from 47 to $560 \mathrm{mg} / \mathrm{L}$, and $\mathrm{Cl}$ from 0.07 to $170 \mathrm{mg} / \mathrm{L}$. Magnesium and sodium contents are commonly smaller than calcium and are in approximately equal concentrations. The water is slightly acidic to moderately alkaline.

Potassium, nitrate (as nitrogen), and sulfate generally occur at concentrations of 1-15 mg/L. However, sulfate contents of $30-1000 \mathrm{mg} / \mathrm{L}$ occur in a few wells in the Conasauga Group and are apparently caused by the solution of gypsum. Most fluoride contents are $<1.0 \mathrm{mg} / \mathrm{L}$, but a few of the deeper wells in limestone units have fluoride contents of $2.6 \mathrm{mg} / \mathrm{L}$. Iron and manganese contents rarely exceed secondary drinking water standards $(0.3$ and $0.05 \mathrm{mg} / \mathrm{L})$ in filtered water samples, but most unfiltered samples exceed these standards. 


\section{Table 3.2 Chemical constituents and physical properties of groundwater from wells $<165 \mathrm{~m}$ deep near ORNL and the Y-12 Plant.}

\begin{tabular}{|c|c|c|c|c|c|c|c|c|}
\hline $\begin{array}{l}\text { Constituent } \\
\text { or property }\end{array}$ & $\begin{array}{l}\text { No. of } \\
\text { values }\end{array}$ & Minimum & 5 percentile & $\begin{array}{c}\text { Mean - } 1 \\
\text { std deviation } \\
\end{array}$ & $\begin{array}{c}\text { Geometric } \\
\text { mean }\end{array}$ & $\begin{array}{c}\text { Mean +1 } \\
\text { std deviation } \\
\end{array}$ & $\begin{array}{l}95 \text { Per- } \\
\text { centile }\end{array}$ & Maximum \\
\hline Total aik. & 2091 & $<2$ & $47^{a}$ & 72 & 160 & $380^{a}$ & 560 & 610 \\
\hline Antimony & 2624 & $<0.002$ & $0.030^{a}$ & $0.045^{a}$ & $0.085^{a}$ & $<0.003$ & $0.25^{a}$ & 0.27 \\
\hline Arsenic & 3084 & $<0.001$ & $<0.003$ & $<0.003$ & $<0.003$ & 0.55 & $0.0030^{a}$ & 0.24 \\
\hline Barium & 2959 & 0.0002 & 0.005 & 0.016 & 0.095 & 0.23 & 1.7 & 290 \\
\hline Boron & 2775 & $<0.0001$ & 0.0034 & 0.01 & 0.048 & & 0.64 & 31 \\
\hline Cadmium & 2734 & 0 & $<0.001$ & $<0.001$ & $<0.001$ & 0.0015 & 0.018 & 5.7 \\
\hline Calcium & 2180 & 0.45 & 3.2 & 13 & 81 & 520 & 1700 & 2200 \\
\hline Chloride & 2612 & 0 & $0.067^{a}$ & 0.3 & 3.3 & 36 & 170 & 3300 \\
\hline Chrornium & 2758 & 0 & $<0.001$ & $<0.001$ & $<0.002$ & 0.016 & 0.056 & 6.4 \\
\hline Copper & 2773 & $<0.0001$ & $<0.001$ & $<0.001$ & 0.0024 & 0.041 & 0.25 & 180 \\
\hline Fluoride & 2100 & () & $0.0064^{a}$ & $0.019^{a}$ & 0.12 & 0.67 & 2.1 & 36 \\
\hline Iron & 1550 & 0 & $<0.004$ & $<0.004$ & 0.004 & 0.069 & 0.42 & 22 \\
\hline Lead & 4611 & $<0.001$ & $<0.001$ & $<0.001$ & 0.0022 & 0.016 & 0.053 & 3.4 \\
\hline Magnesium & 2094 & $<0.001$ & 0.9 & 2.7 & 15 & 78 & 240 & 1900 \\
\hline Manganese & 1443 & $<0.001$ & $<0.001$ & $<0.001$ & 0.027 & 1 & 9.7 & $350^{d}$ \\
\hline Mercury & 4071 & $<0.0001$ & $<0.0001$ & $<0.0002$ & $<0.0002$ & $<0.0002$ & 0.00058 & 0.99 \\
\hline Nitrogen & 2401 & $<0.1$ & $0.017^{a}$ & $0.055^{a}$ & 0.51 & 3.9 & $15^{e}$ & $50,000^{e, f}$ \\
\hline $\mathrm{pHI}$ & 2734 & $2.9^{c}$ & 5.2 & 6.2 & 7.7 & 9.2 & $10.2 f$ & $13.1 f$ \\
\hline Potassium & 2052 & $<0.6$ & $0.51^{a}$ & 1 & 3.2 & 8.5 & 17 & 5308 \\
\hline Selenium & 3637 & $<0.001$ & $<0.001$ & $<0.001$ & $<0.001$ & $<0.001$ & 0.001 & 0.098 \\
\hline Silver & 2732 & $<0.0001$ & $<0.002$ & $<0.002$ & $<0.002$ & $0.0026^{a}$ & 0.018 & 0.54 \\
\hline Sodium & 2304 & 0.21 & 0.55 & 1.8 & 12 & 74 & 230 & 1800 \\
\hline Sp. Cond. & 2674 & 10 & 70 & 160 & 800 & 3640 & 9410 & $67.400^{h}$ \\
\hline Sulfate & 2588 & $<1$ & $1.5^{a}$ & 3.6 & 14 & 52 & 124 & 1000 \\
\hline Zinc & 2794 & $<0.001$ & $<0.001$ & 0.0016 & 0.011 & 0.073 & 0.25 & 27 \\
\hline
\end{tabular}

Note: Concentrations in $\mathrm{mg} / \mathrm{L}$, except as noted; alkalinity as $\mathrm{CaCO}_{3} ;$ specific conductance in $\mu$ mhos $/ \mathrm{cm}$.at $25^{\circ} \mathrm{C}$. Fillered samples.

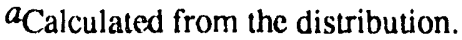

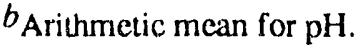

${ }^{c}$ Contamination by acid may be indicated by $\mathrm{pH}<4.0$.

${ }^{d}$ Exceeds solubility limit, sample probably not filtered.

$e_{\text {Concentrations }}>10 \mathrm{mg} / \mathrm{L}$ may indicate contamination.

$f_{\text {Contamination by grout cement may be indicated }}$ by $\mathrm{pH}>10$.

$g$ Concentrations $>25 \mathrm{mg} / \mathrm{L}$ may indicate contamination.

$h_{\text {Values }}>10,000 \mu \mathrm{mhos} / \mathrm{cm}$ may indicate contamination. 
Relatively large concentrations of other metals are common in groundwater from shale units, especially in unfiltered samples, and are not necessarily evidence of contamination.

Significant variations in the chemical characteristics of groundwater with depth have been observed in both Melton Valley and Bear Creek Valley (Fig. 3.11). At depths $<20-50 \mathrm{~m}$ in the aquitards, $\mathrm{Ca}$ is the dominant cation and $\mathrm{HCO}_{3}$ is the dominant anion (Bailey and Lee 1989; Webster and Bradley 1988; Dreier and Toran 1989). At depths $>20-50 \mathrm{~m}, \mathrm{Na}$ becomes the dominant cation, and $\mathrm{HCO}_{3}$ is the dominant cation. A sodium bicarbonate water type occurs in a few wells deeper than $30 \mathrm{~m}$ in the aquitards of the Chickamauga group in Bethel Valley (Stockdale 1951), but clear trends in the chemical characteristics have not been determined.

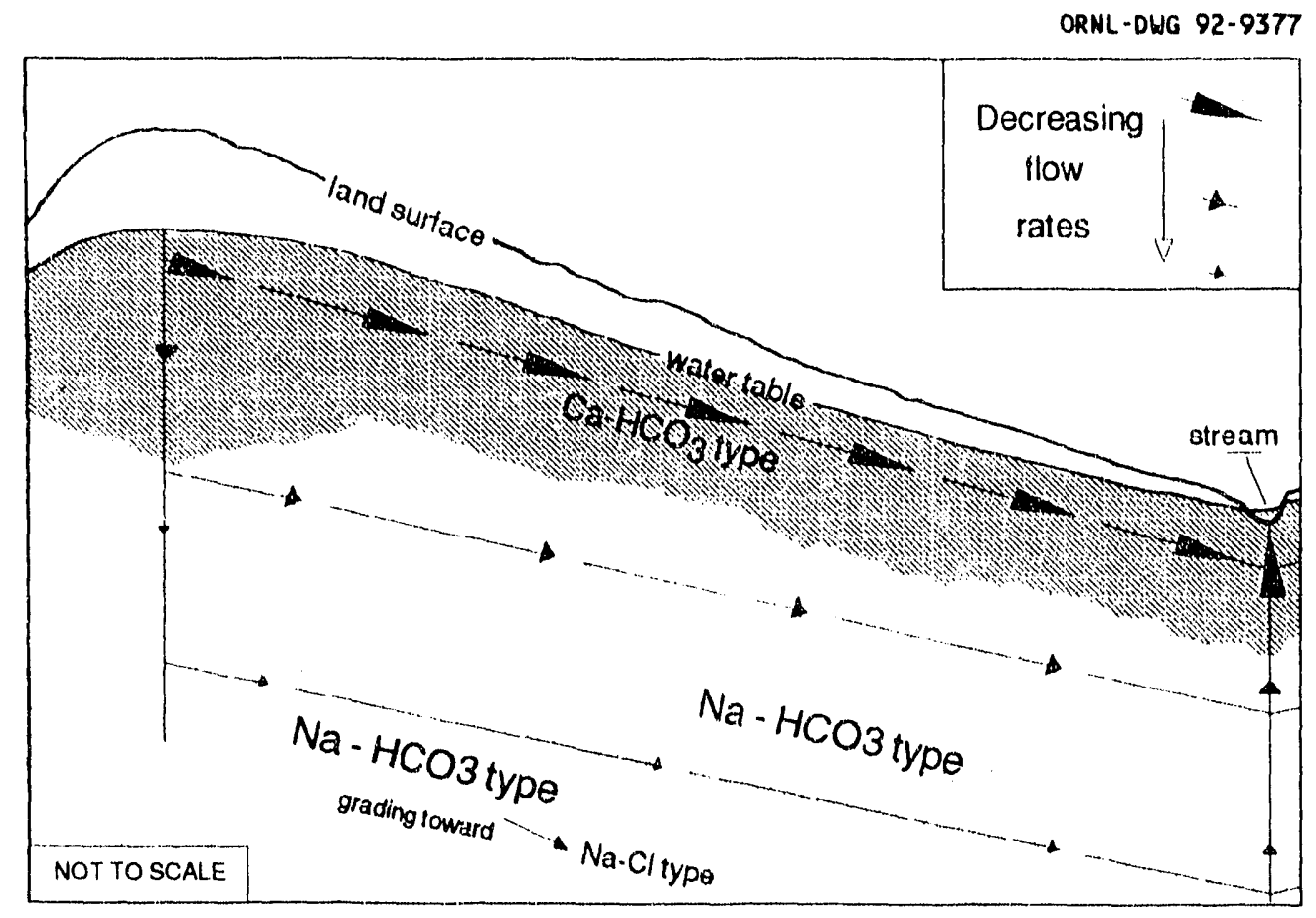

Fig. 3.11. Schematic cross-section showing very generalized How paths, related geochemical evolution, and relative flow rates.

Typically, the evolution from $\mathrm{Ca}-\mathrm{HCO}_{3}$ to $\mathrm{Na}-\mathrm{HCO}_{3}$ to $\mathrm{Na}-\mathrm{Cl}$ type water is attributed to the exchange of $\mathrm{Na}$ for $\mathrm{Ca}$ on exchange sites of clays. Recent geochemical modeling indicates that $\mathrm{Na}-\mathrm{HCO}_{3}$ waters can also be produced by clay alteration. For example, potassium illite and $\mathrm{Na}$-feldspar can weather to an aluminosilicate such as calcium smectite, 
releasing $\mathrm{Na}$ and $\mathrm{Si}$, precipitating $\mathrm{CaCO}_{3}$, and increasing $\mathrm{pH}$. This process should decrease the $\mathrm{Ca} / \mathrm{Mg}$ ratio.

The cation exchange mechanism and the clay alteration mechanism imply different things about the evolution and length of the groundwater flow system. In the case of cation exchange, three stages occur. First, $\mathrm{Ca}-\mathrm{HCO}_{3}$ water is present; second, sufficient exchange occurs that $\mathrm{Na}$ is the dominant cation; and third, exchange sites fill up so that Ca-type water will flush out $\mathrm{Na}$-type water. Thus, the $\mathrm{Na}-\mathrm{HCO}_{3}$ boundary eventually gets pushed down and out. Groundwater compositions alone cannot indicate which state is operating, so the presence of $\mathrm{Na}-\mathrm{HCO}_{3}$-type water is only an ambiguous indicator of evolved water.

For clay alteration, the rate at which the system reaches chemical equilibrium and the quantity of source minerals are the only factors in evolution of $\mathrm{Na}-\mathrm{HCO}_{3}$ waters. Although these are difficult to determine precisely, the presence of $\mathrm{Na}-\mathrm{HCO}_{3}$ type waters from clay alteration indicates water in its final equilibrium stage unless there is a change in the flow system directions. Under the clay alteration scenario, shallow groundwater that discharges into streams may not evolve to the $\mathrm{Na}-\mathrm{HCO}_{3}$ endpoint because of short flow paths (i. e., the water-to-rock ratio is too small). Thus, if clay alteration is an important mechanism, the $\mathrm{Na}-\mathrm{HCO}_{3}$ type water may mark the transition between active circulation and sluggish groundwater flow. Additional geochemical studies are needed in order to interpret unambiguously the hydrologic significance of the change from $\mathrm{Ca}-\mathrm{HCO}_{3}$ to $\mathrm{Na}-\mathrm{HCO}_{3}$ type water.

Although the hydrogeochemical processes that result in a change from $\mathrm{Ca}-\mathrm{HCO}_{3}$ to $\mathrm{Na}-\mathrm{HCO}_{3}$ to $\mathrm{Na}-\mathrm{Cl}$ type water are not entirely quantified and characterization of water types is sometimes complicated by well-purging difficulties and perhaps by the presence of dissolved grout constituents (Dreier and Toran 1989), these transitions probably are related to long residence times and decreases in water flux with depth. The approximate relationship among depth, groundwater interval, and water type for the ORR aquitards is shown in Table 3.3 . 


\section{Table 3.3 Approximate relationship among depth, flow interval, and water type for the ORR aquitards}

\begin{tabular}{ccc}
\hline $\begin{array}{c}\text { Depth below permanemt water } \\
\text { table to bottom of flow } \\
\text { interval }(\mathrm{m})\end{array}$ & $\begin{array}{c}\text { Interval } \\
\text { or } \\
\text { zone }\end{array}$ & Water type \\
\hline 1 to 3 & Water table & $\mathrm{Ca}-\mathrm{HCO}_{3}$ \\
20 to 50 & Intermediate & $\mathrm{Na}-\mathrm{HCO}_{3}$ \\
150 to 400 & Deep & $\mathrm{Na}-\mathrm{HCO}_{3}$ to $\mathrm{Na}-\mathrm{Cl}$ \\
$\mathrm{NA}$ & Aquiclude & $\mathrm{Na}-\mathrm{Cl}$ \\
\hline
\end{tabular}

In the Knox aquifer, a Ca-Mg- $\mathrm{HCO}_{3}$ type water exists to depths of nearly $300 \mathrm{~m}$ (Dreier et al. 1991), and a transition to $\mathrm{Na}-\mathrm{HCO}_{3}$ or $\mathrm{Na}-\mathrm{Cl}$ has not been observed. Differences in the major ion chemistry of groundwater in the Knox aquifer compared with that of the ORR aquitards results from differences in residence times as well as dominant geochemical reactions. Ion exchange, for example, may be an important mechanism controlling the transition from $\mathrm{Ca}$ - to $\mathrm{Na}-\mathrm{HCO}_{3}$ type water in the ORR aquitards but may have little influence on the major ion chemistry of the Knox aquifer.

The depth of transition to $\mathrm{Na}-\mathrm{Cl}$ type water also varies across the ORR. At depths $>130$ $200 \mathrm{~m}$, the dominant anion changes from $\mathrm{HCO}_{3}$ to $\mathrm{Cl}$ (Dreier and Toran 1989; Bailey and Lee 1989). At depths $>30-50 \mathrm{~m}$, $\mathrm{Na}$ becomes the dominant cation and $\mathrm{HCO}_{3}$ remains the dominant anion. A brine with dissolved solids contents of $50,000-300,000 \mathrm{mg} / \mathrm{L}$ occurs below depths of $180 \mathrm{~m}$ in Melton Valley and probably occurs at somewhat deeper levels elsewhere on the ORR. The chemical constituents of these waters represent different statistical populations, and the concentrations have not been included in Table 3.2. These waters are acidic and represent a sodium chloride type that contains lesser amounts of calcium and magnesium, minor amounts of strontium and bromide, and trace amounts of potassium, barium, lithium, manganese, and iron (Switek et al. 1987; Haase et al. 1987). These characteristics are those of membrane-concentrated water and connate brine. Water samples from three wells 145-162 m deep in Bear Creek Valley showed an alkaline sodium chlotide--bicarbonate water type with a pH in the range 8.5-10.0. These waters probably represent a transition from a sodium bicarbonate type to a sodium chloride type and occur near the base of any significant groundwater circulation. A well $400 \mathrm{~m}$ deep in the Knox aquifer in Bear Creek Valley did not encounter Na-Cl type water (Dreier et al. 1991), but core below the bottom sampling interval contains celestite, a $\mathrm{SrSO}_{4}$ mineral typical of briney water. 
Stable isotopes of water, $18 \mathrm{O}$ and $\mathrm{D}$ (deuterium), have been measured for 17 shallow and deep groundwater samples in Melton Valley (Fig. 3.12). In addition, water samples from five rainfall events were collected. These data can provide information on recharge and groundwater flow paths because the isotopes can provide a fingerprint for water from flow systems that have undergone different processes. The samples from depths of $30-60 \mathrm{~m}$ in HHMS wells and USGS wells fall on the typical meteoric water line, representing local area recharge. Deeper samples (from 130-m-deep HHMS wells) have a heavier $18 \mathrm{O}$ signature, indicating older recharge or water/rock interactions. The three deep samples fall on a line that intersects the meteoric water line at the value of the shallower samples, which may be indicative of mixing between older and younger waters.

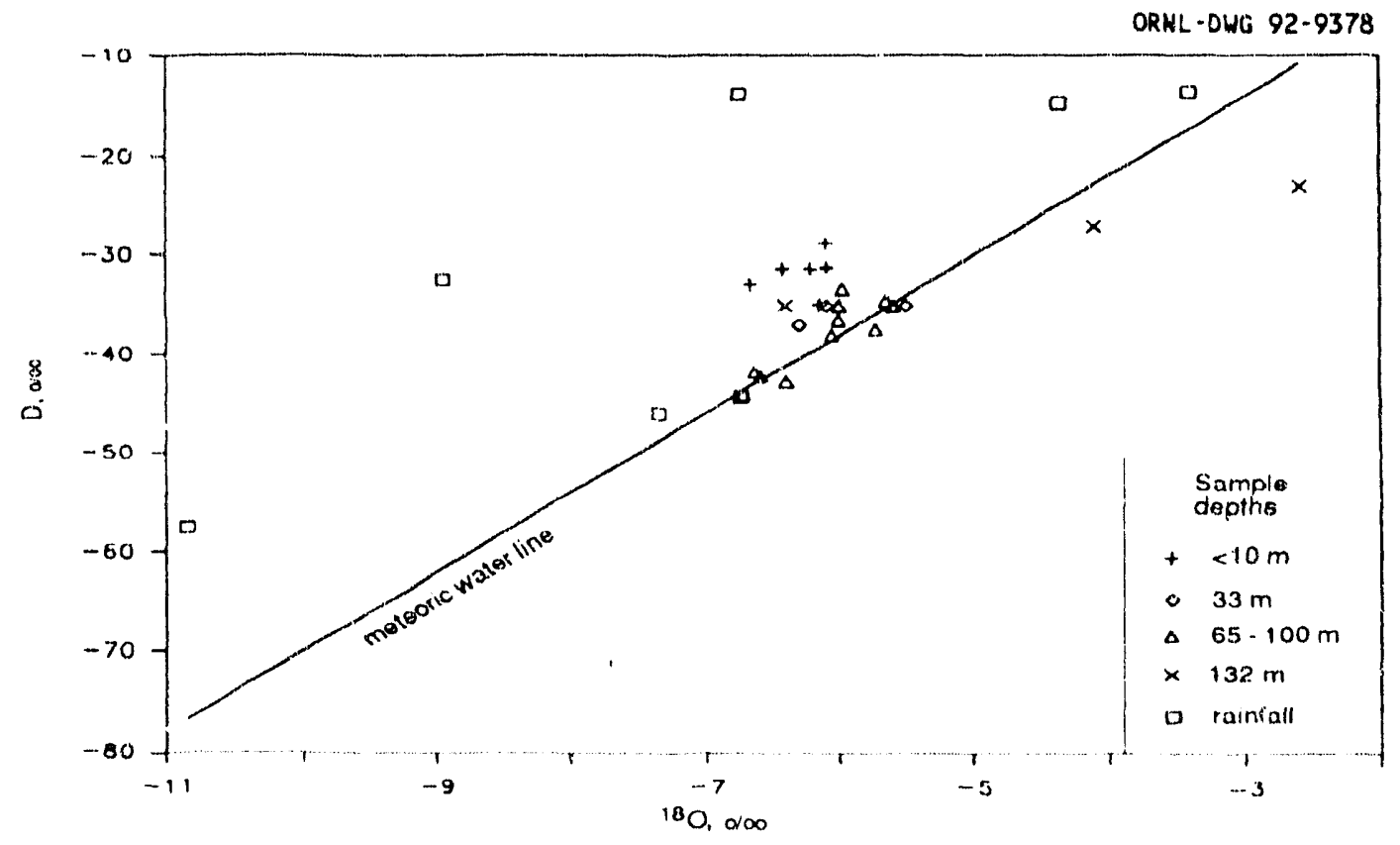

Fig. 3.12 Deuterium vs 180 for groundwater a $1 \mathrm{~d}$ rainwater samples collected on the ORR and their relationship to the meteoric water line.

The data from rainfall collected from a site in Bethel Valley show greater variability in both $18 \mathrm{O}$ and $\mathrm{D}$ than groundwater samples, as expected. The isotopic composition of rainfall is a function of temperature and source, which can vary during storms. By the time the stormflow reaches the groundwater, the isotope signature has been integrated to a value characterized by the meteoric water line describing the relationship between $\mathrm{D}$ and $18_{\mathrm{O}}$.

The data from shallow depths $(<10 \mathrm{~m})$ in SWSA 4 also have a distinct isotope signature. The ${ }^{18} \mathrm{O}$ values are similar to the data that fell on the meteoric water line, but the $D$ values 
are heavier than expected. Two different hypotheses are suggested to explain the data. The heavier $\mathrm{D}$ may be caused by some waste-related activity. If so, $\mathrm{D}$ would be an additional conservative tracer of contaminant movement. The second hypothesis is that integration of the rainfall did not occur in this shallow groundwater zone because of the presence of highly fractured and heterogenous rock. To test this hypothesis, shallow samples need to be collected away from the waste areas. Additional $\mathrm{D}$ and $18 \mathrm{O}$ data from deep and shallow zones and from rainfall should help in elucidating groundwater flow paths on the ORR.

\subsubsection{Sorption Properties of Soil and Rock}

The mobility of most contaminants on the ORR is greatly reduced by sorption onto solids in the subsurface. The sorption coefficient (Kd) describes the proportion of solute sorbed to surfaces assuming reversible equilibrium with the surrounding solution; it translates to a retardation factor $(R)$ in the solute transport equation. The retardation factor for a granular porous media is related to $\mathrm{Kd}$ by

$$
R=1+\frac{\rho_{b}}{\theta}(K d)
$$

where

$$
\begin{aligned}
& R=\text { retardation factor, } \\
& \rho_{b}=\text { bulk density, } \\
& \theta=\text { total porosity. }
\end{aligned}
$$

For the stormflow and vadose zones of the aquitards, the ratio of $\rho_{b} / \theta$ is $\sim 5-10$. In the groundwater zone, this ratio can be larger, resulting in larger retardation factors; however, the retardation factor for flow through planer fractures is defined as (Freeze and Cherry 1979)

$$
R=1+\frac{2 K_{f}}{2 b}
$$

where

$\mathrm{K}_{\mathrm{f}}=\mathbf{a}$ fracture sorption coefficient defined as the ratio of the mass of sorbed solutes per unit area of fracture surface to the concentration in solution, $2 b=$ fracture aperture.

Values for $\mathrm{K}_{\mathrm{f}}$ have not been determined for the $\mathrm{ORR}$. Because diffusion can transfer contaminants from fractures to the marrix, a combination of eq. (3.4) and (3.5), coupled 
with diffusive transpon, is necessary to simulate reactive contaminant transport in the groundwater zone of the ORR.

Sorption coefficients are specific to the solute, the soil, and the ambient water chemistry (e.g., $\mathrm{pH}$, ionic strength, redox); thus, measurement involves intensive lab and field work. Nonetheless, Kds have been estimated for certain radionuclides in shales on the ORR, as shown below. (Rothschild et al. 1984; Davis et al. 1984; Meyer et al. 1987; Jacobs 1989). The retardation factors shown in Fig. 3.13 assume a granular porous media with a ratio of bulk density to porosity of 10 .

ORNL-DWG $92-9379$

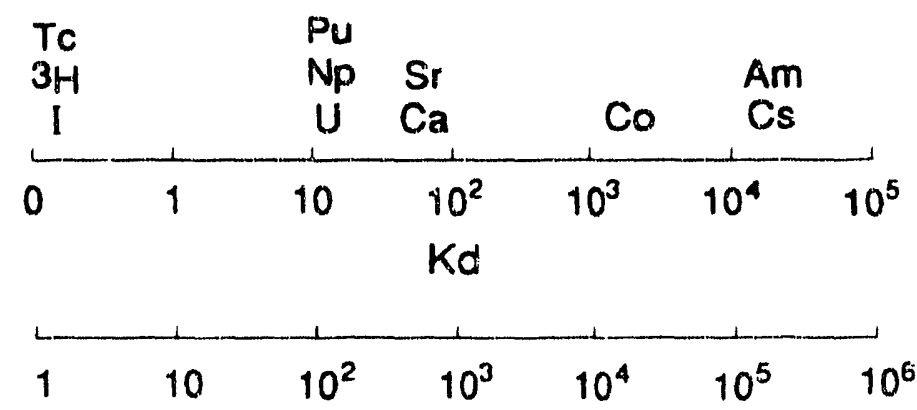

$\mathrm{R}$

Fig. 3.13. Approximate order of magnitude of laboratorymeasured sorption coefficients $(\mathrm{Kd})$ and calculated retardation factors $(R)$ for selected radionuclides and calcium and soil and rock materials of the ORR. A ratio of bulk density to porosity of 10 was assumed for computing $R$.

Tc, $\mathrm{I}$, and ${ }^{3} \mathrm{H}$ have the lowest $\mathrm{Kds}$, and are considered mobile. Some transuranics and strontium ( $\mathrm{Sr}$ ) have $\mathrm{Kds}$ similar to $\mathrm{Ca}$ and are moderately sorbed. Cobalt $(\mathrm{Co})$, americium (Am), and cesium (Cs) have strong sorption characteristics but can be transported on colloids in waters of high ionic strength. Sorption properties of organic contaminants also range over several orders of magnitude and are strongly related to the organic content of porous media. Data are not available from ORR soils, but measurements elsewhere suggest that TCE and PCB have low Rs $(<10)$; pesticides are often strongly sorbed. Kds tend to increase with weathering on the ORR because of increased surface area and exposure of clays (Rothschild et al. 1984).

Laboratory measurements of $\mathrm{Kd}$ on crushed samples typically overestimate sorption capacity and may not represent field-scale processes. For modeling purposes, any $\mathrm{Kd}>10$ or 100 would be considered large, and an upper bound of 100 on $\mathrm{Kd}$ is more reasonable to 
or 100 would be considered large, and an upper bound of 100 on $\mathrm{Kd}$ is more reasonable to use. In addition, measurements have not been made comparing $\mathrm{Kd}$ of a fracture surface with that of the matrix or estimating available surface area of fractures. It is expected that $R$ of fracture surfaces is much lower than $\mathrm{R}$ of the matrix. The rock matrix and matrix diffusion play a key role in solute retardation because the surface area of the matrix is much larger than fracture surface area, so the sorption capacity of the matrix is significant.

Finally, solutes sorbed in the matrix as well as on fractures can be flushed out by water dilute in the species of concern or by water of a chemical character, such as $\mathrm{pH}$, that results in a change in the $\mathrm{Kd}$. An understanding of $\mathrm{Kd}$ is critical to predicting contaminant behavior, especially under treatment scenarios that alter $\mathrm{Kd}$. 


\section{SUMMARY, CONCEPTS OF FLOW}

During the last ten years an impressive amount of hydrogeologic data has been collected on the ORR; however, relatively few data interpretations have been published. Table 4.1 is a summary of key concepts, derived from interpretations of the available data, that describe in general terms the hydrogeology of the ORR. Included are lines of evidence that support a given concept as well as some negating evidence. Major uncertainties as well as implications for waste management and environmental restoration are included. This is meant to be a "living" table, which should evolve as new data are collected and analyzed. 


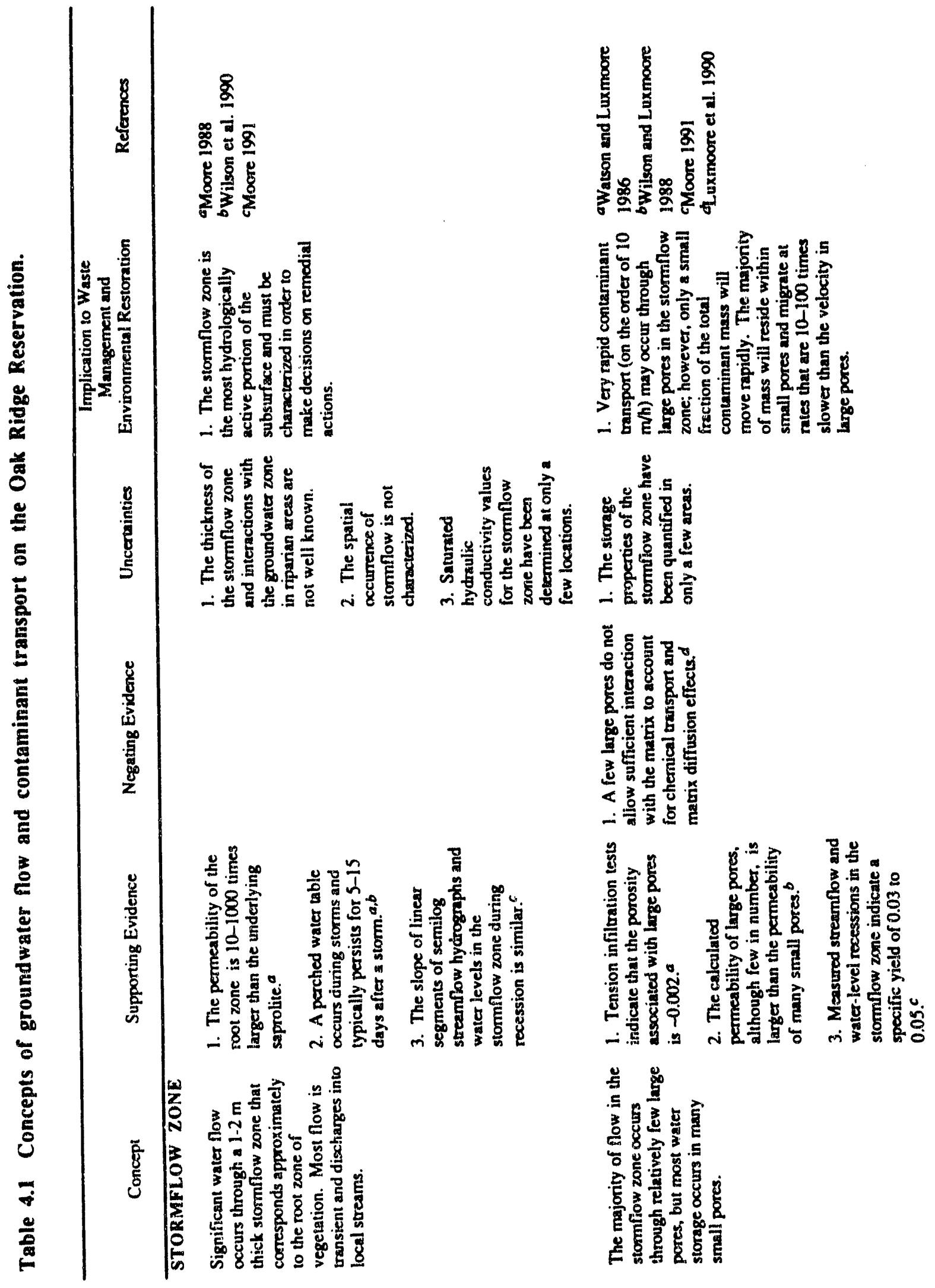




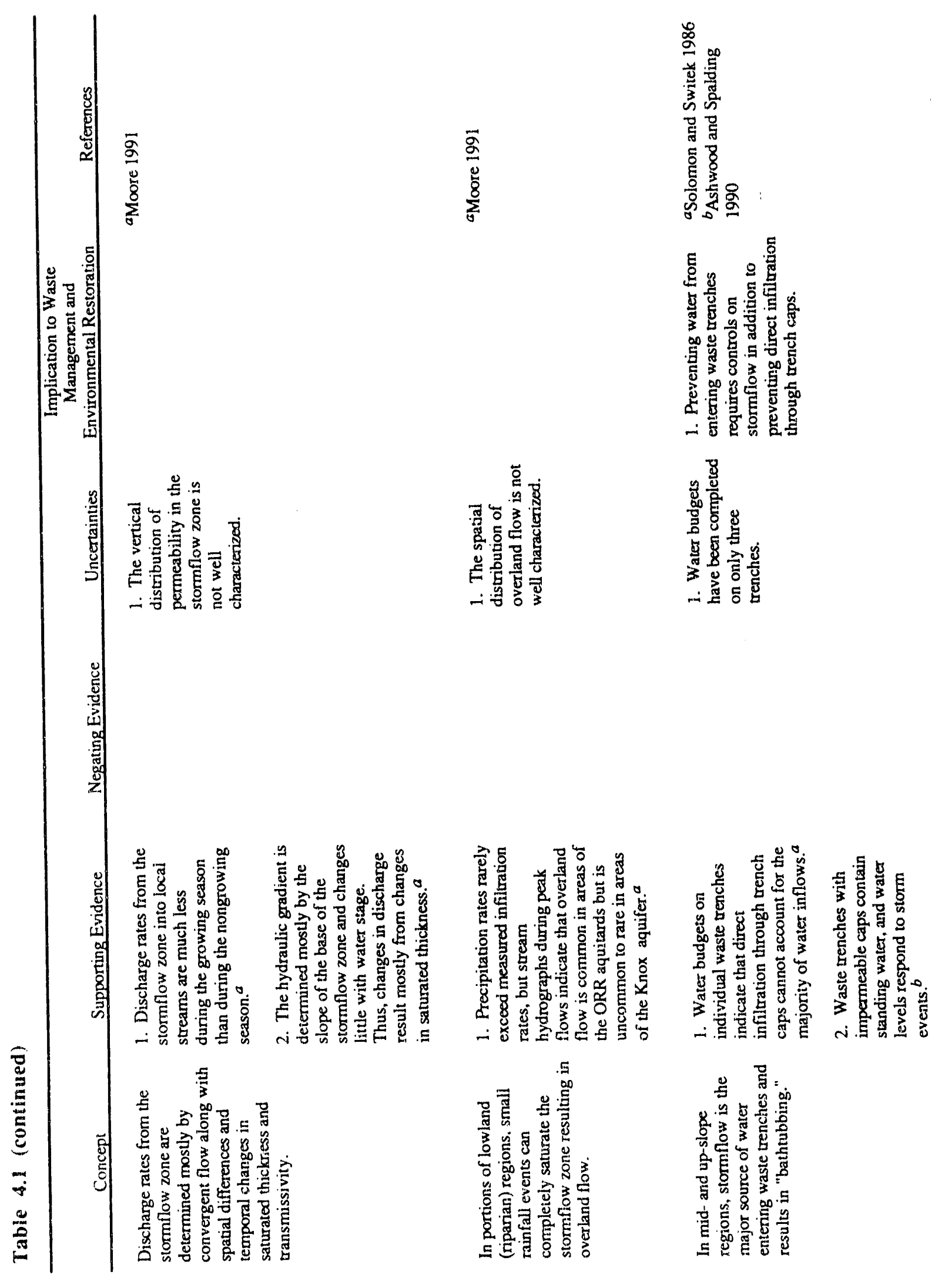




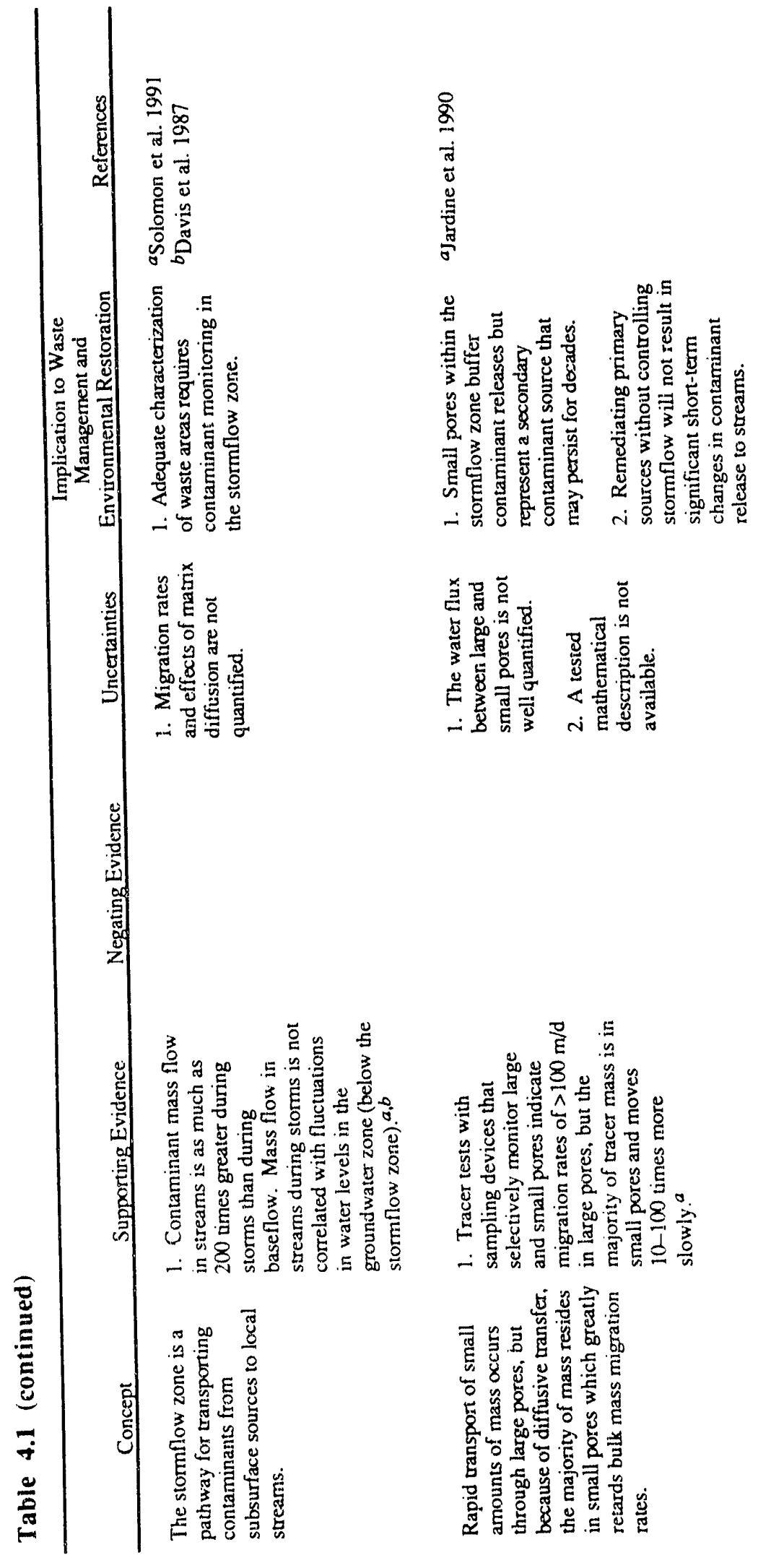




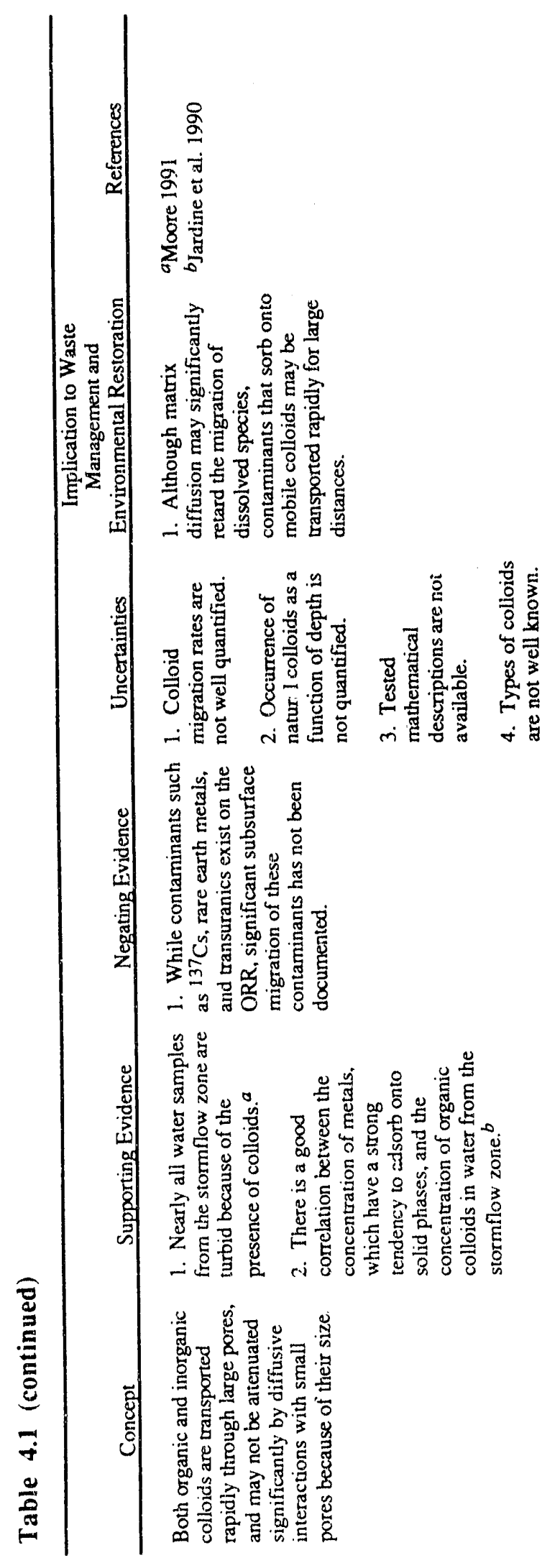




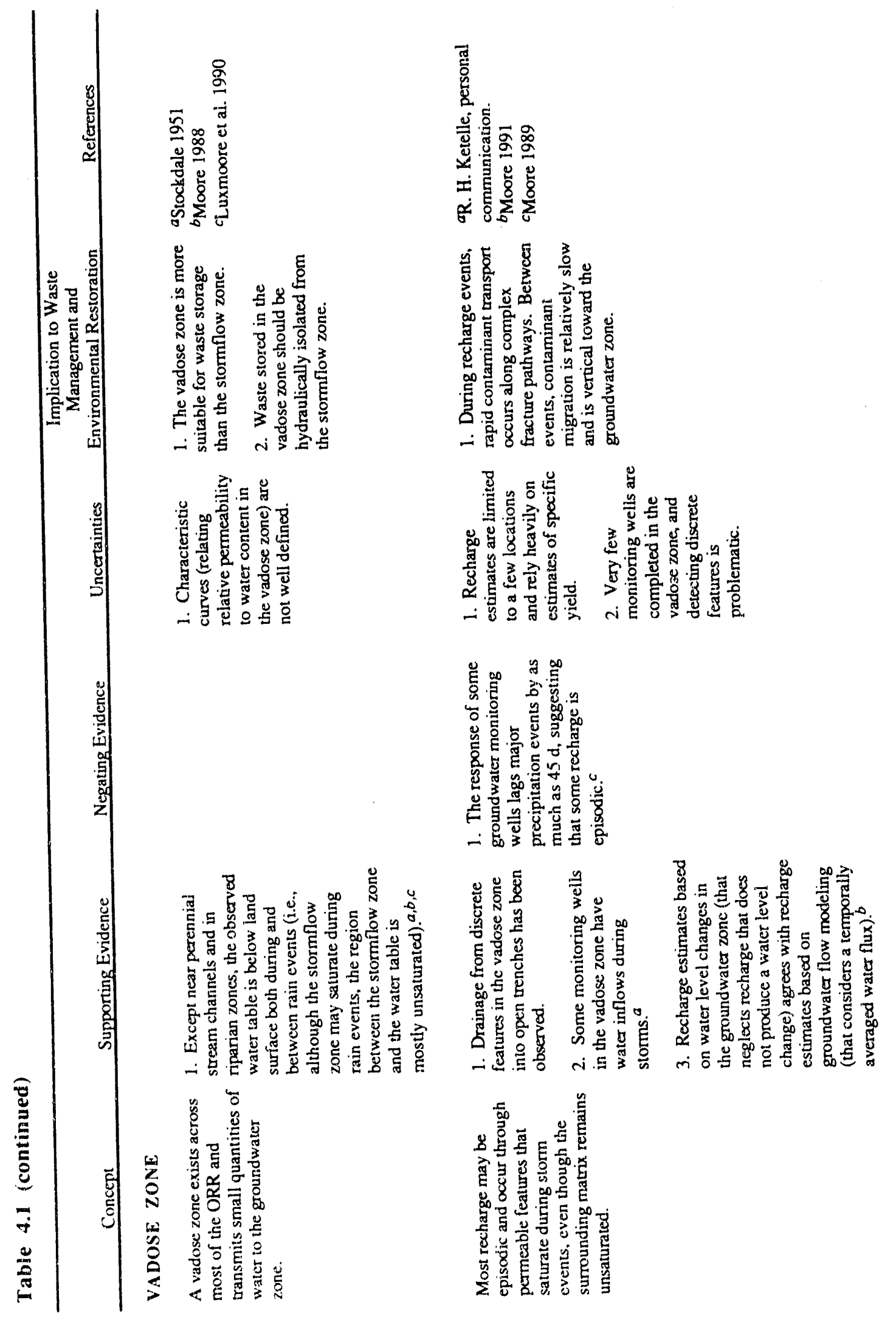




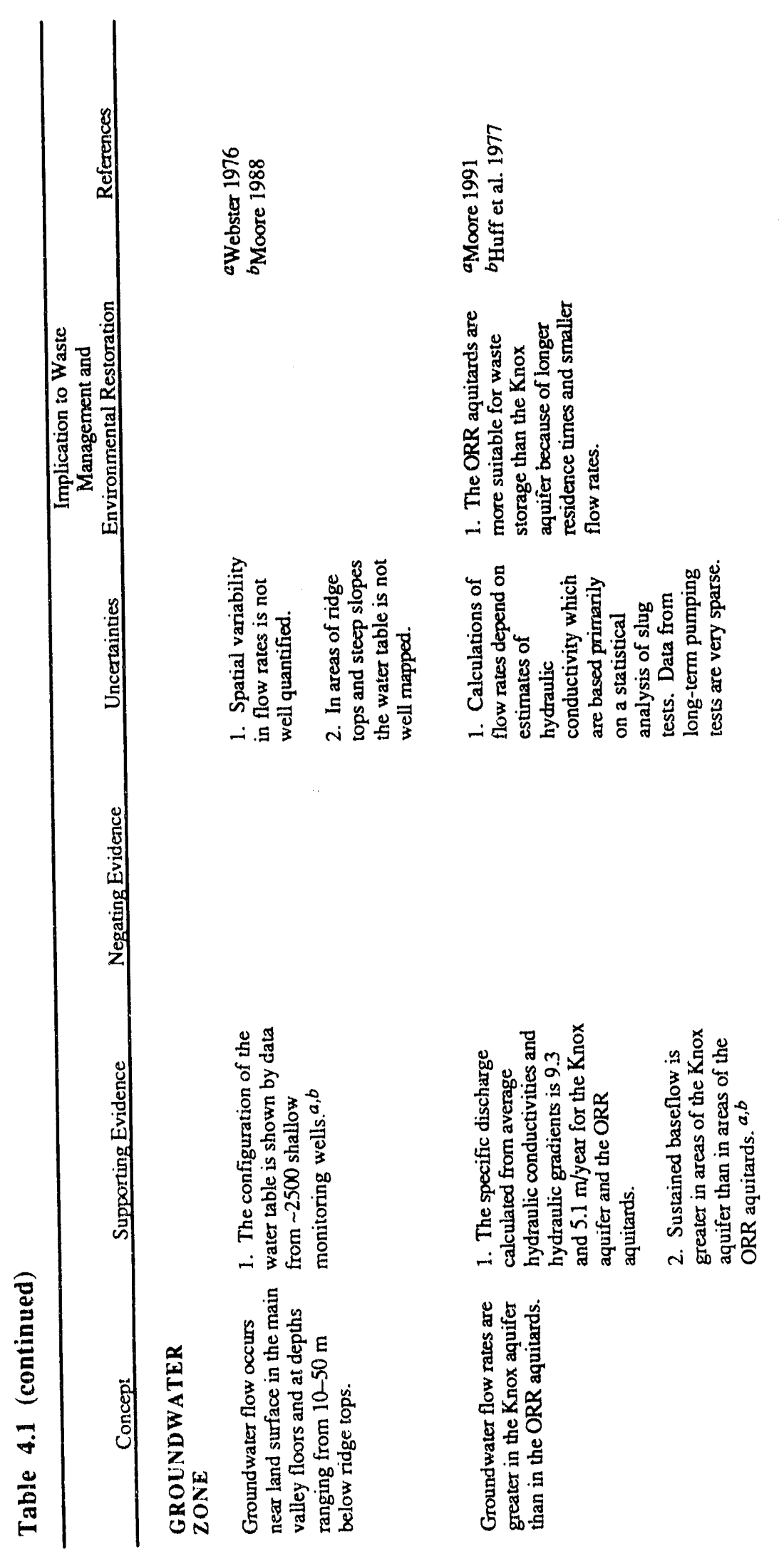




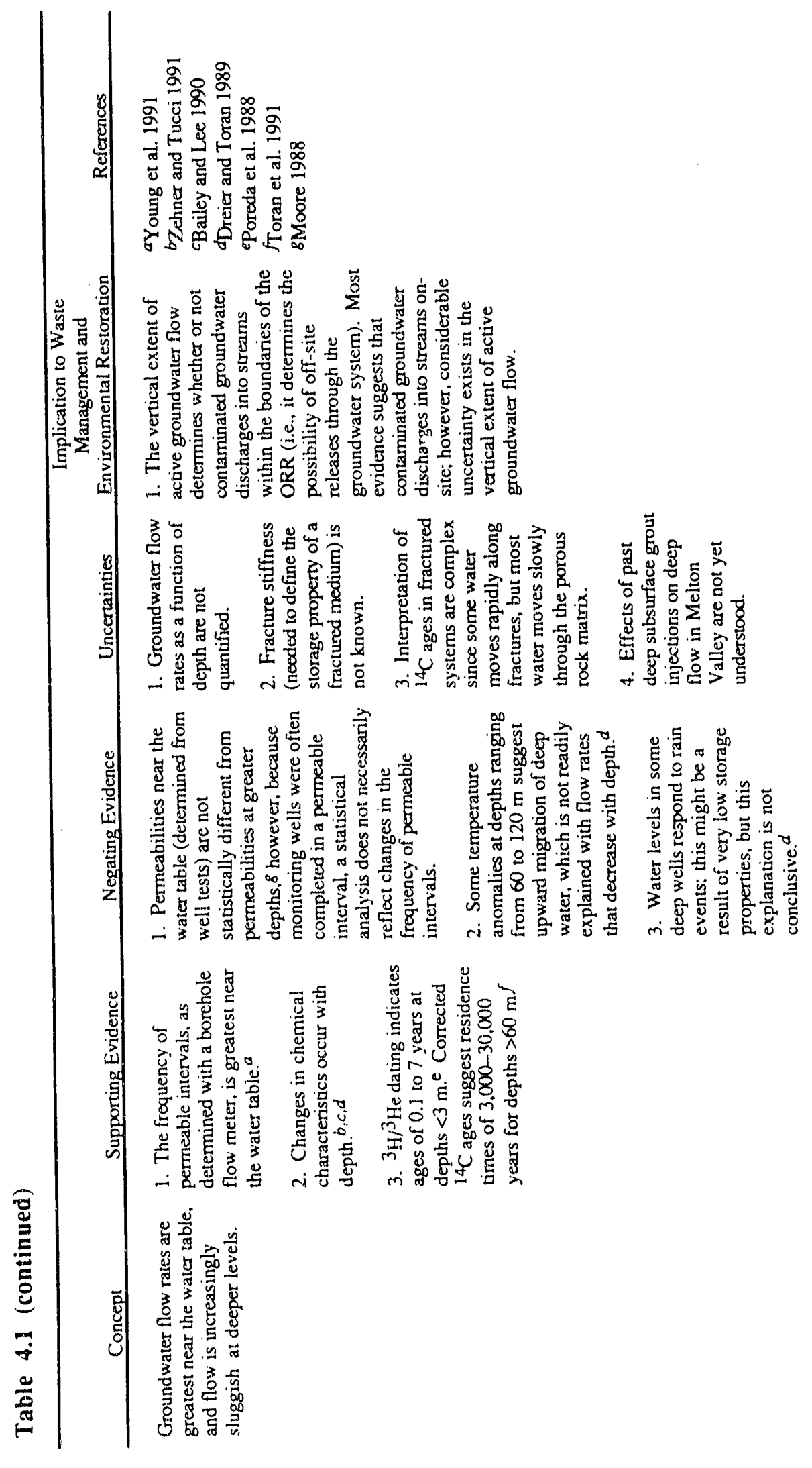




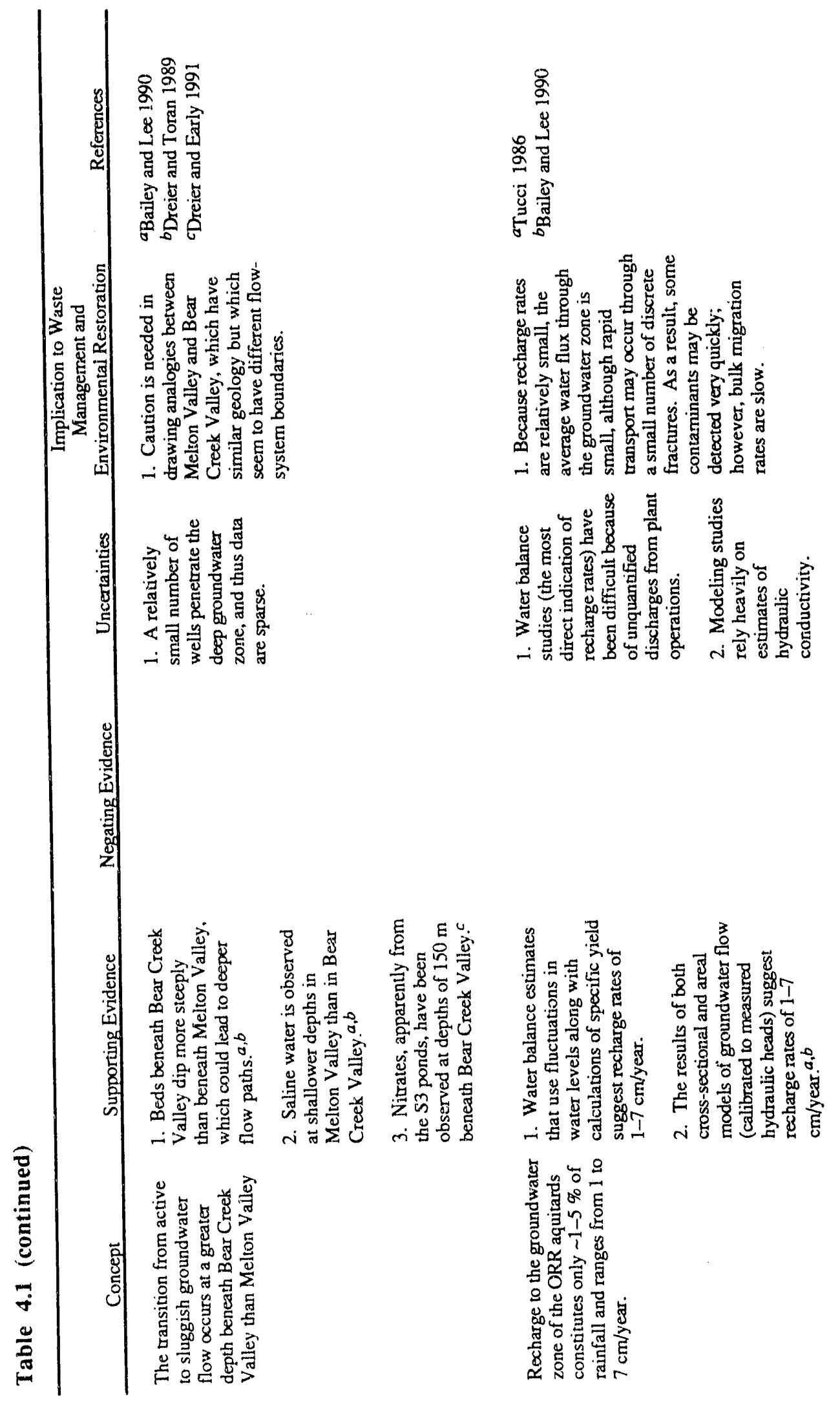




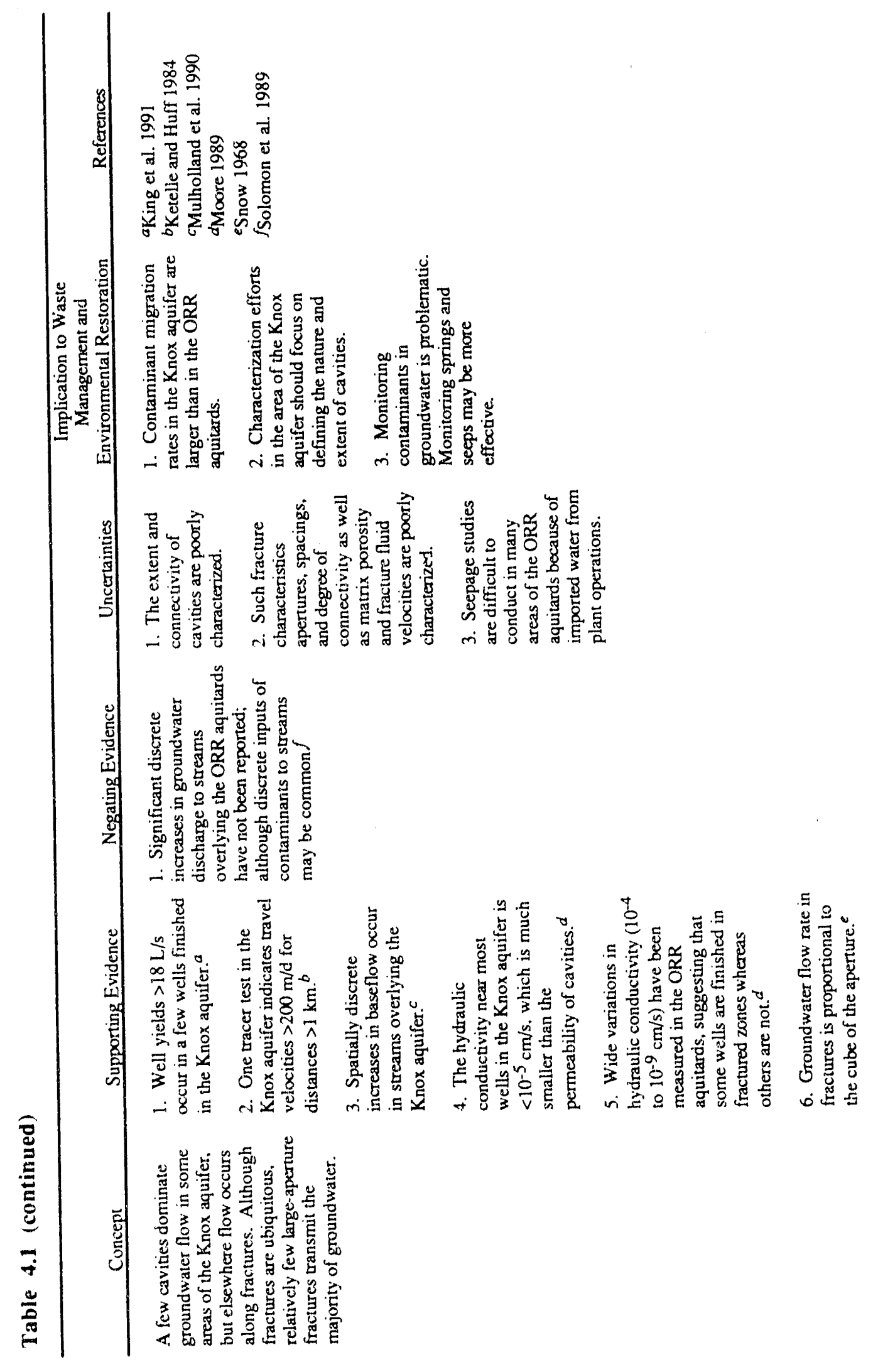




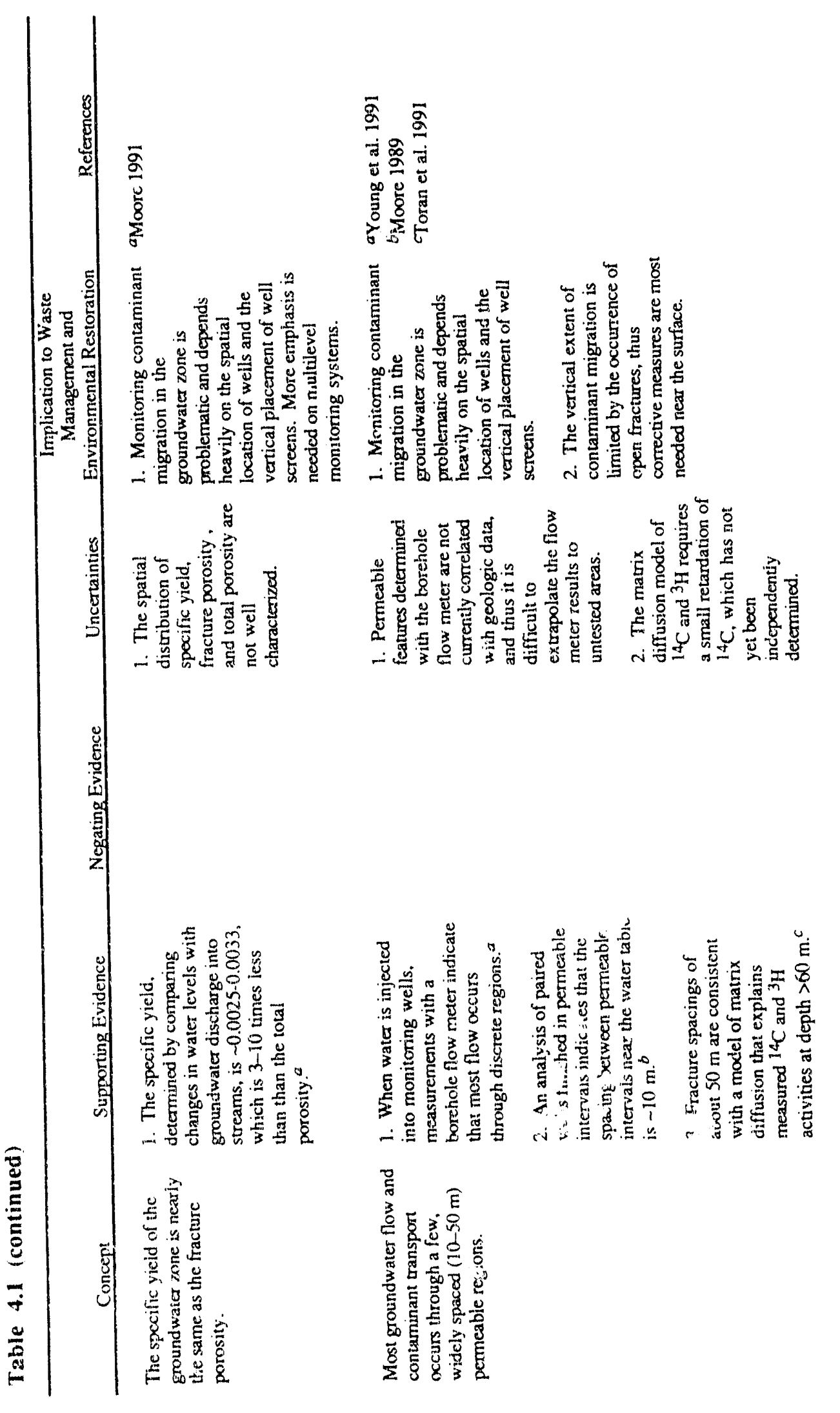




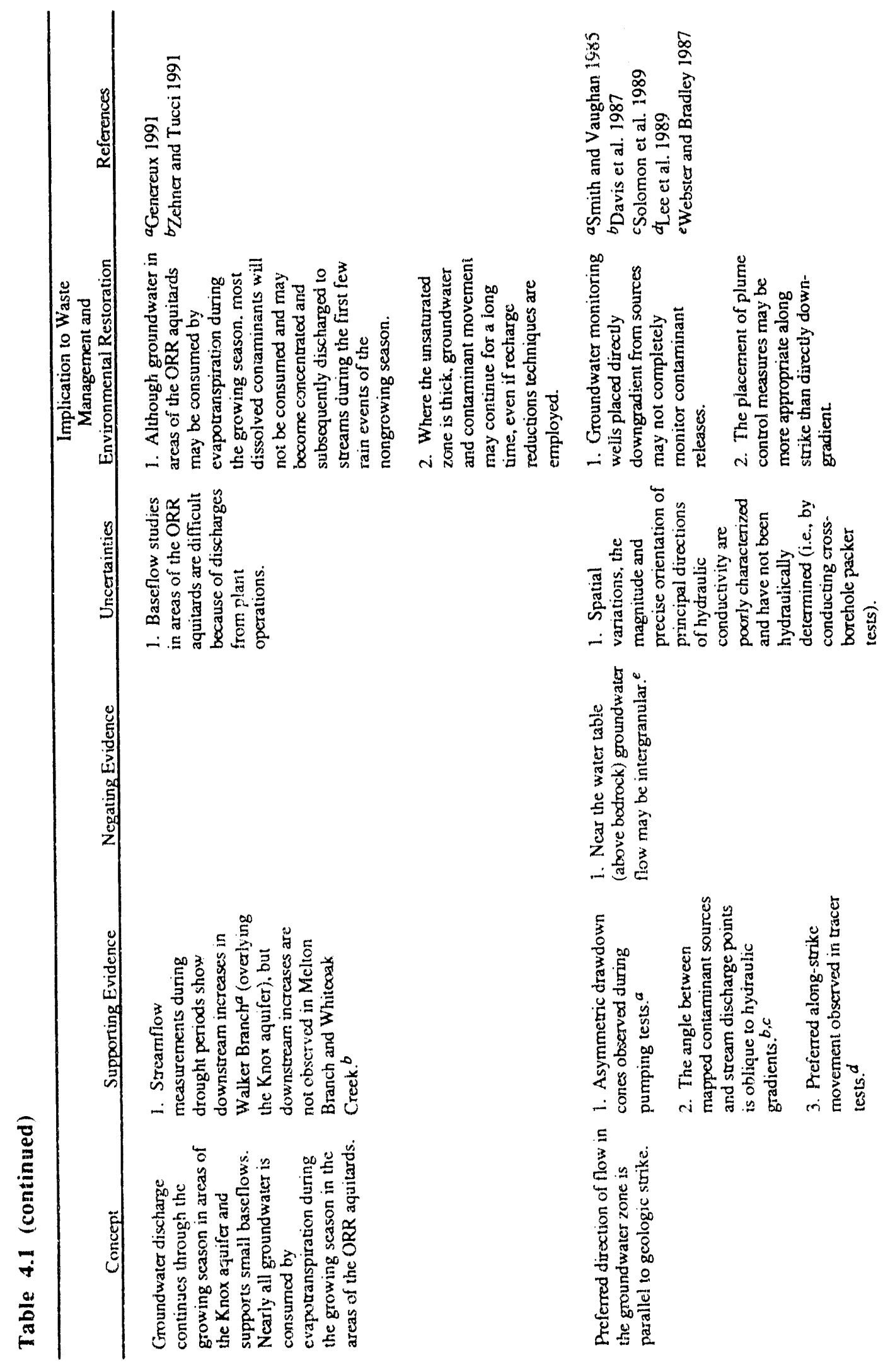




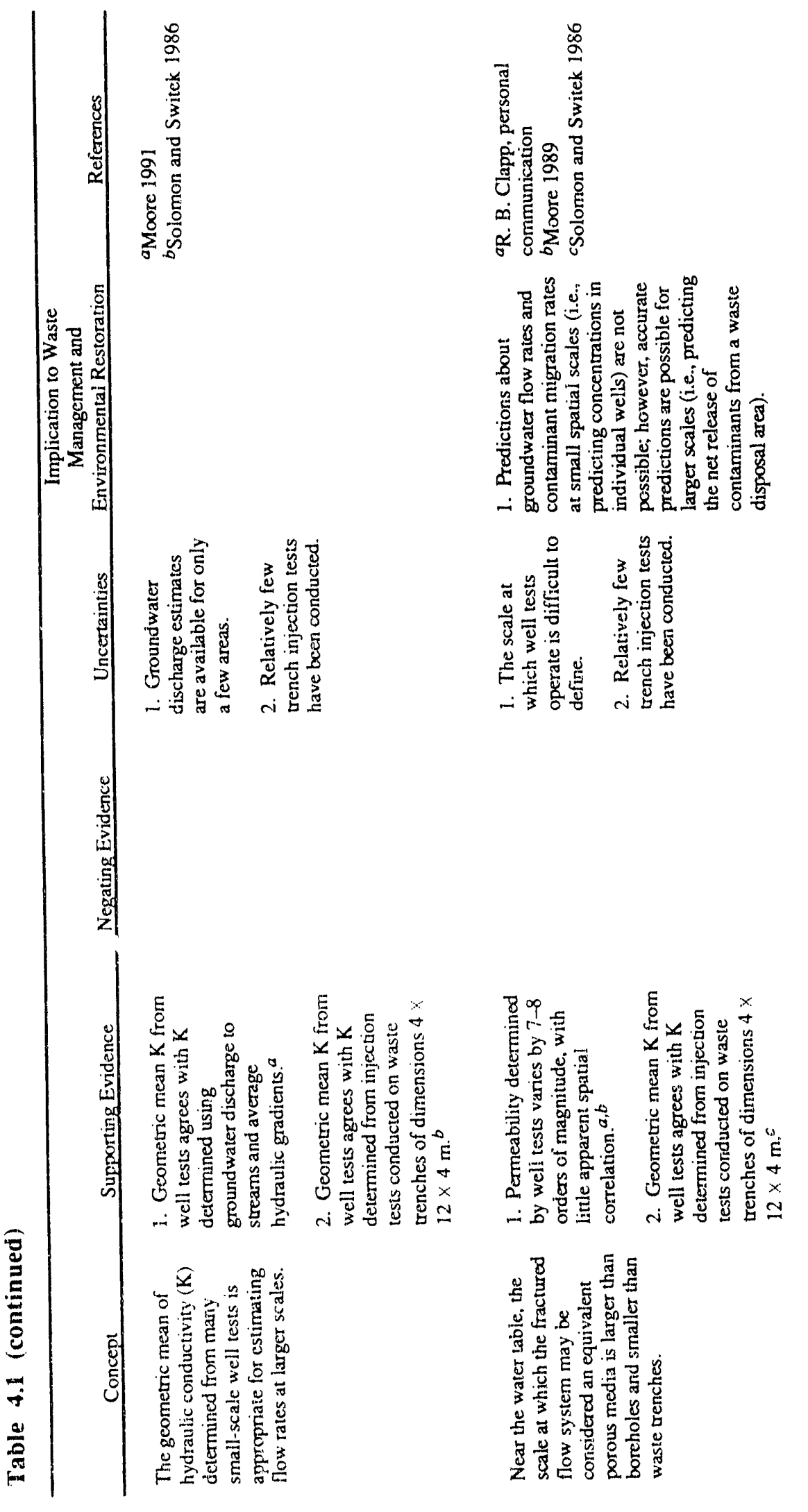




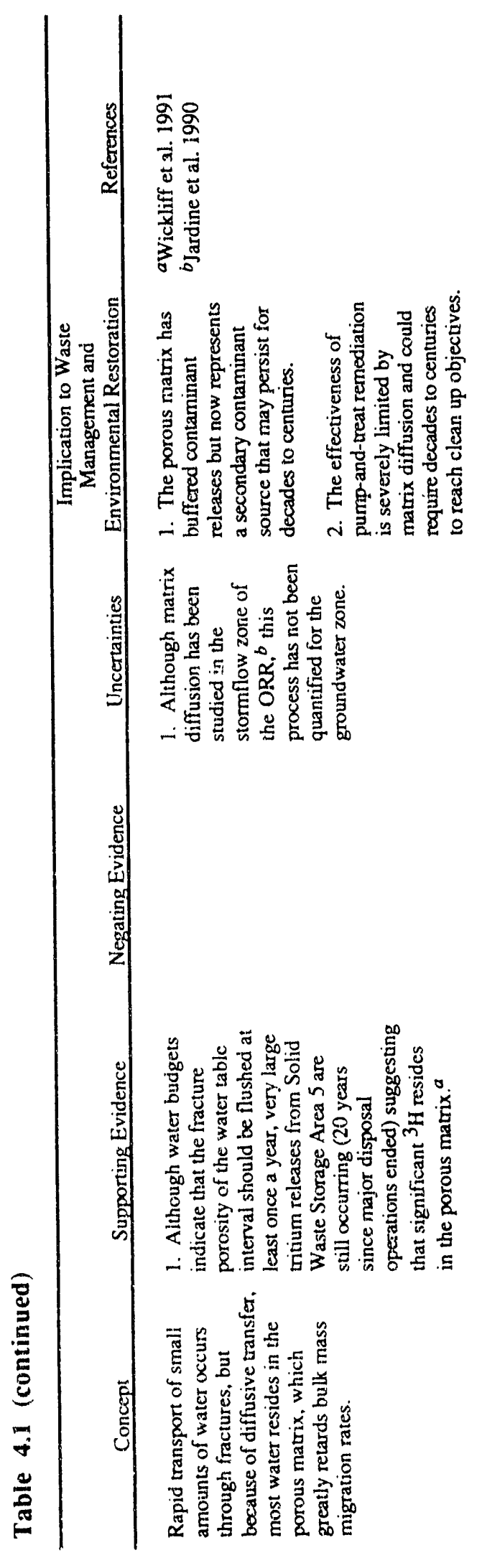




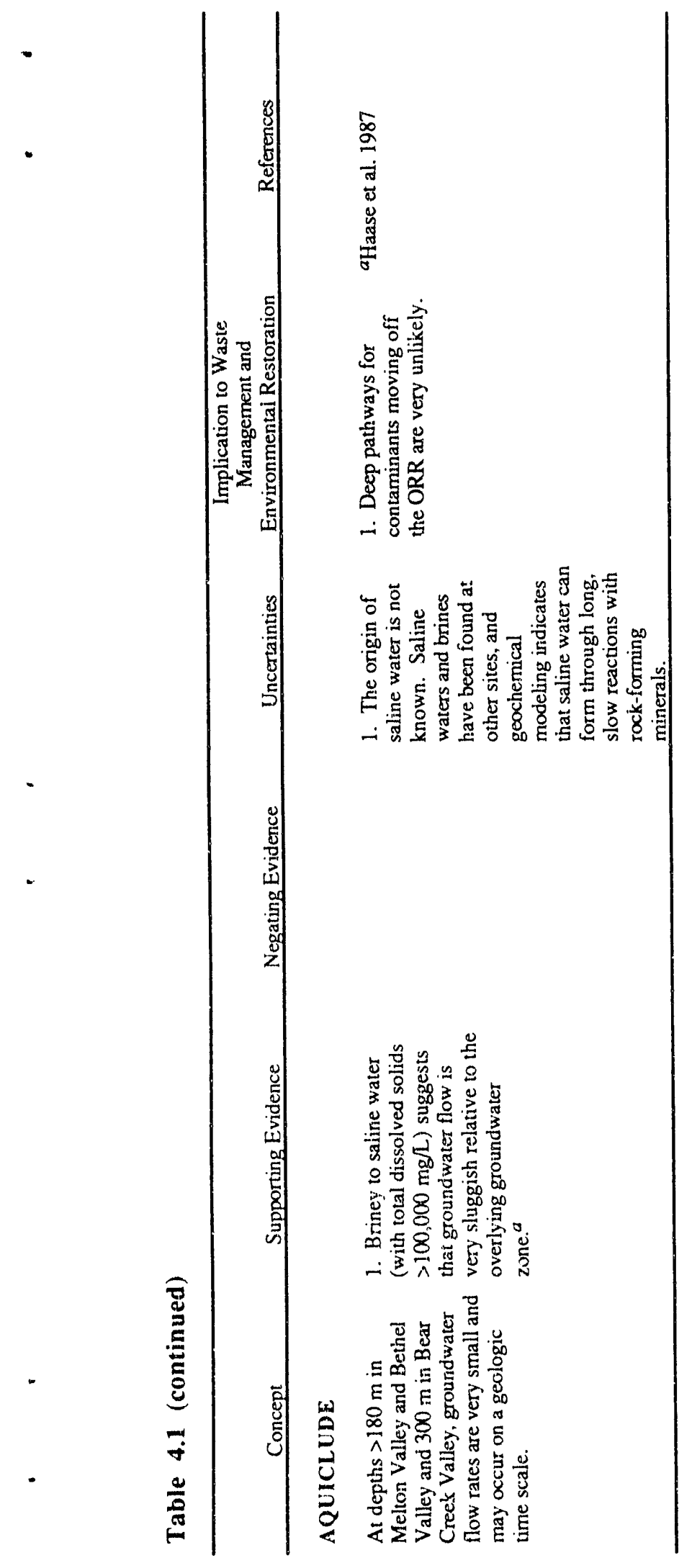




\section{IMPLICATIONS TO ENVIRONMENTAL RESTORATION AND MONITORING AND TO WASTE MANAGEMENT}

\subsection{SRACE WATER}

- Mosi reguiatory compliance efforts on the ORR are directed towards groundwater, but a major premise of this report is that flow paths above the water table conduct the bulk of subsurface flow. Also, virtually all groundwater follows short flow paths in the watertable interval and discharges to adjacent drainageways. Mainly for these reasons, surface water monitoring provides more valid contaminant flux information than does monitoring of groundwater by wells.

- A related conclusion is that with one or two possible exceptions, all subsurface waterborne contaminants are eventually discharged to streams within the boundary of the ORR and all contaminants are ultimately discharged to the Clinch River.

- The most representative and unambiguous information about contaminant movement and discharge from a waste site can be ohtained from surface-water records on nearby drainageways, where the nonhomogeneities of the subsurface materials within the basin are integrated.

- Because pathways for off-site release of waterborne contamination are through surface water, surface-water monitoring on the sub-basin scale is most relevant for characterizing waterborne contaminant flux.

- Waste-area characterization activities such as detailed seep, spring, and surface-water monitoring that effectively integrate over larger vo'umes yield more useful results than small-scale (i.e., borehole) monitoring.

\subsection{STORMFLOW ZONE}

- The stormflow zone is the most hydrologically active portion of the subsurface and must be characterized in order to make decisions on remedial actions.

- Because of sharp vertical contrast in permeability, as much as $95 \%$ of subsurface flow is 
quickly discharged through short, transiently saturated flow paths to adjacent surface drainageways.

- Adequate characterization of waste areas requires contaminant monitoring in the stormflow zone.

- Nearly all of the wet-silo, bathtubbing-trench, and ineffective-cap problems on the ORR are caused by lateral flows of water in the stormflow zone.

- Studies of contaminant release from waste areas to streams indicate that contaminant mass flow can increase by a factor of as much as 200 during rain events.

- The relative importance of contaminated stormflow discharge compared with contaminated groundwater discharge from a waste area decreases as the operational age of the waste area increases.

- When the stormflow zone saturates during rain events, transport velocities of $12 \mathrm{~m} / \mathrm{h}$ or more can occur through large pores. However, only a small fraction of the total contaminant mass moves rapidly. Most mass resides within small pores and migrates at rates $10-100$ times slower than the velocity in large pores.

- Preventing water from entering waste trenches requires controls on stormflow in addition to prevention of direct infiltration through use of trench caps.

- Small pores in materials of the stormflow zone buffer contaminant releases but represent a secondary contaminant source that may persist for decades.

- Remediating primary waste sources without controlling stormflow will not result in significant short-term changes in contaminant release to streams.

- Although the transport processes--ion exchange, ion sorption, and matrix diffusionmay significantly retard the migration of dissolved species, contaminants that sorb onto mobile colloids may be transported rapidly for large distances. 


\subsection{VADOSE ZONE}

- The vadose zone is more suitable for waste storage than the stormflow zone.

- During recharge events, rapid contaminant transport occurs along complex pathways. Between events, contaminant migration is relatively slow and is vertical toward the groundwater zone.

\subsection{GROUNDWATER ZONE}

- Most of the waste management areas of the ORR are in areas underlain by the aquitards (mainly Bear Creek Valley, head of East Fork Poplar Creek valley, Bethel Valley, Melton Valley), where $<5 \%$ of subsurface water reaches the groundwater zone. Once water reaches the groundwater zone, flow continues to be inhibited by vertical decrease in permeability, so that the shallowest part of the groundwater zone, the water table interval, carries the bulk of the $4 \mathrm{~cm} /$ year or less of flow in the saturated zone to discharge to local surface waterways.

- Monitoring contaminant migration in the groundwater zone depends heavily on the vertical placement of well screens as well as on location with respect to permeable fractures or cavities through which contaminants move. Because flow pathways are difficult to identify unambiguously in the field, they add uncertainty to monitoring. A traditional monitoring well, for example, may not intersect a fracture or solution conduit pathway. Or concentrations in a fracture may be diluted by mixing with matrix water, resulting in underestimated solute transport rates. Groundwater monitoring wells placed directly downgradient from contaminant sources will not monitor all contaminant releases from these sources.

- Because they must be sensitive to small numbers, measurements are difficult in low permeability units. The response time for measurements is inordinately large. For example, in some wells dewatered during drilling in low permeability units on the ORR, the water levels may take 5 years and longer to return to steady-state head values. In laboratory measurements of $\mathrm{K}$, low permeabilities are typically dealt with by using very small samples or very large head gradients across the sample to reduce measurement time. Both of these techniques create conditions that are not representative of the natural low permeability setting, and the validity of the results is controversial. 
- Based on radioisotope measurements, water residence times in the water table interval in the ORR aquitards (general thickness $\sim 3 \mathrm{~m}$ ) are relatively short-from a few weeks to less than ten years. In this interval, fractures are more hydraulically interconnected than in underlying intervals.

- The vertical extent of active groundwater flow determines whether contaminated groundwater discharges into streams within the boundaries of the ORR (i.e., it determines the possibility of off-site releases through the groundwater system). Most evidence indicates that contaminated groundwater discharges into streams on-site; however, uncertainty remains in the vertical extent of active groundwater flow.

- In the aquitards, the vertical extent of contaminant migration is limited by the depth of occurrence of open fractures.

- In the intermediate and deep intervals, ${ }^{13} \mathrm{C}$-corrected ${ }^{14} \mathrm{C}$ ages range from 3,000 to 30,000 years; however, very low levels of ${ }^{3} \mathrm{H}$ (which could not have infiltrated more than 50 years ago) have been detected. Flow in fractures may account for the presence of small quantities of ${ }^{3} \mathrm{H}$ (traveling along fast flow paths in the fractures) with the long residence times of water in the matrix, implied by the ${ }^{14} \mathrm{C}$ results.

- Because recharge rates are relatively small, the average water flux through the groundwater zone is small (although rapid transport may occur through a small number of discrete fractures).

- Meaningful description of groundwater flow must be made at scales larger than those sampled by individual boreholes on the ORR.

- Characterizing hydraulic properties of karst aquifers is particularly difficult because of their extreme and abrupt variation within short distances. The utility of wells for aquifer characterization or for monitoring for contaminant presence is limited; in most cases, wells are useful only for water-level information, unless they penetrate conduits shown to be connected to the facility site. As the easiest and most reliable points at which to monitor groundwater quality, Quinlan (1989) recommends the use of springs and any directly accessible cave streams, along with dye tracers introduced at the facility site being investigated, to demonstrate connection to the site. 
- Predictions about groundwater flow rates and contaminant migrations rates at small spatial sampling scales (concentrations in individual wells) are not possible; however, accurate predictions are possible for larger scales (i.e., predicting the net release of contaminants from a waste disposal area).

\subsection{TRANSPORT PROCESSES}

- Transport processes--ion exchange, ion sorption, and matrix diffusion--are likely to have created secondary contaminant sources downgradient of waste sites, and in the case of old waste sites, the secondary source may contain a greater mass of contaminants than the original site.

- The effectiveness of pump-and-treat remediation is severely limited by matix diffusion; coupled with the low permeabilities of the groundwater zone, this means that decades or centuries could be required to reach clean-up objectives. Also, since pump-and-treat technology in low permeability system: "*.pically enhances fluid velocities by less than a factor of 5, contaminant removal time is not likely to be significantly less than the time over which contaminants were diffusing into the matrix and could be substantially longer.

- The porous matrix of subsurface materials has buffered contaminant releases but now represents a secondary contaminant source that may persist for decades.

- Although rapid transport occurs in the stormflow zone, contaminant mass flux is greatly reduced by diffusive exchange between macropores and less permeable micropores.

- When contaminant sources such as trench leachate are of finite duration, transport processes can significantly attenuate peak concentrations at discharge points.

- The large difference between the first-arrival velocity and the migration rate of peak concentrations that results from diffusive transport processes has important implications to waste management and environmental restoration. Average contaminant residence time can be many times greater than if diffusive transport processes were not operative. Instantaneous releases such as from container failure are buffered by diffusion into less 
permeable regions, allowing detection of contaminants before substantial migration occurs.

- For contaminants that are not transformed by processes such as radioactive decay or biodegradation, only the time element is modified for a total contaminant release for a given source function (i.e., time variations in flux from the waste source); the release is not otherwise affected by transport processes. If time-dependent contaminant transformations occur, however, the added residence time afforded by transport processes can substantially reduce the total contaminant release.

- The short-term effectiveness of remedial actions aimed at reducing the discharge of contaminants from subsurface to surface-water systems depends critically on the mass of contaminants that are presently stored within the porous matrix. If the contaminant mass within the matrix is small, source-level remediation such as grouting, compaction, and in situ vitrification would resu't in reduced contaminant discharge shortly after remediation. If the contaminant mass in the matrix is large, only remediations that eliminate both primary sources (e.g., trench leachate) and secondary sources (i.e., desorption and diffusion from storage in the matrix) will effectively reduce contaminant releases.

- The seriousness of dense nonaqueous phase liquids (DNAPLs) contamination results primarily from two characteristics of DNAPL constituents: (1) their low regulatory concentration limit and (2) their small solubility in groundwater. Because of the low solubility, when pure phase DNAPLs are present in the subsurface, removal by dissolution into groundwater is extremely ineffective.

- DNAPLs penetrate into fractures when the DNAPL pressure and the fracture aperture are sufficiently large. Once DNAPL enters a fracture, it migrates along the fracture, leaving a residual coating along the fracture walls and pockets disconnected from the primary body of migrating DNAPL. It is important to note that alterations of the hydrogeologic system, such as borehole construction and groundwater pumping, can remobilize pure phase DNAPLs. Thus, investigation of DNAPL contamination is very difficult and must be conducted carefully.

- Despite the uncertainties about parameterization, there is ample evidence that colloid 
transport occurs. Breakthrough of colloids can occur faster than a conservative tracer. The preference of colloids for fast flow paths may indicate fracture flow travel paths that might not be evident from the smooth breakthrough of a solute tracer traveling through the matrix.

- Ultimately, remediation decisions depend on the potential risk assigned to a given waste site. Very large uncertainties exist in potential contaminant re'eases from primary sources because of inadequate inventories and incomplete uriderstanding of leaching and container failure rates. The greater level of uncertainty results in assignment of larger risk. The risk associated with uncertainties in release rates is reduced when the medium in which transport takes place buffers any catastrophic releases from waste sources. The risk associated with these uncertainties is substantially reduced where monitoring assures early warning of catastrophic failures and where retardation processes are significant because transport processes provide buffering of all contaminants.

\subsection{GENERAL IMPLICATIONS}

- Caution is needed in drawing analogies between Melton Valley and Bear Creek Valley, which have similar geology but appear to have different flow-system boundaries; that is, the active flow system appears to be at substantially greater depth in Bear Creek Valley.

- The ORR aquitards are more suitable for waste storage than the Knox aquifer.

- Contaminant migration rates in the Knox aquifer are much larger and flow paths are potentially much longer than in the ORR aquitards.

- Characterization effs rts in the area of the Knox aquifer should focus on defining the nature and extent of water-bearing cavities.

- In areas of the ORR aquitards, groundwater is consumed by eva $a_{\mathrm{r}}$ otranspiration during the growing season, and dissolved contaminants may become concentrated, to be discharged to streams during the first few rain events of the following nongrowing season. 


\section{RECOMMENDATIONS FOR FURTHER INVESTIGATIONS}

Several areas of uncertainty or of incomplete evidence require investigation to verify the more conjectural premises presented in the model as it is described in this report. This section summarizes some of the key uncertainties that should form the basis for continuing hydrologic investigations on the ORR. To reiterate the significance of these recommendations to environmental activities on the ORR, as described in the previous section, it is necessary to understand the contaminant flow paths and the characteristics of physical and chemical processes in the hydrologic zones in order to control contaminant migration. The lack of field data is the most serious limitation to quantifying and modeling fracture flow and transport. Research in this area is limited, but it is clear that standard porous media methods are inadequate to characterize fractured rock. The standard methods must be supplemented and all data must be viewed within the framework of a fractured rather than a granular porous medium.

\subsection{GENERAL RECOMMENDATIONS}

- Demonstrate the relation between water chemistry time/mass functions for a variety of settings and conditions in the stormflow zone and the water table interval, and water chemistry in streams through streamflow hydrographs during and following rain events.

- Determine actual controls on the location and extent of contaminant migration and relationships to the hydrologic zones.

- Measure porosity, specific yield, fracture spacings, and contaminant concentrations in matrix materials.

- Acquire information necessary to identify best-location, least-cost site selection and design for waste storage and disposal facilities. Include information required for management and control of future leaks and spills and for contaminated sediments in riparian areas

- Develop water budgets that quantify all flow processes on the ORR, including overland runoff, stormflow, and ground water flow. This requires concurrent, continuous monitoring of natural streamflows and records of water levels in the stormflow and groundwater zones. 
- Synthesize an improved digital flow model for the ORR, consisting of at least the stormflow zone, the water table interval, and deeper levels; include capability to incorporate effects of sorption, matrix diffusion, possibly dilution by recharge, and dispersion.

- Develop an erosion and sediment transport digital model for identification of critical areas for White Oak Creek, East Fork Poplar Creek, Clinch River and for evaluation of control alternatives for contaminated sediments.

\subsection{STORMFLOW ZONE}

- Further investigate and document the relative importance of the stormflow zone in contaminant transport.

- Investigate the form in which contaminants migrate through the stormflow zone as to whether associated with colloids or in solution.

- Determine spatial variations in hydrologic characteristics of the stormflow zone across the ORR.

\subsection{GROUNDWATER ZONE}

- Establish the number, thickness, and accurate hydraulic conductivity and transmissivity data for pernieable intervals in the groundwater zone.

- Correlate number and thickness of permeable intervals with water-level drawdown patterns from long-term pumping tests, a requirement for planning measures dealing with contaminant plumes.

- Investigate the association between measureable geologic properties, such as fracture characteristics, and the development of hydrologically active zones.

- Document the presence and hydrologic characteristics of the water table interval and its relative thickness in areas of shallow and steep slope. Compare with thickness of permeable intervals at deeper levels. 
- Accurately determine directions of groundwater flow as influenced by fractures, and compare to directions inferred from water table contour maps.

- Obtain more conclusive evidence for shallow groundwater and contaminant circulation, discharge to closest surface drainageways-including measurements of ${ }^{14} \mathrm{C}$, stable isotopes, water-level fluctuations in deep wells, geochemical modeling of water types and concentration changes along flow paths.

- Improve understanding of conduit flow in Knox aquifer, including vertical and areal extent, connectivity, and water chemistry.

- Reduce uncertainties regarding location, extent, and relative concentrations of contaminants in riparian areas, where they may be concentrated by natural processes.

- Obtain evidence conceming flow path limitations in the deep interval of the groundwater zone.

\subsection{RECOMMENDED APPROACHES}

Specific investigations and priority of work are detailed in other documents, but the direction of investigation is clearly indicated in the concepts described in this report. These concepts form a paradigm that will evolve and be adjusted as the investigations proceed. Although the hydrogeologic setting of the ORR is complex, continued development and proof of concepts of flow and contaminant migration will result in improvements in waste remediation and management techniques. Eventually, the ORR could become a prototype for remediation and management of wastes in complex settings.

Hydrologic data acquisition: Formulate a strategy for field data acquisition, with the objective of resolving remaining uncertainties. In order to minimize installation of new sampling points, select field study areas in which boreholes and continuous surface water records are available, and plan activities in conjunction with Remedial Investigation/Feasibility Study programs investigations.

Model:..g: To enhance interpretation of field data, computer models of flow, transport, and geochemical processes will continue to be constructed. Future efforts will emphasize more 
complex constructs than those used in the past and will include fracture flow with matrix diffusion, fully three-dimensional flow fields, and density-driven flow.

Geochemical Investigations: By use of mure advanced sampling equipment, such as multiport installations, groundwater geochenistry will be valuable in defining flow paths and confirming or developing hypotheses about groundwater parameters. For example, distinguishing deep and shallow flow systems by water types may provide information on flow rates. Geochemical tracers may prove a key method of parameterizing matrix diffusion through natural processes. 


\section{GLOSSARY OF TERMS USED IN REPORT AND OTHER BACKGROUND TERMINOLOGY}

Anisotropy - a material hydraulic property the value of which varies with direction. For example, a fractured rock has a larger hydraulic conductivity in the directions of orientation of the fractures.

Aquifer - a saturated permeable geologic unit that transmits significant quantities of groundwater. The common definition is that an aquifer yields usable quantities of water to wells, but that definition is relaxed in this report (see Aquitard).

Aquitard - less permeable geologic units. In this report the term is used in contrast to aquifer, which contains more permeable flow networks.

Aquiclude - a saturated geologic unit that does not transmit significant quantities of water. Although the transmissive capabilities of the aquiclude on the ORR are poorly known, the term is used in this repon to denote the zone below active circulation.

Bathtubbing trench -- a burial trench partly or mostly filled with water. The water may overflow the trench and produce surface seeps.

Colloids - particles of $<10 \mu \mathrm{m}$ diam. suspended in water. Colloids such as iron oxyhydroxides and some clay particles can transport sorbed contaminants.

Conduit flow - flow in karst systems that occurs in pipelike openings created by solution of the matrix. Discharges from conduits typically are highly variable in time. Velocities can be as high as $500 \mathrm{~m} / \mathrm{h}$.

Connate water - water trapped in sediments at the time of deposition.

Cubic law - the equation that describes groundwater flow in an individual fracture: $\mathrm{Q}=\mathrm{KiA}=\frac{\rho \mathrm{g}(2 \mathrm{~b})^{3} \mathrm{Wi}}{12 \mu}$, where $K$ is hydraulic conductivity, $\rho$ is density of water, $g$ is the gravitational constant, $2 b$ is the full aperture, $W$ is fracture width, $A$ is the cross-sectional area through which flow occurs, $i$ is the hydraulic gradient, and $\mu$ is the viscosity of water. 
Diffuse flow - flow in karst systems that occurs primarily in the rock matrix. Flow rates are slower than in conduit flow and are less variable. Dissolved solids content of the water is less variable, and the water is less turbid than for conduit flow.

Diffusion - movement of solutes in the direction of their concentration gradient.

Discharge area - the portion of drainage basin in which the net flow of groundwater is upward, toward the water table.

Distribution coefficient - the ratio of the mass of solute on the solid phase per unit bulk dry mass of a porous medium over the concentration of solute. The distribution coefficient, or $\mathrm{Kd}$, is a measure of the sorption capacity of a material for a particular solute. For a fracture surface, the important ratio is the mass of solute on the solid phase per unit fracture area over the concentration in solution. See also Retardation factor.

DNAPLS - dense nonaqueous phase liquids (e.g., heavy weight organic chemicals, such as the solvent trichloroethylene). These liquids are denser and commonly have a lower viscosity than water. Because they have low solubility in water, they can form a separate mobile phase for which behavior is difficult to predict.

Flux - volume passing through a cross section per unit time.

Fractures, hydraulic properties of - properties that describe the capability of fractures to store and transmit water. Spacing, width, length, and orientation affect the interconnectivity of fractures. Aperture is the gap width of the fracture opening, but fracture walls may be smooth to rough and irregular.

Fracture flow model - a method of describing groundwater flow rates in fractures. Several approaches have been used: (1) Assume the system behaves as an equivalent por ous medium with a hydraulic conductivity higher than the unfractured system;

(2) Assume parallel plate fractures of infinite extent, with only diffusional solute movement in the matrix (nearly impermeable); (3) Assume discrete fractures of varying orientation and length in an impermeable matrix (network models); or (4) Assume discrete fractures in a permeable matrix (flow and transport in both the fractures and the matrix). 
Fracture formation - the relationship between stress and tensional strength of rocks leads to fractures.

Heterogeneous - a material property (such as hydraulic conductivity) whose value varies from location to location.

Homogeneous - a material property (such as hydraulic conductivity) whose vilue is constant at all locations.

Ion evolution sequence - tendency of chemical characteristics of groundwater to change in a sequence along a flow path, from dilute to highly mineralized water, based on mineral solubilities, flow rates, and time. An example from the ORR is the change from $\mathrm{CaHCO}_{3}$ type water to $\mathrm{NaHCO}_{3}$ type water.

Isotopes, natural $-{ }^{13} \mathrm{C},{ }^{14} \mathrm{C},{ }^{18} \mathrm{O},{ }^{2} \mathrm{H},{ }^{3} \mathrm{H},{ }^{34} \mathrm{~S}$, and ${ }^{15} \mathrm{~N}$ are isotopes present in groundwater because of natural processes and may provide a history of conditions and processes along the flow path. For example, the stable isotope 180 has been used to differentiate water recharged from an evaporated lake vs water recharged from precipitation. Natural ${ }^{3} \mathrm{H}$ is an indicator of young water since it is a stable isotope having a short half-life.

Isotropic - a material properny (such as hydraulic conductivity), the value of which is constant in every direction.

Karst - an irregular landscape most commonly underlain by carbonate rocks from which rock mass has been removed by dissolution. Surface features include sinkholes, disappearing streams, poorly defined drainage systems, and cavity springs.

$\mathbf{K d}$ - see Distribution coefficient.

Low permeability - a unit with a hydraulic conductivity of $<10^{-6} \mathrm{~cm} / \mathrm{s}$.

Macropores - voids $>1 \mathrm{~mm}$ in diameter. 
Major ions or constituents - solutes that together constitute $>95 \%$ of the total dissolved solids content. On the ORR, the major ions in the zone of active circulation are $\mathrm{Ca}, \mathrm{Mg}, \mathrm{Na}, \mathrm{HCO}_{3}$, and $\mathrm{SO}_{4}$.

Matrix diffusion - the process by which solutes can be transferred from fractures to the surrounding matrix by molecular diffusion. Although diffusion is slow, the concentration gradients can be large, and the storage capacity of the matrix may also be large.

Membrane filtration - the separation of chemical constituents in water moving through low permeability units because of ion charge or size.

Mesopores - voids $0.01-1 \mathrm{~mm}$ in diameter.

Micropores - voids $<0.01 \mathrm{~mm}$ in diameter.

Minor constituents - solutes that together constitute $<5 \%$ of the total dissolved solids and typically occur in concentrations of $<10 \mathrm{mg} / \mathrm{L}$.

Overburden - see Regolith.

Primary source - original contaminant mass, such as in a waste burial trench, liquid waste pond, or liquid waste spill.

Porosity - percentage of bulk rock or soil that is void space.

Matrix porosity - percentage of the bulk rock that is void space as opposed to fractures.

Effective porosity - percentage of bulk rock that consists of interconnected voids through which fluids can move.

Fracture porosity - percentage of the bulk rock that consists of fracture voids

Specific yield - percentage of the bulk rock that can be drained of water under the influence of gravity.

Regolith - all less cohesive materials above bedrock, either formed in place or transported. 
Recharge area - the portion of drainage basin in which the net flow of groundwater is downward.

Retardation factor - the relative rate of movement of a solute compared with that of a conservative (nonretarding) tracer.

Riparian zone - area along a river or other body of water.

Saprolite - weathered bedrock that has not been transported and that retains some of the original structure.

Secondary source - contaminant mass transported in the subsurface from a primary source and sorbed or stored in small pores in the matrix of materials along the flow path.

Source area - an area that prod"ces disproportionately large volumes of runoff, generally because of saturated conditions that result from collection of subsurface flow, a high water table, or very low permeability. Rainfall ponds on the surface and runs off rather than infiltrating.

Specific discharge - the rate of fluid flow per unit cross-sectional area; flux divided by the cross-sectional area.

Specific yield - see definition under Porosity.

Stormflow - transient, lateral saturated flow near land surface in the root zone of vegetation. Stormflow occurs after rainfall events.

Swallow hole - a depression into which a stream disappears underground, a common feature of karst areas.

Trace constituents - solutes that typically occur at concentrations $<0.1 \mathrm{mg} / \mathrm{L}$.

Velocity - the linear rate of fluid flow. Velocity can be measured directly from tracer tests or indirectly by dividing the specific discharge by the effective porosity. 


\section{REFERENCES}

Ashwood T. L., and B. P. Spalding. 1991. SWSA 6 interim corrective measures environmental monitoring: FY 1990 results. ORNL/ER-36. Oak Ridge National Laboratory.

Bailey, Z. C., and R. W. Lee. 1991. Hydrogeology and geochemistry in Bear Creek and Union Valleys, near Oak Ridge, Tennessee. U.S. Geological Survey Water Resouces Investigation Report 90-4088.

Bouwer, Herman. 1978. Groundwater Hydrology. McGraw-Hill, New Y'Jrk.

Bowen, Robert. 1986. Groundwater. 2d ed. Elsevier Science, New York.

Cassler, E. L. 1984. Diffusion mass transfer in fluid systems. Cambridge University Press, New York.

Connell, J. F., and Z. C. Bailey. 1989. Statistical and simulation analysis of hydraulic conductivity data for Bear Creek and Melton Valleys, Oak Ridge Reservation, Tennessee. U.S. Geological Survey Water-Resources Investigation Report 894062, Nashville, Tennessee.

Davis, E. C., W. J. Boegly, Jr., E. R. Rothschild, B. P. Spalding, N. D. Vaughan, C. S. Haase, D. D. Huff. S. Y. Lee, E. C. Walls, J. D. Newbold, and E. D. Smith. 1984. Site characterization techniques used at a low-level waste shallow land burial field demonstration facility. ORNL/TM-9146. Oak Ridge National Laboratory.

Davis, E. C., D. K. Solomon, R. B. Clapp, S. Y. Lee, P. M. Craig, A. D. Kelmers, and D. A. Lietzke. 1987. Summary of environmental characterization activities at the Oak Ridge National Laboratory Solid Waste Storage Area Six, FY 1986 through 1987. ORNL/RAP/LTR-87/68. Oak Ridge National Laboratory.

Davis, S. N., and R. J. M. De Wiest. 1966. Hydrogeology. John Wiley, New York.

de Laguna, W. T. Tamura, H. O. Weeren, E. G. Struxness, W. C. McClain, and R. C. Sexton. 1968. Engineering development of hydraulic fracturing as a method for permanent disposal of radioactive wastes. ORNL-4259. Oak Ridge National Laboratory.

Dreier, R. B., D. K. Solomon, and C. M. Beaudoin. 1987. Fracture characterization in the unsaturated zone of a shallow land burial facility. pp. 51-59. In Flow and Transport Through Fractured Rock. American Geophysical Union Monograph 42.

Dreier, R. B., and L. E. Toran. 1989. Hydrology of Melton Valley determined from hydraulic head measuring station data. ORNL/TM 11216. Oak Ridge National Laboratory.

Elmore, J. L., D. D. Huff, and J. R. Jones. 1984. West Chestnut Ridge hydrologic studies, ORNL/TM-9392. Oak Ridge National Laboratory.

Fetter, C. W. 1988. Applied Hydrogeology. Merrill Publishing, Columbus, Ohio. 
Freeze, R. A., and J. A. Cherry. 1979. Groundwater. Prentice-Hall, Englewood Cliffs, New Jersey.

Ford, D. C., and P. W. Williams. 1989. Karst Geomorphology and Hydrology. Unwin Hyman, Winchester, Massachusetts.

Genereux, D. P. 1991. Field studies of streamflow generation using natural and injected tracers on Bickford and Walker Branch Watersheds. Ph.D. thesis. Massachusetts Institute of Technology.

Geraghty \& Miller, Inc. 1989. Development of groundwater flow models for the S-3 Waste Management Area Y-12 Plant, Oak Ridge, Tennessee. Y-12 Report Y/SUB/89-00206C/1.

Gilham, R. W., and J. A. Cherry. 1982. Contaminant migration in saturated unconsolidated geologic deposits. pp. 31-62. In T. N. Narismhan (ed.), Recent Trends in Hydrogeology. Geological Society of America Special Publication 189.

Golder Associates Inc. 1987. Report on geohydrologic packer testing, Core Hole WOL-2. Golder Associates, Inc. Atlanta, Georgia.

Golder Associates Inc. 1987. Geoh ydrologic packer testing, GW-132, GW-133, GW-134, and GW-135, ORNL Y-12 Plant Area. Golder Associates, Inc. Atlanta, Georgia.

Haase, C. S., G. A. Gillis, and H. L. King. 1987. Groundwater investigation drilling program for Fiscal Year 1985 at the Y-12 Facility, Oak Ridge, Tennessee. ORNL/TM-9999. Oak Ridge National Laboratory.

Haase, C. S., G. A. Gillis, and H. L. King. 1987. Subsurface data base for Bear Creek Valley, Chestnut Ridge, and parts of Bethel Valley on the U.S. Department of Energy Oak Ridge Reservation. ORNL/TM-10000. Oak Ridge National Laboratory.

Haase, C. S., H. L. King, and G. A. Gillis. 1987. Preliminary hydrological and hydrochemical assessment of the Beta-4 Security Pit, Kerr Hollow Quarry, Ravine Disposal, Rogers Quarry, and United Nuclear Corporation sites at the Y-12 Plant, Oak Ridge, Tennesser. Y/TS-271.

Haase, C. S., J. Switek, and S. H. Stow. 1987. Geochemistry of formation waters in the lower Conasauga Group at the New Hydrofracture Facility: Preliminary data from the Deep Monitoring (DM) wells. ORNL/RAP-6. Oak Ridge National Laboratory.

Hatcher, R. D., R. B. Dreier, P. J. Lemiszke, R. R. Lee, R. H. Ketelle, W. M. McMaster, S. Y. Lee, D. A. Lietzke, and J. L. Foreman. 1992. Preliminary summary of the geology of the Oak Ridge Reservation. ORNL/TM 12074. Oak Ridge National Laboratory. 
Huff, D. D., G. S. Henderson, C. L. Begovich, R. J. Luxmoore, and J. R. Jones. 1977. The application of analytic and mechanistic hydrologic models to the study of Walker Branch Watershed. pp. 741-763. In D. L. Correll (ed.), Watershed Research in Eastern North America. Chesapeake Bay Center for Environmental Studies, Smithsonian Institution, Edgewater, Maryland.

Huff, D. D., J. L. Elmore, and D. C. Farmer. 1984. Hydrologic study and evaluation of Ish Creek Watershed (West Chestnut Ridge proposed disposal site). ORNL/TM-8960. Oak Ridge National Laboratory.

Huff, D. D., and B. J. Frederick. 1984. Hydrologic investigations in the vicinity of the proposed Central Waste Disposal Facility, Oak Ridge National Laboratory, Tennessee. ORNL/TM-9354. Oak Ridge National Laboratory.

Jacobs, G. K. 1989. The sedimentary rock program: A summary of the geochemical characteristics of shale important to waste isolation. ORNL/TM-10981. Oak Ridge National Laboratory.

Jardine, P. M., G. V. Wilson, and R. J. Luxmoore. 1990. Unsaturated solute transport through a forest soil during rain storm events. Geoderma 46:103-18.

Johnson, A. I. 1967. Specific yield-compilation of specific yields for various materials. U.S. Geological Survey Water-Supply Paper 1662-D.

Kearl, P. M., and T. A. Cronk. Laboratory observations and measurements of colloidal velocity in a monitoring well. Water Resour. Res.

Ketelle, R. H., and D. D. Huff. 1984. Site characterization of the West Chestnut Ridge site. ORNL/TM-9229. Oak Ridge National Laboratory.

King, H. L., and C. S. Haase. 1988. Summary of results and preliminary interpretation of hydrogeologic packer testing in core holes GW-131 through GW-135 and $\mathrm{CH}$ 157, Oak Ridge Y-12 Plant. Y/TS-495.

King, H. L., C. S. Haase, and B. K. Harrington. 1991. Updated subsurface data base for Bear Creek Valley, Chestnut Ridge, and parts of Bethel Valley on the U.S. Dept. of Energy Oak Ridge Reservation. Y/TS-735.

Lee, R. R., and R. H. Ketelle. 1988. Subsurface geology of the Chickamauga Group at Oak Ridge National Laboratory. ORNL/TM-10749. Oak Ridge National Laboratory.

Lee, R. R., R. H. Ketelle, J. M. Bownds, and T. A. Rizk. 1989. Calibration of a contaminant transport computer model: Progress toward model validation. ORNL/TM-11294. Oak Ridge National Laboratory.

Lemiszke, P. J. 1992. Fracture system characteristics of the Oak Ridge Reservation and possible controls on groundwater flow. Ph.D thesis, The University of Tennessee, Knoxville.

Lomenick, T. F., D. G. Jacobs, and E. G. Struxness. 1967. The behavior of strontium90 and cesium-137 in seepage pits at ORNL. Health Phys. 13:897-905. 
Lomenick, T. F., and H. J. Wyrick. 1965. Geohydrological evaluation of Solid Waste Storage Area 6. ORNL/TM-1327. Oak Ridge National Laboratory.

Lozier, W. B., and R. Pearson. 1987. Installation of packers and hydraulic testing of Core Holes $\mathrm{CH}-1$ through $\mathrm{CH}-5$, ORNL Plant Area, Vol. 1 of 2. Golder Associates, Inc. ORNL/Sub/86-32136/3/V1.

Luxmoore, R. J., B. P. Spalding, and I. M. Munro. 1981. Areal variation and chernical modification of weathered shale infiltration characteristics. Soil Sci. Soc. Am. J. 45(4):687-691.

Luxmoore, R. J., P. M. Jardine, G. V. Wilson, J. R. Jones, and L. W. Zelazny. 1990. Physical and chemical controls of preferred path flow through a forested hillslope. Geoderma 46:139-54.

McMaster, W. M. 1962. Geologic map of the Oak Ridge area, Tennessee. U.S. Atomic Energy Commission.

McMaster, W. M. 1963. [Report on] geologic map of the Oak Ridge Reservation, Tennessee. ORNL/TM-713. Oak Ridge National Laboratory.

McMaster, W. M. 1967. Hydrologic data for the Oak Ridge area, Tennessee. U.S. Geological Survey Water-Supply Paper 1839-N.

McMaster, W. M., and H. D. Waller. 1965. Geology and soils of the Whiteoak Creek basin, Tennessee. ORNL/TM-1108. Oak Ridge National Laboratory.

Melroy, L. A. 1986. Wet-weather dye tracer study. ORNL/RAP/LTR-86/42. Oak Ridge National Laboratory.

Meyer, R. E., W. D. Arnold, P. C. Ho, F. I. Case, and G. D. O'Kelley. 1987. Geochemical behavior of $\mathrm{Cs}, \mathrm{Sr}, \mathrm{Tc}, \mathrm{Np}$, and $\mathrm{U}$ in saline groundwaters: Sorption experiments on shales and their clay mineral components. ORNL/TM-10634. Oak Ridge National Laboratory.

Moore, G. K. 1992. Hydrograph Analysis in a Fractured Rock Terrane. ORNL/ER-45. Oak Ridge National Laboratory.

Moore, G. K. 1988. Concepts of groundwater occurrence and flow near Oak Ridge National Laboratory, Tennessee. ORNL/TM-10969. Oak Ridge National Laboratory.

Moore, G. K. 1989. Groundwater parameters and flow systems near Oak Ridge National Laboratory, Tennessee. ORNL/TM-11368. Oak Ridge National Laboratory.

Moore, G. K., D. D. Huff, and R. H. Ketelle. 1987. FY 1987 piezometer well data summary. ORNL/RAP/LTR-87/80. Oak Ridge National Laboratory.

Mulholland, P. J., G. V. Wilson, and P. M. Jardine. 1990. Hydrogeochemical response of a forested watershed to storms: Effects of preferential flow along shallow and deep pathways. Water Resour. Res. 26(12): 3021-36. 
National Oceanic and Atmospheric Administration. 1974. Tennessee. pp. 370-84. In Climates of the States, Vol. I-Eastern States. Water Information Center, Port Washington, New York.

Olsen, C. R., P. D. Lowry, S. Y. Lee, I. L. Larsen, and N. H. Cutshall. 1983. Chemical, geological, and hydrolo gical factors goveming radionuclide migration from a formerly used seepage trench. ORNL/TM-8839. Oak Ridge National Laboratory.

Peters, L. N., D. F. Grigal, J. W. Curlin, and W. J. Selvidge. 1970. Chemical, physical, and morphological properties of the soils of Walker Branch Watershed. ORNL/TM-2968. Oak Ridge National Laboratory.

Poreda, R. J., T. E. Cerling, and D. K. Solomon. 1988. Tritium and helium isotopes as hydrologic tracers in a shallow unconfined aquifer. J. Hydrol. 103:1-9.

Quinlan, J. F. 1989. Ground-water monitoring in karst terranes: Recommended protocols and implicit assumptions. EPA 600/x-89/050. U.S. Environmental Protection Agency Environmental Monitoring Systems Laboratory, Las Vegas, Nevada.

Rothschild, E. R., D. D. Huff, C. S. Haase, R. B. Clapp, B. P. Spalding, C. D. Farmer, and N. D. Farrow. 1984. Geohydrologic characterization of proposed Solid Waste Storage Area 7. ORNL/TM-9314. Oak Ridge National Laboratory.

Sledz, J. J., and D. D. Huff. 1981. Computer model for determining fracture porosity and permeability in the Conasauga Group. ORNL/TM-7695. Oak Ridge National Laboratory.

Smith, E. D., and N. D. Vaughan. 1985. Aquifer test analysis in nonradial flow regimes: A case study. Ground Water 23(2):167-75.

Snow, D. T. 1968. Rock fracture spacings, openings, and porosities. J. Soil Mech. Found. Div., Proceedings, American Society of Civi! Engineers 94:73-91.

Snow, D. T. 1969. Anisotropic permeability of fractured media. Water Resour. Res. 5(6):1273-89.

Solomon, D. K., and J. Switek. 1986. Trench-water d namics in SWSA 6: Methods and preliminary observations. ORNL/RAP/LTR-86/67. Oak Ridge National Laboratory.

Solomon, D. K., J. D. Marsh, D. S. Wickliff, I. L. Larsen, and R. B. Clapp. 1991. Transport of contaminarts during storms in the White Oak Creek and Melton Branch watersheds. ORNL/TM-11360. Oak Ridge National Laboratory.

Solomon, D. K., and G. T. Yeh. 1987. Application of 3DFEMWATER to the study of trench "bathtubbing." ORNL/RAP/LTR-87/89. Oak Ridge National Laboratory.

Spalding, B. P., and S. Y. Lee. 1987. In situ grouting of buried transuranic waste with polyacrylamide. In 1987 Oak Ridge Model Conference Proceedings, Vol. 1, Pt. 3. Martin Marietta Energy Systems, Inc., Oak Ridge, Tennessee. 
Stockdale, P. B. 19's1. Geologic conditions at the Oak Ridge (X-10) area relevant to the disposal of radioactive waste. ORO-58. U.S. Atomic Energy Comnission, Oak Ridge Operations, Oak Ridge, Tennessee.

Swank, W. T., and D. A. Crossley, Jr. (exti.). 1988. Forest Hydrology and Ecology at Coweeta [Hydrologic Laboratory, U.S. Forest Service, Otto, North Carolina]. Springer-Verlag, New York.

Switek, J., C. S. Hatase, and S. H. Stow 1987. Geochemistry of formation waters in the lower Conasauga Group at the New Hydrofracture Facility: Preliminary data from the Rock Cover (RC) wells. ORNL/RAP-5. Oak Ridge National Laboratory.

Tennessee Division of Water Resources. 1961. Tennessee's Waier Pesources. Tennessee Department of Conservation and Commerce, Nashville.

Tcrisi, L. E., D. K. Solomon, W. M. McMaster, and C. M. Morrissey. 1991. Matrix diffusion as a mechanism to explain recent tritium and old ${ }^{14} \mathrm{C}$ in groundwater from fractured sedimentary rock. EOS Trans. $72(17): 1: 1$.

Tucci, P. 1986. Ground water flow in Mlton Valley, Oak Ridge Reservation, Roane County, T"ennessee-preliminary model analysis. U.S. Geological Survey Water Resources Investigation Report 85-4221.

U.S. Environmental Protection Agency. 1986. RCRA ground-water monitoring technical enforcement guidance document. OSWER-9950.1. U.S. Environmental Protection Agency, Office of Solid Waste and Emergency Response, Washington, D.C.

Watson, K. W., and R. J. Luxmoore. 1986. Estimating macroporosity in a forest watershed by use of a tension infiltrometer. Soil Sci. Soc. Am. J. 50:578-82.

Webster, D. A. 1976. A review of hydrologic and geologic conditions related to radinacive solid-waste burial grounds at Oak Ridge National Laboratory, Ter nessee. U.S. Geological Survey Open-File Report 76-727, Nashville.

Webster, D. A., and M. W. Bradley, 1987. Hydrology of the Melton Valley radioactivewaste burial grounds at Oak Ridge National Laboratory, Tennessee. U.S. Geological Survey Open-File Report 87-686, Nashville, Tennessee.

Wickliff, D. 3., S. M. Gregory, I. L. Larsen, and R. B. Clapp. 1989. Contaminant transport during storms near solid waste storage areas 4 and 5. ORNL/R.AP/LTR89/20. Oak Ridge National Laboratory.

Wickliff, D. S., D. K. Solomon, and N. D. Farrow. 1991. Preliminary investigation of processes that effect source term identification. ORNL/ER-59. Oak Ridge National Laboratory.

Wilson, G. V., and R. J. Luxmoore. 1988. Infiltration, macroporosity, and mesoporosity distributions on two forested watersheds. Soil Sci. Soc. Am. J. 52(2):329-35.

Wilson, G. V., P. M. Jardine, R. J. Luxmoore, and J. R. Jones, 1990. Hydrology of a forested watershed during storm events. Geoderma 46:119-38. 
Witherspoon, P. A., J. S. Y. Wang, K. Iwai, and J. E. Gale. 1980. Validity of cubic law for fluid flow in a dermable rock fracture. Water Resour. Res. 16(6):1016-24\%

Young, 'S. C., H. S. Pearson, G. K. Moore, and R. B. Ciapp. 1991. Application of the electromagnetic borehole flowmeter technique at the Oak Ridge National Laboratory. WR28-1-900-247. Tennessee Valley Authority. 


\section{Internal Distribution}

1. T. L. Ashwood

2. L. D. Bates

3. F. P. Baxter

4. D. M. Borders

5. H.i. Boston

6. J. W. Bownds

7. H. M. Braunstein

8. J. B. Cannon

9. R. B. Clapp

10. K. W. Cook.

11. T. K. Cotiron

12. N. H. Cutshall

13. J. H. Cushman

14. M. F. P. DeLozier

15-19. R. B. Dreier

20. T. O. Early

21. T. A. Fonlaine

22. I. M. Forstrom

23. C. W. Fraricis

24. D. W. Frazier

25. B. J. Frederick

26. D. E. Fowler

27. S. B. Garland, II

28. C. W. Gehrs

29. P. L. Goddard

30. B. K. Harrington

31. R. D. Hzcher

32. S. G. Hildebrand

33. Lucius Holder, Jr.

34-53 D. D. Hulf

54. G. K. Jacobs

55. S. B. Jones

56. P. M. Jardine

57. P. Kanciruk

58. R. H. Ketelle

59. B. L. Kimmel

60. A. J. Kuhaida

61. R. R. Lee

62. S. Y. Lee

63. P. J. Lemiszke

64. R. S. Loffman

65. R. J. Luxmoore

66. L. W. McMahon
67-86. W. M. McMaster

87. C. M. Morrissey

88-107. G. K. Moore

108. P. J. Mulholland

109. J. B. Murphy

110. C. E. Nix

111. M. J. Norris

112. J. E. Nyquis.

113. F. S. Patton, Jr.

114. T. Purucker

115. D. E. Reichle

116. O. M. Reyes

117. C. T. Rightmire

118. M. W. Rosenthal

119. T. H. Row

120. P. A. Rubin

121. W. E. Sanford

122. F. E. Sharples

123. L. A. Shevenell

124. L. G. Shipe

125. R. L. Siegrist

126. D. S. Shriner

127. E. D. Smith

1:8-147. D. K. Solomon

148. B. P. Spalding

149. S. H. Stow

150. D.W. Swindle

151. M. F. Tardiff

15\%-171. L. E. Toran

172. J.R. Trabalka

173. J. E. Van Cleve

174. R. I. Van Hook

175. J.C. Wang

176. D. R. Walkins

177. R. K. White

178. D. S. Wickliff

179. T. F. Zondlo

180. Central Rescarch Library

181-195. ESD Library

196. ORNL Y-12 Technical Library

197-198 Laboratory Records Department

199. Laboratory Rercords, ORNL-RC

20). ORNL Putent Office

\section{External Distribution}

201. Jerry Archer, Geraghty and Miller Inc., 255 S. Tulane Ave, Oak Ridge, TN 37830

202. Richard Arnscth, SAIC, 301 Laboratory Road, Oak Ridge, TN 37830

203. Ernest Beauchamp, C-260 Jackson Plaza, MS 7614, Room 13, Oak Ridgc, TN 37830

204. Robert Benficld, TDEC/DOE Oversight, 761 Emory Valley Road, Oak Ridge, TN 37830 
205. G. W. Bodenstein, USDOE-OR, Federal Bldg, Oak Ridge, TN 37830

206. CH2M Hill Company, Office Manager, Oak Ridge

207. Paul Craig, Environmental Consulting Engineers, P.O. Box 22668, Knoxville, TN 37933

208. S. N. Davis, 6540 Box Canyon Drive, Tucson, AZ 85745

209. R. N. Farvolden, Waterloo Centre for Groundwater Research, University of Waterioo, Waterloo, Ontario N2L 361 Canada

210. J. F. Franklin, Bloedel Professor of Ecosystem Analysis, College of Forest Resources, University of Washington, Anderson Hall AR-10, Seattle, WA 98195

211. C. S. Haase, 603 School of Mines Road, Socorro, NM 87801

212. Jim Harless, TDEC/DOE Oversight, 761 Emory Valley Road, Oak Ridge, TN 37830

213. R. C. Harriss, Institute for the Study of Earth, Oceans, and Space, Science, and Engineering Research Building, University of New Hampshire, Durham. NH (03824

214. G. M. Hornberger, Professor, Department of Environmental Sciences, University of Virginia, Charlottesville, VA 22903

215. G. Y. Jordy, Director, Office of Program Analysis, Office of Energy Rescarch, ER-30, G-226, USDOE, Washington, DC 20545

216. Philip E. Lamoreaux and Associates, Inc., P. O. Box 2310, Tuscaloosa, AL 35403

217. R. Nativ, Department of Soil/Water Sciences, Faculty of Agriculture, Hebrew University of Jerusalem, P. O. Box 12, Rehovot 76100 Israel

218. Chudi Nwangwa, TDEC/DOE Oversight, 761 Emory Valley Road, Oak Ridge, TN 37830

219. Albert E. Ogden, Center for Management, Utilization and Protection of Water Resources, Tennessee Technological University, P. O. Box 5()82, Cookeville, TN 38505

220. R. H. Olsen, Professor, Microbiology and Immunology Department, University of Michigan, Medical Sciences II, \#5605, 1301 East Catherine Street, Ann Arbor, MI 48109-0620

221. A. Patrinos, Acting Director, Environmental Sciences Div., Ofc of Health and Environmental Research, ER-74, USDOE, Washington, DC 20585

222. James F. Quinlan, Quinlan and Associates, Box 110539, Nashville, TN 37222

223. Fred Quinones, Chief, Tennessee District, WRD, U. S. Geological Survey, A-413 Federal BIdg, Nashville, TN 37203

224. Radian/Lec Wan Associates, Office Manager, 120 S. Jefferson Circle, Oak Ridge, TN 37830

225. Gregory D. Reed, Chairman, Department of Civil Enginecring, University of Tennessec, 62 Perkins Hall, Knoxville, TN 37996-2010

226. Debra Shults, Tennessec Division of Environment and Conservation, Division of Radiological Health, TERRA Bldg., 150 Ninth Ave., North, Nashville, TN. 37243-1532. 
227. William C. Sidle, USDOE-OR, Environmental Protection Division, USDOE-OR, P.O. Box 2001,Oak Ridge, TN 37831-8739

228. James Smoot, Department of Civil Engineering, University of Tennessee, 62 Perkins Hall, Knoxville, TN 37996-2010

229. Systematic Management Services, Inc., Office Manager, 673 Emory Valley Road,

Oak Ridge, TN 37830

230. Jeff Walker, HSW Environmental Consultants, 687 Emory Valley Road, Suite B, Oak Ridge, TN 37830

231. Steven Wilson, TDEC, Division of Underground Storage Tanks, 27()0 Middlebrook Pike, Suite 220, Knoxville, TN 37921

232. S. L. Winters, 105 E. Price Road, Oak Ridge, TN 37830

233. F. J. Wobber, Environmental Sciences Division, Office of Health and Environmental Research, Office of Energy Research, ER-74, USDOE, Washington, DC 20585

234. John Young, Camp Dresser \& McKec, Suite 5()(), 8()() Oak Ridge Turnpike, Oak Ridge, TN 37830

235. Steven C. Young, TVA Engineering Laboratory, P. O. Box E, Norris, T'N 37828

236. Office of Assistant Manager for Energy Research and Development, U. S. Department of Energy Oak Ridge Ficld Office, P.O. Box 2001, Oak Ridge, TN 37831-86()0)

237-246. Office of Scientific and Technical Information, P.O. Box 62, Oak Ridge, TN 37831 

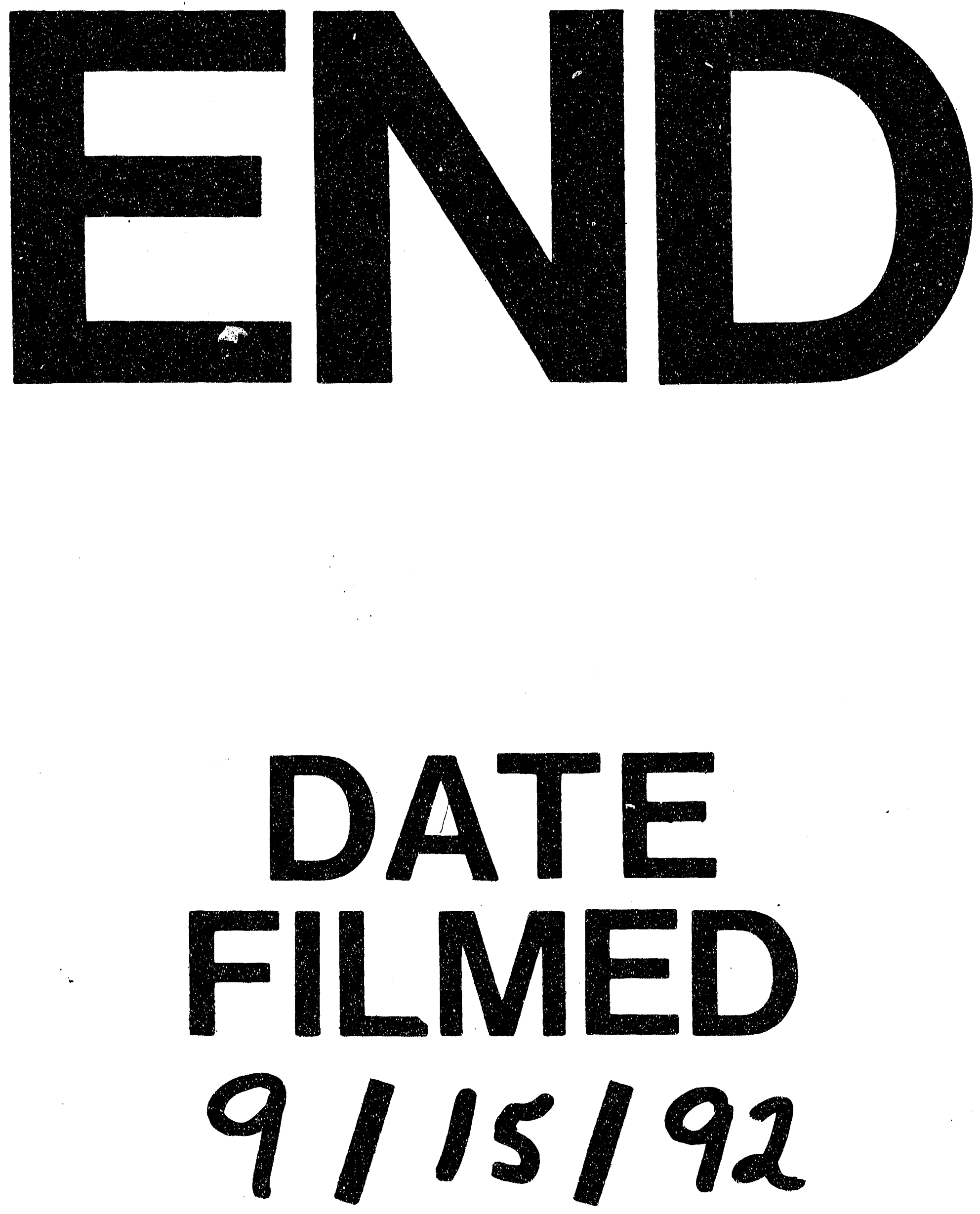

I 
